OECDpublishing

EMPLOYEE TRAINING AND FIRM PERFORMANCE: EVIDENCE FROM ESF GRANT APPLICATIONS

PEDRO S. MARTINS

OECD PRODUCTIVITY WORKING PAPERS

July 2021 No. 23 


\section{OECD PRODUCTIVITY WORKING PAPERS}

The OECD Productivity Working Papers are associated with the Global Forum on Productivity that provides a forum for mutual exchange of information and fosters international co-operation between public bodies with responsibility for promoting productivity-enhancing policies, including in undertaking joint policy analysis. It offers a platform for exchanging views, experiences and information, institutional and governance arrangements and government structures, with a view towards developing better policies. The Forum extends existing work in the OECD through a well-prioritised and coherent stream of analytical work serving the policy research needs of participants on the drivers of productivity growth.

This paper has been authorised for publication by Luiz de Mello, Director, Policy Studies Branch, Economics Department, Álvaro Santos Pereira, Director, Country Studies Branch, Economics Department, and Andrew Wyckoff, Director, Directorate for Science, Technology and Innovation.

OECD Productivity Working Papers should not be reported as representing the official views of the OECD or of its member countries. The opinions expressed and arguments employed are those of the author(s).

Comments on OECD Productivity Working Papers are welcome and may be sent to: productivity@oecd.org OECD Productivity Working Papers are published on: oe.cd/productivity

Series: OECD Productivity Working Paper Series

ISSN 2413-9424

Please cite this paper as:

Martins, Pedro S., "Employee Training and Firm Performance: Evidence from ESF grant applications", OECD Productivity Working Papers, 2021-23, OECD Publishing, Paris.

This document and any map included herein are without prejudice to the status of or sovereignty over any territory, to the delimitation of international frontiers and boundaries and to the name of any territory, city or area.

You can copy, download or print OECD content for your own use, and you can include excerpts from OECD publications, databases and multimedia products in your own documents, presentations, blogs, websites and teaching materials, provided that suitable acknowledgment of OECD as source and copyright owner is given. All requests for commercial use and translation rights should be submitted to PubRights@oecd.org. 


\section{ABSTRACT/RÉSUMÉ}

\section{Employee Training and Firm Performance: Evidence from ESF grant applications}

As work changes, firm-provided training may become more relevant. However, there is little causal evidence about the effects of training on firms. This paper studies a large training grants programme in Portugal, supported by the European Social Fund, contrasting firms that received the grants and firms that also applied but were unsuccessful. Combining several rich data sets, we compare many potential outcomes of these firms, while following them over several years both before and after the grant decision. Our difference-in-differences models estimate significant positive effects on take up (training hours and expenditure), with limited deadweight; and that such additional training led to increased sales, value added, employment, productivity, and exports (although not profits). These effects tend to be of at least $5 \%$ and, in some cases, $10 \%$ or more, and are robust in multiple dimensions.

JEL classification codes: J24, H43, M53

Keywords: Training subsidies, Productivity, Programme evaluation

Formation des salariés et performances des entreprises : enseignements tirés de demandes de subventions financées par le Fonds social européen (FSE)

Compte tenu de l'accélération du rythme auquel évolue le travail, il est possible que l'utilité des formations dispensées par les entreprises se renforce. Les éléments attestant l'existence d'un lien causalité entre la formation et le fonctionnement des entreprises sont néanmoins des plus limités. Nous étudions dans ce document un vaste programme de subventions à la formation mis en œuvre au Portugal avec le soutien du Fonds social européen (FSE), en mettant en regard les entreprises ayant obtenu des subventions et celles dont les demandes ont été rejetées. En combinant plusieurs ensembles de données volumineux, nous comparons un grand nombre de résultats potentiels de ces entreprises, tout en les suivant sur une période de plusieurs années, aussi bien avant qu'après la décision relative à leur demande de subvention. À l'aide de nos modèles de doubles différences, nous estimons des effets positifs significatifs sur le recours à la formation (nombre d'heures et dépenses de formation), accompagnés d'effets d'aubaine limités ; et nous parvenons à la conclusion que cette activité de formation supplémentaire s'est traduite par une augmentation du chiffre d'affaires, de la valeur ajoutée, de l'emploi, de la productivité et des exportations (mais pas des bénéfices). Ces effets tendent à être d'au moins $5 \%$, et peuvent atteindre dans certains cas $10 \%$ ou plus, et ils sont robustes dans de multiples dimensions.

Classification JEL : J24, H43, M53

Mots-clés : subventions à la formation, productivité, évaluation de programme 


\section{Table of contents}

Employee Training and Firm Performance: Evidence from ESF grant applications

1. Introduction

2. The FIG programme

3. Data

3.1. Descriptive statistics

4. Methodology

5. Main results

5.1. Training outcomes

5.2. Firm performance outcomes

6. Additional results $\quad 27$

6.1. Other outcomes

6.2. Different subsamples $\quad 28$

6.3. Heterogeneity analysis $\quad 30$

7. Concluding remarks 31

References 33

Annex A. Supplementary Figures and Tables $\quad 35$

\section{Tables}

Table 1. Descriptive statistics, All applicants, Application year (1/2) 10

Table 2. Descriptive statistics, All applicants, Application year (2/2) 11

Table 3. Training effects, 2010 and 2011, 2010 call, Different types (1/2) 17

Table 4. Training effects, 2010 and 2011, 2010 call, Workers and Expenditure (2/2) 19

Table A.1. Funding thresholds (marks out of 100), years, applicants and amounts 62

Table A.2. Descriptive statistics, application year, 2010 call only 63

$\begin{array}{lr}\text { Table A.3. Descriptive statistics, full sample } & 64\end{array}$

Table A.4. Regression results (1/2) $\quad 65$

Table A.5. Regression results (2/2) $\quad 66$

$\begin{array}{lr}\text { Table A.6. Multiple testing analysis } 1 / 2 & 67\end{array}$

Table A.7. Multiple testing analysis 1/2 68

Table A.8. Descriptive statistics, All successful applicants, Application year (1/2) 69

Table A.9. Descriptive statistics, All successful applicants, Application year (2/2) 70

\section{Figures}

Figure 1. DID effects: Log non-salary staff expenditure 15

Figure 2. DID effects - Training expenditure, 2010 and 2011 calls, 2010-2017 16

Figure 3. DID effects: Log sales 20 
Figure 4. DID effects: Log gross value added 21

Figure 5. DID effects: Export status $\quad 22$

Figure 6. DID effects: Log exports volume $\quad 22$

Figure 7. DID effects: Log number of employees $\quad 23$

Figure 8. DID effects: Log sales per worker 24

Figure 9. DID effects: Investment, profits and taxes $\quad 25$

Figure 10. DID effects - Firms within 2.5 points of funding threshold 26

Figure A.1. Probability of treatment and number of observations by (centred) application score 35

Figure A.2. McCrary density analysis $\quad 36$

Figure A.3. DID effects: Log non-salary staff expenditure per worker $\quad 37$

Figure A.4. DID effects: Log sales (alternative measure) 38

Figure A.5. DID effects: Log gross value added per worker $\quad 39$

Figure A.6. DID effects: Job and worker flows $\quad 40$

Figure A.7. DID effects: Worker characteristics $\quad 41$

Figure A.8. DID effects: Wages $\quad 42$

Figure A.9. DID effects: Firm's entry and exit $\quad 43$

Figure A.10. DID effects: 2007 call 44

Figure A.11. DID effects: 2008 call $\quad 45$

$\begin{array}{lr}\text { Figure A.12. DID effects: } 2009 \text { call } & 46\end{array}$

Figure A.13. DID effects: 2010 call $\quad 47$

Figure A.14. DID effects: 2011 call $\quad 48$

Figure A.15. DID effects: Firms present in all years $\quad 49$

Figure A.16. DID effects: Firms not present in all years 5

Figure A.17. DID effects: Control group of firms that declined funding 51

Figure A.18. DID effects - Firms within 5 points of funding threshold 52

Figure A.19. DID effects - Firms outside 2.5 points of funding threshold 53

Figure A.20. DID effects - Excluding firms that are rejected more than once 54

Figure A.21. DID effects - Heterogeneity: Manufacturing (top) and services (bottom) firms only 55

Figure A.22. DID effects - Heterogeneity: Large firms (top) and smaller firms (bottom) firms only 56

Figure A.23. DID effects - Heterogeneity: High scoring threshold (top) and low scoring threshold (bottom) firms

only $\quad 57$

Figure A.24. DID effects - Heterogeneity: Exporters (top) and non-exporters (bottom) firms only 58

Figure A.25. DID effects - Heterogeneity: High-schooling (top) and low-schooling firms only 59

Figure A.26. DID effects - Heterogeneity: Older workforce (top) and younger workforce (bottom) firms only 60

Figure A.27. DID effects - Heterogeneity: High female share (top) and low female share (bottom) firms only 61 


\title{
Employee Training and Firm Performance: Evidence from ESF grant applications
}

\author{
By Pedro S. Martins ${ }^{1}$
}

\section{Introduction}

1. As technology evolves more rapidly, firm-provided employee training can play an increasingly important role. Training can update and extend the schooling qualifications of workers in their jobs and deliver important private and social benefits. The pandemic crisis may also represent an opportunity for firms to invest in the skills of their workers in the context of growing importance of remote work. However, employee training also faces several well-known obstacles. These include worker mobility, namely through poaching by other firms, and credit constraints for firms to fund the direct and indirect costs of training. Such obstacles can lead to sub-optimal levels of this type of human capital investment (Leuven 2005).

2. Even if the obstacles above can be addressed, firms may find it difficult to estimate the returns to their training activities. Training sessions may be more or less effective; and the relationship between human capital improvements and gains in productivity and sales may be difficult to establish, leading to uncertainty that can further discourage training. This point is further underlined by the fact that the academic literature on the firm-level returns to employee training has not yet drawn on experimental variation. All approaches adopted so far are based on assumptions about the production technology of firms (Almeida \& Carneiro 2009, Mehra et al. 2014, Konings \& Vanormelingen 2015), controls for firm heterogeneity, including firm fixed effects (Goux \& Maurin 2000, Barrett \& O'Connell 2001, Zwick 2006, Dostie 2018) or case studies of single or small numbers of firms (Krueger \& Rouse 1998, Lyons 2020). As stated in Fialho et al. (2019), 'it is very difficult to measure the returns to training [for employers] and very few studies have attempted to estimate it' (page 24). Brunello \& Wruuck (2020) also highlight this point

\footnotetext{
1The author is affiliated with Queen Mary University of London \& NovaSBE \& IZA \& GLO (Email: p.martins@qmul.ac.uk). The author would like to thank an anonymous referee, Cátia Batista, Erich Battistin, Pawel Bukowski, Luisa Cachola, Luis Catela Nunes, Li Dai, Miguel Ferreira, Bernd Fitzenberger, Judite Gonçalves, Steffen Hoernig, Beatrice D'Hombres, Sabrina Howell, Kevin Lang, Domingos Lopes, Sandra McNally, Paolo Paruolo, Susana Peralta, Sofia Pessoa e Costa, Arun Rai, Pedro Vicente and seminar/workshop participants at European Commission (Ispra), ECVET Congress (Bern), POPH (Lisbon), ISEG (Lisbon), London School of Economics (CVER), NovaSBE (Carcavelos) and OECD (Paris) for helpful discussions. The author would also like to thank the QMUL Seed corn fund for financial support, NovaSBE for its generous hospitality, Cátia João for research assistance, and the 'Human Potential' Operational Programme (POPH), the Ministry of the Economy and INE (Portugal) for data access. The views expressed in this paper are those of the author and do not necessarily reflect those of the OECD or its member countries.
} 
and argue that a 'more systematic assessment of the benefits [of training for firms] could contribute to explain the heterogeneity in training investment' (page 29). ${ }^{2}$

3. In contrast to the literature above, this paper is one of the first to provide quasi-experimental evidence on the effects of employee training on firm performance. The variation in training across firms that we use here is drawn from a large, 200 million euro training grants programme supported by the European Social Fund of the European Union. This programme, FIG, implemented in Portugal, supported the training of employees of different skill levels, from factory workers to managers, and in diverse areas, including innovation, marketing, and international trade (Bloom et al. 2021). FIG involved five annual calls between 2007 and 2011, all studied here, each one receiving applications from about 2,000 firms. As demand exceeded the funding available, less than half of the applicants were selected and funded, receiving a grant of about 30,000 euros on average.

4. Our analysis is based on matching the administrative data from all applicants in each call to a rich matched employer-employee panel. This allows us to follow both the funded and the rejected firms, using difference-in-differences (Lechner 2011), and drawing on a more comparable (self-selected) set of firms. We follow these firms over a period of up to ten years before their application and up to ten years after the funding was or was not awarded. (Our approach bears some similarity to Holzer et al. (1993), which studies a training programme in Michigan, and Howell (2017), which studies an R\&D programme in the US. See also Criscuolo et al. (2019) which studies the effects of an industrial policy in the UK, which can also include worker training components.) Moreover, we consider a very large number of potential firm level outcomes, all of which collected from the same compulsory surveys across firms and years, to provide a comprehensive analysis of the effects of training. Some of these variables have not been examined before in the training literature. We also examine the effects of training at different times over the business cycle, which strengthens the external validity of our findings.

5. Our findings indicate that, first, the training grants had a significant positive effect on training activities: both training expenditure and training hours more than double. This increase also involved limited deadweight loss: we estimate that at least $74 \%$ of the grant led to additional training and, under some assumptions, cannot rule out some form of crowd-in (whereby the increase in training exceeded the support provided by the programme). Our finding of limited deadweight contrasts with several studies (Leuven \& Oosterbeek 2004, Abramovsky et al. 2011, Schwerdt et al. 2012, Hidalgo et al. 2014) but certainly not all (Holzer et al. 1993, Goerlitz 2010). Our results may be driven by the format of the programme, which required an application by interested parties (where they made their cases about the relevance of the grant) and established levels of co-payment by firms that decreased with the generality of the skills provided.

6. Second, we find that the additional training driven by the programme led to economically and statistically significant improvements in several dimensions of firm performance. Sales, value added, employment, productivity, and exports increase in the firms that received the training grant compared to the control group of unsuccessful applicants. On the other hand, total (accounting) investment and profits appear to not be positively affected by training, although these variables are subject to measurement error. As to the variables that increase, the effects are typically of around $10 \%$, emerge one or two years after the grant is provided and the training is conducted, and in some cases remain in place for at least ten years. Interestingly, the employment effects we find tend to be stronger in periods of recession. This may

\footnotetext{
2 Note that, in contrast, the related literature on returns to training provided to unemployed individuals includes several experimental and quasi-experimental contributions (Card et al. 2010) including, very recently, novel analyses using machine learning methods (Cockx et al. 2020, Zimmert 2020). Another important related literature is about the (individual) wage (and employment) returns to training (Leuven \& Oosterbeek 2008, Brunello et al. 2012, Goerlitz \& Tamm 2016, Dauth 2016).
} 
correspond to a positive form of training 'lock-in', in contrast to the case of training programmes for the unemployed, which may reduce transitions to employment at least in the short-run.

7. The large and durable positive effects in several firm performance variables and the relatively low cost of the additional training indicate that there may be significant under provision of employee training. At the same time, the results highlight the potential of public programmes in addressing at least part of this under provision. Quasi-experimental evidence may also go some way in informing firms regarding the likely returns from training. Our results also contribute to the evaluation of the 100 billion European Social Fund (Becker et al. 2013), of which FIG was a small component, and towards the design and implementation of the new funding schemes currently under plan to alleviate the pandemic crisis.

8. The structure of the remaining of the paper is as follows: Section 2 describes the training programme evaluated here. Sections 3 presents the data sets used (and their descriptive statistics) and 4 discusses our methodology. Our main results are presented in Section 5 while a number of additional results are described in Section 6. Finally, Section 7 concludes.

\section{The FIG programme}

9. Our evidence on the returns to training is driven from a public programme that offered training grants to successful firms following an application process. This programme, FIG, was launched in Portugal in 2008 and was funded both by the European Social Fund (ESF) and the Government of Portugal. ${ }^{3} \mathrm{FIG}$, with a total budget of about 200 million euros, provided grants to support firms in the training of their employees, in particular in the context of technical, technological and organisational changes.

10. The funding was made available to firms depending on the scoring of their applications, which was conducted by the public agency responsible for the management of FIG (and other ESF programmes). The scoring was based on several criteria, each one carrying a specific weight. The main criterion (40\% weight) was about the extent to which the training would provide knowledge and skills to workers that were required given technical, technological, and organisational changes. The training would have to promote workers' employability, while 'fostering innovation and the production of higher-value added tradable goods and services'. ${ }^{3}$ The grant would range between $30 \%$ and $80 \%$ of total training costs, depending on training type, firm size and region. For instance, general training provided by small firms located in low average GDP regions would receive the highest subsidy rate. Eligible training costs could include also indirect costs (namely the salaries of the workers participating in training, during the period in which the training was taking place). On average, each grant was of about 30,000 euros, as we will see later when we describe our data.

11. Unlike other ESF programmes, FIG was demand-led, as the grants were given to firms and not training providers. ${ }^{4} \mathrm{FIG}$ also supported flexible training, including that of a practical nature (in the

3 FIG stands for Training for Innovation and Management ('Formacão para a Inovacão e a Gestão'). The European Social Fund supported several other similar programmes, including the 'New Innovative Entrepreneurship' (Greece), 'Professional qualifications and counselling for enterprises' (Poland), and the 'Training Aid Framework' in Malta. However, FIG was the only programme of its type in Portugal at the time under analysis. 3 The remaining criteria involved a focus on smaller firms (20\% weight), low-skill workers and certification (10\%), training what would increase promotions and quality of life (15\%), skills in new technologies (10\%), and the promotion of the equality of opportunities (namely in terms of gender; $5 \%$ ). It is important to note that some of these criteria, in particular the first one, inevitably involve some degree of subjectivity in the resulting evaluations carried out by the public agency.

4 In practice, many applications may have been intermediated by training providers, which tend to be more knowledgeable about training grants, including the application process, compared to the firms that formally submitted the application and whose employees receive the training. These training providers may also deliver the subsidised training later, in case the application is successful. FIG was the only demand-led programme at the time - the remaining 
workplace, not in a classroom, and during normal working hours) and based on contents outside the official training 'catalogue', a registry of all certified courses and modules. Training content from this catalogue tends to be more general (as opposed to firm specific) but sometimes is regarded to be outdated with respect to firm needs, in particular those firms that are more technologically advanced. Finally, according to its regulations, FIG funding could be used to meet (and exceed) the labour-law mandate in Portugal that firms provide their employees at least 35 hours of training per year. ${ }^{5}$

12. We study the first five annual calls for applications, between 2007 and 2011, each with a total budget of about 40 million euros. Each call was composed of three regional sub-calls (corresponding to regions of different GDP per capita levels and different grant rates). In all cases, applications had to meet a minimum threshold of 50 points (out of 100) or higher (if demand for funding at the minimum quality level exceeded the budget available). The deadline for the submission of applications in each call was around June (of year zero, in the terminology of our analysis below), while the funding results were released in September and the funding was provided for training that started from January of the following year (year one). The exception was the first, 2007 call that had a later deadline for submissions, release of results and start date. ${ }^{6}$

\section{Data}

13. Our empirical analysis is based on combining four different data sets. The first is an administrative and confidential data set made available by the FIG agency. This data set lists all firms that submitted applications to the five calls mentioned above, between 2007 and 2011. This data set also includes information about the score of each application as well as funding and training values requested to and provided by FIG.

14. The second data set is a matched employer-employee panel census, QP (Quadros de Pessoal or Personnel Records). This data set, administered by the Ministry of Employment, has been used extensively in different fields given its richness: it includes detailed firm- and worker-level information on all firms based in Portugal that employ at least one worker in (October of) each year. Some of the firm-level variables we use are annual sales, number of employees, industry, and region. At the worker level, QP provides information on several variables including age, gender, schooling, and wages (all regarding the workforce of the firm as of October of each year). Moreover, unique firm (and worker) identifiers allow researchers to conduct longitudinal analyses, as we do in this study. We consider the period between 2002 and 2017, including at least five years before FIG in all calls.

15. We also draw on a novel component of QP, introduced in 2010, about the training of employees conducted by each firm. This data set provides information on the hours of training of each worker of each firm in each year, broken down in terms of the provider of the training (the firm itself or a different organisation, such as a training provider), where the training was conducted (in or outside the firm) and

training programmes were supply-led, focused on supporting apprenticeships, traineeships and training directed to unemployed jobseekers.

5 According to the Labour Code, such 35 hours of minimum training per year can be deferred or anticipated by one year, so that they are made available over a period of three years on average. Firms can also opt to offer fewer training hours, but in this case employees are entitled to be paid for the hours in which they worked instead of receiving training.

6 The amount made available to each successful applicant could also be subject to discretionary downward adjustments by the agency managing FIG. See Table A.1 for more details regarding each call and Figure A.1 for the distribution of scores (centred in terms of the applicable threshold) and the resulting acceptance rates. 
the timing of the training (during working hours or at a different time). We have access to this data for both 2010 and 2011 but not more recent years. ${ }^{7}$

16. The third data set, SCIE, provides firm-level information on a large number of accounting and financial variables over the period 2004-2017. This data set covers all firms in the country and is compiled by Statistics Portugal. The variables available include gross added value, sales, investment, profits, and income taxes, all of which we use as potential outcomes. We also use a variable indicating the firm's annual expenditure on staff excluding salaries, which includes training costs, and a variable indicating expenditure on training. While the former variable is available since 2004 , the latter is only available from 2010, when FIG is running its fourth call.

17. Our fourth and last data set, $\mathrm{Cl}$, provides detailed firm-level information on the international trade of goods. We focus on the exports of each firm, considering their total value as well as the number of (eight-digit) products exported and the number of countries the firm exports those products to, over the period 2002-2017. Similarly to SCIE, CI is collected by Statistics Portugal and covers all firms in the country.

18. We constructed the data set that we use by merging the FIG admin data to the QP data set ensuring that the confidentiality of the firms was preserved. Moreover, the QP data (together with the FIG data) was merged to the SCIE and $\mathrm{Cl}$ data sets using common firm identifiers made available by Statistics Portugal. The final version of the data set used in our analysis thus covers the periods 2002-2017 (QP and Cl data), 2004-2017 (SCIE, except its training variable, available between 2010 and 2017) and 2010-2011 (individual-level training data). This data refers to the 9,386 different firms that applied to FIG over the 2007-2011 period. This time span allows us to measure their post-FIG outcomes over a period of between six (2012-2017) and ten years (2008-2017). This time coverage also allows us to compare their characteristics up to their applications to FIG over an equivalent period of between six (2002-2007) and ten years (2002-2011). In total, each firm can be followed over a period of up to 16 years (2002-2017).

19. Note that a small number of firms apply more than once. In this case, if firms apply multiple times but are always unsuccessful, we keep all their applications in our benchmark results. In our robustness section, we check that the results do not change when dropping these firms. If firms apply multiple times but are successful at least once, then we only keep in the data their first successful application. This may underestimate the total amount of the financial support received by some firms but ensures that firms are not placed in the control group or in the 'before' period when they may have already received a grant.

\subsection{Descriptive statistics}

20. Table 1 and Table 2 present descriptive statistics of our firms, separately for approved and rejected firms. The tables consider the characteristics of the firms only in the years of each call to which a firm applied (2007-2011), i.e., immediately before the FIG funding is made available in case of success (Table A.3 presents descriptive statistics for the full sample of 133,051 firm-year observations over the 2002-2017 period).

7 Other studies including QP data include Martins (2019), on the effects of trade union representatives on firm performance and the role of training, Martins \& Thomas (2021), which examines training and worker interfirm mobility also from a theoretical perspective, and Martins (2009), on firm performance effects of an employment law reform. Note that QP is also used in the monitoring of compliance with labour regulations by the labour inspectorate and firms are consequently subject to heavy fines if the information registered in QP is incorrect. 
Table 1. Descriptive statistics, All applicants, Application year (1/2)

\begin{tabular}{|c|c|c|c|c|c|c|}
\hline & \multicolumn{2}{|c|}{ (1) } & \multicolumn{2}{|c|}{ (2) } & \multicolumn{2}{|c|}{ (3) } \\
\hline & \multicolumn{2}{|c|}{ Approved } & \multicolumn{2}{|c|}{ Rejected } & \multicolumn{2}{|c|}{ Difference } \\
\hline & Mean & SD & Mean & SD & $b$ & $\mathrm{t}$ \\
\hline Total sales & 19.49 & 138.94 & 14.64 & 183.38 & -4.86 & $(-1.45)$ \\
\hline Number of employees & 111.66 & 480.61 & 109.44 & 603.76 & -2.21 & $(-0.20)$ \\
\hline Capital equity & 4.01 & 40.99 & 3.49 & 67.48 & -0.52 & $(-0.47)$ \\
\hline Domestic private share & 89.49 & 29.79 & 82.13 & 37.72 & $-7.35^{\star \star *}$ & $(-10.47)$ \\
\hline Foreign share & 6.57 & 23.83 & 4.89 & 20.81 & $-1.68^{\star \star \star}$ & $(-3.48)$ \\
\hline Firm age & 21.35 & 22.77 & 21.58 & 42.65 & 0.23 & $(0.34)$ \\
\hline Gross added value & 5.37 & 41.36 & 3.30 & 19.72 & $-2.07^{\star *}$ & $(-2.75)$ \\
\hline Total sales (2) & 19.76 & 112.57 & 15.22 & 157.01 & -4.54 & $(-1.55)$ \\
\hline Investment & 1.44 & 21.80 & 0.61 & 23.05 & -0.83 & $(-1.69)$ \\
\hline Profits & 0.88 & 13.68 & 0.43 & 11.36 & -0.46 & $(-1.62)$ \\
\hline Income taxes paid & 0.28 & 3.73 & 0.11 & 1.57 & $-0.17^{*}$ & $(-2.50)$ \\
\hline Non-salary staff expenditure & 0.66 & 4.74 & 0.46 & 2.20 & $-0.20^{*}$ & $(-2.32)$ \\
\hline Training expenditure & 4.98 & 30.49 & 4.03 & 29.01 & -0.96 & $(-1.02)$ \\
\hline Food & 0.05 & & 0.03 & & $-0.02^{* \star \star}$ & $(-4.49)$ \\
\hline Clothing & 0.04 & & 0.02 & & $-0.01^{* * *}$ & $(-3.74)$ \\
\hline Ceramics & 0.04 & & 0.02 & & $-0.02^{\star \star *}$ & $(-5.78)$ \\
\hline Molds & 0.07 & & 0.04 & & $-0.03^{\star \star *}$ & $(-5.86)$ \\
\hline Construction & 0.04 & & 0.05 & & 0.00 & $(0.92)$ \\
\hline Electric appliances & 0.04 & & 0.04 & & 0.00 & $(0.41)$ \\
\hline Wholesale & 0.11 & & 0.09 & & $-0.02^{* * *}$ & $(-3.67)$ \\
\hline Retail & 0.06 & & 0.07 & & $0.01^{* *}$ & $(2.83)$ \\
\hline Transport & 0.03 & & 0.03 & & -0.01 & $(-1.70)$ \\
\hline North region & 0.46 & & 0.42 & & $-0.04^{\star \star *}$ & $(-3.81)$ \\
\hline Centre region & 0.33 & & 0.34 & & 0.01 & $(1.39)$ \\
\hline Lisbon region & 0.13 & & 0.16 & & $0.03^{\star \star * *}$ & (3.66) \\
\hline Exports & 9.90 & 54.07 & 8.42 & 93.14 & -1.47 & $(-0.52)$ \\
\hline N. of products exported & 23.43 & 50.31 & 24.04 & 68.97 & 0.61 & $(0.27)$ \\
\hline N. of countries exported to & 8.17 & 10.82 & 6.20 & 9.08 & $-1.97^{\star \star *}$ & $(-5.34)$ \\
\hline Observations & 3581 & & 5805 & & 9386 & \\
\hline
\end{tabular}

Note: All statistics refer to the firms observed in the year before the funding starts in the call of the application (2007 to 2011). All monetary variables are measured in millions of 2017 euros, except training funding (thousands of 2017 euros) and salaries (2017 euros). Sales (exports) denotes the total sales (total sales abroad) over the year. Number of employees refers to the employment of the firm in October of the year (including fixed term contracts but not temporary work). Domestic private equity share is the percentage of total equity that is held by private domestic investors. Foreign share is the percentage of total equity that is held by foreign investors. N. of products (countries) exported is the number of products (countries) the firm exports (to) over the year. The first group of variables are obtained from the QP data set, the second from the SCIE data set, and the third from the $\mathrm{Cl}$ data set. 
Table 2. Descriptive statistics, All applicants, Application year (2/2)

\begin{tabular}{|c|c|c|c|c|c|c|}
\hline & \multicolumn{2}{|c|}{ (1) } & \multicolumn{2}{|c|}{ (2) } & \multicolumn{2}{|c|}{ (3) } \\
\hline & \multicolumn{2}{|c|}{ Approved } & \multicolumn{2}{|c|}{ Rejected } & \multicolumn{2}{|c|}{ Difference } \\
\hline & Mean & SD & Mean & SD & $b$ & $\mathrm{t}$ \\
\hline Employees' female share & 0.36 & 0.28 & 0.44 & 0.31 & $0.08^{* * *}$ & (12.92) \\
\hline Employees' age & 38.35 & 4.73 & 38.17 & 5.05 & -0.18 & $(-1.75)$ \\
\hline Employees' tenure & 7.58 & 5.15 & 6.79 & 6.10 & $-0.79^{\star \star \star}$ & $(-6.72)$ \\
\hline Employees' open-ended contract & 0.69 & 0.26 & 0.68 & 0.27 & -0.00 & $(-0.79)$ \\
\hline Employees' schooling & 9.04 & 2.29 & 9.76 & 2.75 & $0.72^{\star \star \star}$ & $(13.72)$ \\
\hline Employees' base wage & 810.85 & 421.55 & 817.77 & 695.53 & 6.92 & $(0.60)$ \\
\hline Employees' total wage & 952.32 & 473.77 & 946.30 & 733.92 & -6.01 & $(-0.48)$ \\
\hline Training funding requested & 96.80 & 278.35 & 78.23 & 182.06 & $-18.57^{\star \star \star}$ & $(-3.55)$ \\
\hline Training funding approved & 27.79 & 35.77 & 1.69 & 8.35 & $-26.10^{\star \star \star}$ & $(-42.95)$ \\
\hline Subsidy (wagebill) rate & 1.25 & 5.48 & 0.11 & 0.75 & $-1.14^{\star * *}$ & $(-12.41)$ \\
\hline Workers to train request & 130.57 & 189.92 & 159.39 & 275.83 & $28.82^{\star \star \star}$ & $(5.99)$ \\
\hline Workers to train approved & 111.81 & 140.05 & 0.00 & 0.00 & $-111.81^{\star \star \star}$ & $(-47.77)$ \\
\hline Training hours request & 3955.13 & 6690.82 & 4941.57 & 10781.12 & $986.44^{\star \star *}$ & $(5.47)$ \\
\hline Training hours approved & 3371.67 & 4173.90 & 0.00 & 0.00 & $-3371.67^{\star \star \star}$ & $(-48.34)$ \\
\hline Duration of training (months) & 11.39 & 6.79 & 10.74 & 5.19 & $-0.66^{\star * \star}$ & $(-4.96)$ \\
\hline Training hours (2011 \& 2011) & 1149.19 & 5589.43 & 1831.11 & 16018.37 & $681.92^{*}$ & (2.09) \\
\hline Non-catalogue training & 441.58 & 4941.42 & 947.88 & 12337.69 & 506.30 & (1.95) \\
\hline Externals-provided training & 674.97 & 2290.85 & 838.73 & 4910.47 & 163.76 & $(1.52)$ \\
\hline Working-time training & 965.94 & 5497.24 & 1606.61 & 15728.52 & $640.67^{\star}$ & $(2.00)$ \\
\hline Workers under training & 22.64 & 132.05 & 51.83 & 669.94 & $29.19^{* *}$ & (3.22) \\
\hline Observations & 3581 & & 5805 & & 9386 & \\
\hline
\end{tabular}

Note: See notes to Table 1. Tenure is measured in years with the firm. Schooling is measured in years. Wages are monthly. The first and third groups of variables are obtained from the QP data set, the second from FIG administrative data. The third group of variables refers to 2010 and 2011 only. Subsidy (wagebill) rate indicates the ratio between the total grant and the wagebill of the firm.

21. We find that the two groups of firms exhibit differences that are in several cases significant but certainly not always. Focusing first on the case of the means of approved firms (those that receive and use the training grants from FIG), we find that they have annual sales of $19 \mathrm{~m}$ euros, employ 112 workers, have capital equity of $4 \mathrm{~m}$ euros ( $89 \%$ of which held by domestic private investors), and have been operating for about 21 years. All monetary variables were converted to 2017 euros using the consumers' price index and are expressed in millions except training variables (in thousands of euros) and wages (in euros). ${ }^{8}$ Considering the average size of FIG-supported firms and their number as well as the total size of the workforce in the country (around $3 \mathrm{~m}$ individuals), we note that, over the five years analysed here, FIG supported firms that accounted for well over $10 \%$ of the private sector employment of the country.

8 Note that several variables exhibit a significant level of skewness, leading to means that can be much larger than the medians. For instance, the median firm size is 36. 
22. As to the means of the remaining variables, gross added value is $5.4 \mathrm{~m}$, investment is $1.44 \mathrm{~m}$, and profits are $0.88 \mathrm{~m}$. Non-salary staff expenditure - which may include a number of diverse items on top of training, such as subsidised meals, health and safety expenses, and recruitment and separation costs corresponds to $0.66 \mathrm{~m}$. In contrast, mean training expenditure (a variable available from 2010) is less than five thousand euros, around $1 \%$ of non-salary staff expenditure. ${ }^{9}$

23. Regarding their FIG applications, approved firms request means grants of 97k euros, while 28k are approved (median 19.2k). Again, in terms of means, these grants correspond to $125 \%$ of the monthly total wage bill of a firm (median 65\%). The number of worker participations in training (including attendance of multiple training modules by the same worker) ranged between 131 (request) and 112 (approved), while the number of training hours ranged between 3.95k (request) and 3.37k (approved) and were conducted over a period of 11 months. Considering the average number of workers per firm, the approved training hours figure amounts to a mean number of training per worker similar to the 35-hour figure established in labour law but would exceed it in the likely case that not all workers participate in FIG funded training. ${ }^{10}$

24. As to the observable differences between approved and rejected firms, in the year of their applications, the most important differences concern ownership (approved firms are more likely to be owned by private parties) and gross added value (higher for approved firms). There are also some differences in their sectoral distribution, more concentrated in the leading industries mentioned before in the case of approved firms. Their workforces are somewhat more male, have more tenure and less schooling. As to training, approved firms request and (of course) receive more funding from FIG. ${ }^{11}$

25. Note also that, considering the year of 2008 alone, while firms applying to FIG represent only $0.89 \%$ of all $357 \mathrm{k}$ firms with employees in the country, they account for $14.9 \%$ of all private sector employment and $16.3 \%$ of all sales in the private sector (figures from our analysis of population QP data). Applicant firms are also older (median year of foundation of 1992 as opposed to 1999 in the case of nonapplicants). The contrast between applicant and non-applicant firms in these different dimensions highlights the non-representative nature of the FIG firms in terms of the full economy and the potential limitations of the external validity of our findings below.

9 The most important industries include wholesale, moulds, retail and food (corresponding to over $5 \%$ of all firms each), while the North and Centre regions (with lower average GDP per capita and higher FIG subsidy rates) cover by far the largest percentage of firms (nearly $80 \%$ in total), given the focus of the ESF in less developed regions in the EU. Exports account for nearly $10 \mathrm{~m}$ euros and involve over 23 different products and eight destinations. As to the firms' workforce, $36 \%$ are women, they are 38 years old, have been with the firm for 7.5 years, $69 \%$ have open-ended (permanent) contracts, nine years of schooling and are paid 811 and 952 euros per month (base and total pay, respectively).

10 We also report descriptive statistics regarding individual-level training data that we aggregated to the firm-level, in this case concerning the years of 2010 and 2011 only (QP data set). We find that mean training hours per firm-year are $1.1 \mathrm{k}$, about one third of the training hours funded by FIG, or an average of about ten hours of training per worker per year. Less than half of total training is flexible (possibly firm-specific and non-certified) training content, while external organisations provide more than half, and nearly all is provided during working time. On average, only 22 workers (out of a mean of 112) receive training over the two years considered. Again, these figures on training intensity do not necessarily imply non-compliance with the labour law requirement of 35 hours of training per worker per year as firms may anticipate or delay this training requirement or pay the worker for the time that is not spent under training.

11 The amount approved in the case of rejected firms is not zero because a small number of firms drop out from FIG after having their application approved. We use these firms for additional robustness checks described below. However, approved firms request support for fewer workers and fewer hours of training. Importantly, actual training hours and workers under training in 2010 and 2011 (again, in the years in which they apply) are lower in approved firms. 


\section{Methodology}

26. This paper seeks to understand the effects of a training subsidy on a number of firm-level outcomes. We conduct a difference-in-differences (DiD) analysis (Lechner 2011) by comparing, over time, firms that apply for and receive the FIG training subsidy against firms that also apply but do not receive such financial support. Identification in this DiD context in predicated on a number of assumptions, namely common trends, but also several other such as stable unit treatment value, exogeneity of conditioning variables, bias stability, and common support. ${ }^{12}$

27. The common trend assumption establishes that differences over time in expected potential outcomes under non-treatment are unrelated to group membership (treatment or control). In our specific case, this assumption requires that, in the absence of treatment, subsidised firms would evolve over time in the same way as non-subsidised firms. This assumption is testable to the extent that our pre-treatment is informative enough regarding the relevant trends experienced by the firms. As indicated above, our data covers a period of between six and ten years before the relevant moment when the subsidy is or is not provided, a particularly large number of years. We also exploit this relatively large number of years to run 'placebo experiments' (analysing potential 'effects' before the subsidy was provided), which make the common trends assumption more plausible. A threat to identification would involve some form of changes in supported firms that take place just before the treatment starts and are not captured in the data available (more generally, there may have been time-varying unobserved differences between firms applying successfully or unsuccessfully). While we cannot rule this out entirely, we believe this would not apply in our case, given the comprehensive nature of our data, measuring training and other investments over the entire year, and the relatively long duration of time required by investment in physical and even human capital. For instance, training courses can require considerable planning (contents, formats, delivery, etc) and be delivered over many months or even one year.

28. As to the remaining identification assumptions, they are not testable to the extent that they depend on unobservable random variables. However, we believe stable unit treatment value would also apply in our case: despite the significant size of the firms supported, representing around $7 \%$ of employment and sales, we believe this figure would be large enough to induce effects on control group firms. As to exogeneity, we allow the programme to have multiple effects and therefore adopt a minimalistic equation, controlling only for time-invariant variables (industry, original firm size, original workforce profile, etc) through fixed effects. Indeed, we exploit our panel data to difference out all influences of time constant (additively separable) confounding factors. The large number of periods (and the many groups of observations) is also important as it allows more precise estimation and more reliable inference, on top of the testing for the common trend assumption (Lechner 2011). Common support is also strengthened through our analysis exclusively of firms that applied to the programme, while also considering different ranges of application scores in Section $6 .{ }^{13}$ Specifically, the model we consider is as follows:

12 Figure A.2 presents the McCrary (2008) analysis of this distribution. The analysis indicates that the distribution of scores is not continuous at the funding threshold thus discouraging a regression discontinuity approach. According to discussions with the FIG agency, the gap in the distribution at the left of the funding threshold may be driven by the re-analysis of a number of marginal applications, following complaints from such rejected candidates that were subsequently accepted. Our data does not indicate which firms had their scores revised upwards but we conduct a number of robustness checks around this margin and find that this does not affect our results.

13 See Murakozy \& Telegdy (2020) for a similar empirical approach, which also includes a theoretical discussion. This discussion involves a linkage between a technology upgrading and TFP growth, that may apply the case of FIG as well, in which subsidies may lead to improvements in capital, output and labour productivity growth and ambiguous employment effects. 


$$
Y_{i t j}=\sum_{j=-9}^{10} \delta_{j} I(t ; j)+\sum_{j=-9}^{10} \beta_{j} F I G_{i} * I(t ; j)+\alpha_{i}+\tau_{t}+\epsilon_{i t j}
$$

29. in which $Y_{i j j}$ is the log of a given outcome of firm $i$ in calendar year $t$ and relative year $j$ (the latter defined in relation to the call year in which firm i applied to $F I G)$. FIGi is the treatment dummy variable (equal to one in the case of firms that received FIG funding).

30. The relative year period ranges between -9 (the year 2002 for firms that applied to the 2011 call) or -7 (in the case of the SCIE variables, which are available from 2004) and +10 (the year 2017 for firms that applied to the 2007 call, which have an 'after' period of ten years). The relative year 0 (which is also the benchmark year) corresponds to $2007,2008,2009,2010$ or 2011, depending on the call in which firm $i$ submitted its application. $I(t ; j)$ is a dummy variable equal to one when year $t$ corresponds to year $j$ (for instance, $I(t ; j)=1$ for all firms that apply to the 2008 call when they are observed in year 2008). The $\tau_{t}$ parameters thus capture systematic differences in the underpinning calendar years (2002-2017) and the $\alpha_{i}$ (the firm fixed effects) control for time-invariant differences of each firm. Critically, the $\delta_{j}$ pick up differences in the relative years -9 to +10 (with respect to the year of each call).

31. Finally, the key parameters of interest are the $\beta_{j}$, which indicate any systematic differences in $Y_{i j}$ at each relative year between firms that receive FIG funding and those that do not. In the context of the identification discussion above, $\beta_{j}$ will indicate the average treatment effect on the treated. As we consider several outcome variables of interest measured over long periods, we present most of our results graphically, focusing on the point estimate of each $\beta_{j}$ parameter and its $95 \%$ confidence interval, based on standard errors clustered at the firm level. In the appendix, we also present the full regression results for the key variables of interest.

\section{Main results}

\subsection{Training outcomes}

32. Our first analysis concerns the effects of FIG on the training conducted by firms. This is motivated by the findings in Leuven \& Oosterbeek (2004), Abramovsky et al. (2011) and Schwerdt et al. (2012) of (very) high levels of deadweight in other training programmes, in which training subsidies essentially do not alter the level of training conducted by supported firms (or individuals). Here we investigate this question from different perspectives, exploiting the complementary training variables available in our data set.

33. First, we consider the accounting and financial information on non-salary staff expenditure, which is available for each firm between 2004 and 2017. We take this variable as a proxy for training, as the latter is one of its components, even if it may represent a small share of its total value, as we discussed when analysing our descriptive statistics (Table 1). Figure 1 presents the results regarding the $\beta_{j}$ coefficients from equation 1 (see also column 4 of Table A.4). We find that all coefficients before the year when the application are submitted (year 0 ) are statistically insignificant from zero, which supports the common trends assumption. Moreover, the results also indicate that as soon as the funding is made available (year 1), there is a marked spike in non-salary staff expenditure, of nearly ten percent and statistically significant from zero. This result is largely unchanged for year two after which the point estimates tend to drop while the confidence intervals tend to increase making the resulting estimates statistically insignificant at the end 
of the period. This result suggests that training has indeed increased in firms that received the FIG grants, when compared to their counterparts that were not successful in their bids. ${ }^{14}$

\section{Figure 1. DID effects: Log non-salary staff expenditure}

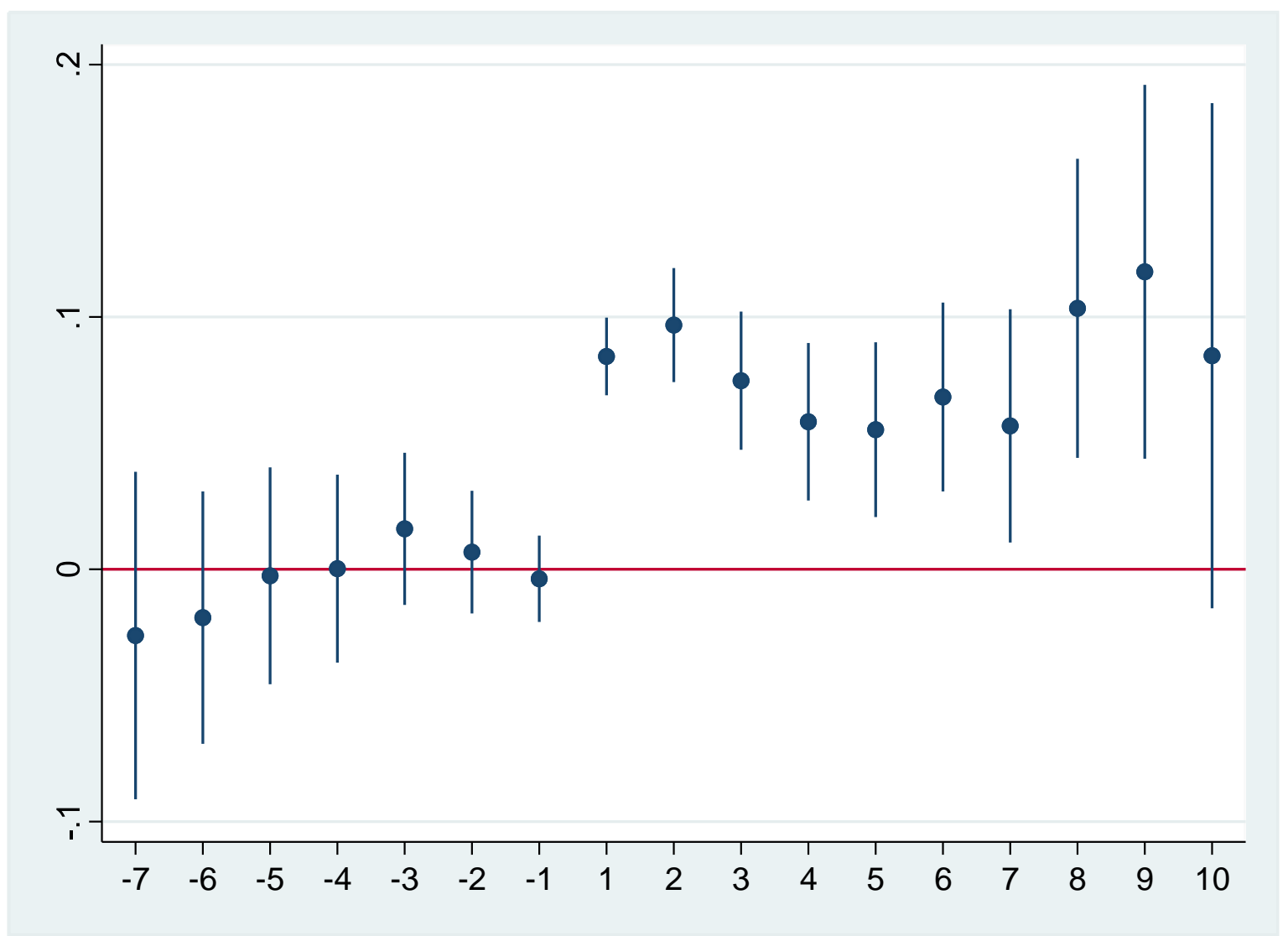

Note: The dependent variable is the log of each firm's annual expenditure on staff except salaries. Difference-in-differences model, including firm and year fixed effects. The full results including number of observations can be found in Table A.4 and Table A.5. The control group is composed of firms that submitted an application but were rejected (or dropped out). Each dot (line) indicates the point estimate ( $95 \%$ confidence interval) for the Treated * (YearX) coefficient concerning a particular relative year $\mathrm{X}$ (with respect to the benchmark year 0 when firms apply to the funding call): 1 denotes the first year when the funding is made available, 2 the year after that and so on while -1 denotes the year before the application for funding is submitted, -2 denotes the year before that and so on. In the case of QP or Cl variables, $\mathrm{X}$ ranges between -9 and 10 , covering the period 2002-2017; in the case of SCIE (accounting) variables, X ranges between -7 and 10, covering the period 2004-2017. Standard errors clustered at the firm level.

34. Second, we consider the more specific training expenditure variable, which is also available for all firms but only from 2010. Given this restriction, we focus on firms that apply to the last two FIG calls, of 2010 and 2011. In these two cases we can observe the training expenditure of each firm in at least one year before the funding was available (the year of 2010 in the case of the 2010 call) or as many as two years (2010 and 2011, in the case of the 2011 call). Figure 2 presents the results for each call, considering training expenditure both in logs and levels. We find in all cases large increases in training expenditure precisely in the first period when the FIG funding is provided, as in the analysis with the non-salary staff expenditure. However, when using training expenditure, in contrast to non-salary staff expenditure, the

14 It also suggests that firms that did not decrease their training, when comparing to other firms, once the funding came to an end, as the coefficients do not become negative after the first two years. In other words, firms do not appear to be frontloading their training expenditure as allowed under employment law. 
effects are shorter-lasting, coming to an end (becoming insignificant) in the third or fourth year following the submission of the application. Note that the funding typically is made available for training that starts in the first months of period one and lasts around 12 months in total, thus covering both years one and two. ${ }^{15}$

Figure 2. DID effects - Training expenditure, 2010 and 2011 calls, 2010-2017
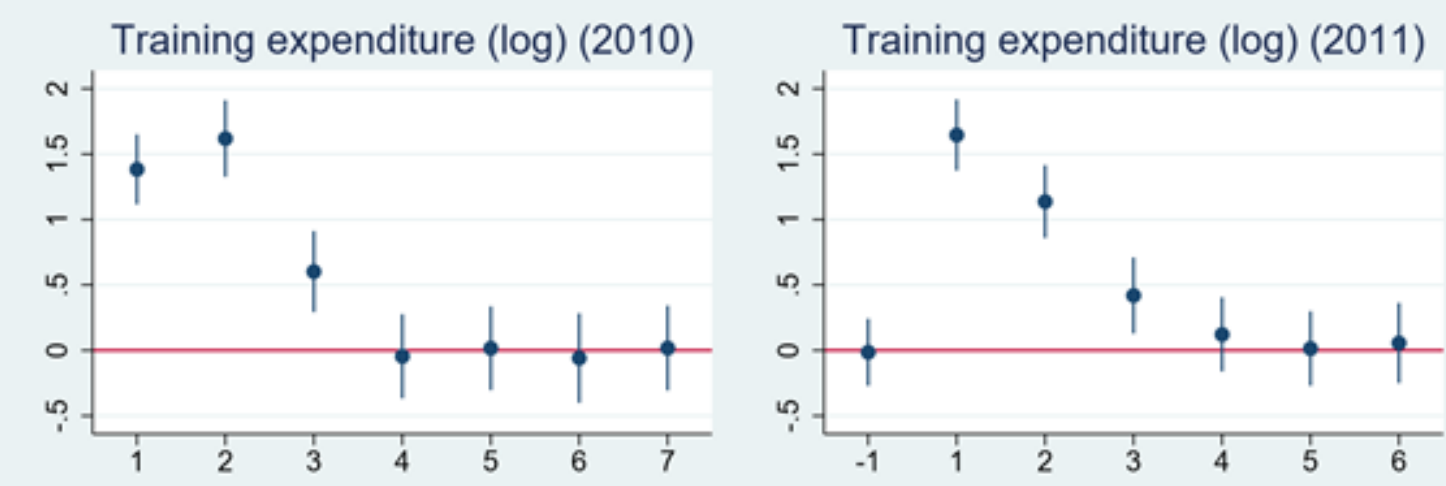

Training expenditure (2010)

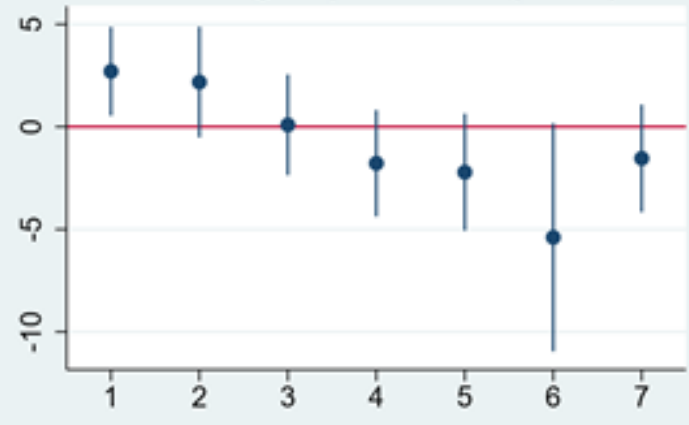

Training expenditure (2011)

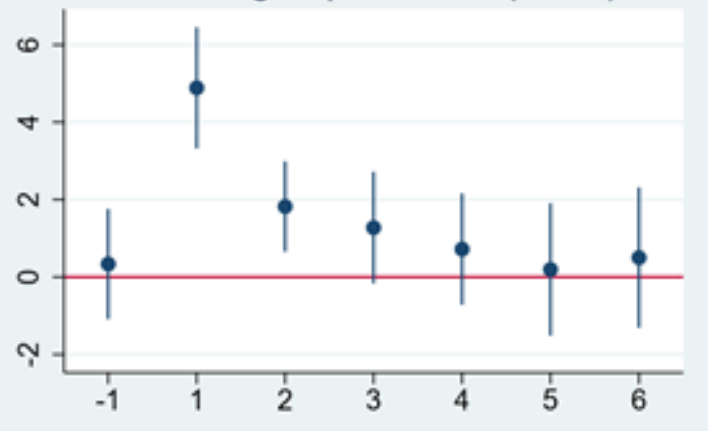

Note: The dependent variable is the log or level of each firm's annual expenditure on training. This variable is available only from 2010. Difference-in-differences model, including firm and year fixed effects. The control group is composed of firms that submitted an application but were rejected (or dropped out). Each dot (line) indicates the point estimate $(95 \%$ confidence interval) for the Treated* (YearX) coefficient concerning a particular relative year $X$ (with respect to the benchmark year 0 when firms apply to the funding call): 1 denotes the first year when the funding is made available, 2 the year after that and so on while -1 denotes the year before the application for funding is submitted, -2 denotes the year before that and so on. Standard errors clustered at the firm level.

35. Third, we analyse our detailed individual-level training data available for the years of 2010 and 2011 , which we aggregated to the firm level. In this case, we consider only the 2010 call, for which we can compare one year in the 'before' period (2010) and one year in the 'after' period (2011). Table 3 presents

15 While these results are consistent with a positive effect of FIG on training, it is not clear if firms register subsidised (reimbursed) training expenditure in the accounting variable we are exploiting here. If they do, the increase in training expenditure is of about 8,000 euros per firm (when summing the coefficients over the years in which they are significant), or less than one third of the 28,000 average grant provided - Table 2. If subsidised (reimbursed) training expenditure is not registered by firms in this variable, then the 8,000 could correspond only to the private co-payment required by FIG which would substantially underestimate the increase in training in these firms. Given the uncertainty above, regarding the interpretation of this variable, we conduct our deadweight analysis using the training hours variable discussed next. 
our first set of results, focusing on three complementary dependent variables (for each firm and year): training duration in total hours, in average hours, and in log total hours. We also break down total training duration in three non-mutually exclusive components (flexible, non-'catalogue' training; training provided by external organisations, namely training providers; and training conducted during the normal work schedule). We use a simplified version of equation 1, including simply an 'after' dummy (for the year 2011), an interaction of that dummy with a 'treated' dummy (for firms supported by FIG), and firm fixed effects.

Table 3. Training effects, 2010 and 2011, 2010 call, Different types (1/2)

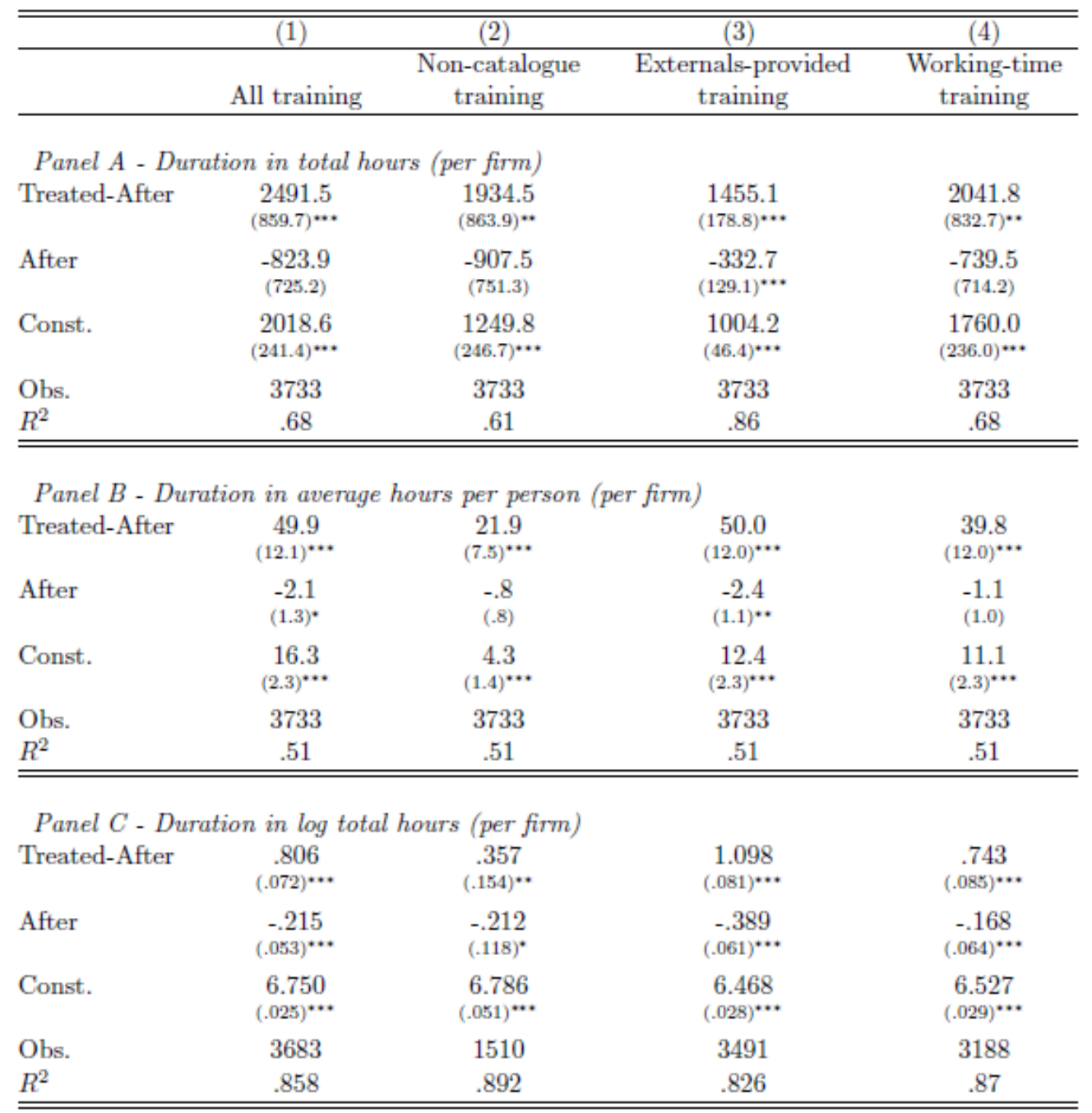

Note: Calculations based on training data from the QP data set referring to all months of the years of 2010 and 2011. All data aggregated from the worker level to the firm level. The variables in columns 2, 3 and 4 are not necessarily mutually exclusive. The sample is restricted to the years of 2010 and 2011 and to firms that applied to the 2010 FIG call. Difference-in-differences model, including firm fixed effects. The control group is composed of firms that submitted an application but were rejected (or dropped out).

36. The results indicate that, in all specifications and dependent variables, FIG participation leads to an economically and statistically significant increase in training. For instance, when considering the first column (total training duration) of Panel A (total hours, in levels) in Table 3, FIG support leads to an increase of 2,492 hours of training compared to firms that are not supported by FIG. This increase can be compared to the average training hours support provided by FIG for this specific call of 3,359 (as described in Table A.2, together with several other statistics for both approved and rejected firms in this call). This 
results in a ratio between training increase and training support of $74 \%$, indicating a deadweight of $26 \%$. However, we take the latter figure as an upper bound of the true deadweight as our effect is measured over one year only (as our QP training hours data is available only over one year in the 'after' period, 2011) while the FIG support could also take place over the following year (2012 in the case of the 2010 call). Indeed, only $46 \%$ of the total funding was made available in 2011. If this reflects the distribution of the training hours across the years, then the average training hours supported by FIG in 2011 is 1,545 (46\% of 3,359$)$ and the 2,492 hours of training effect actually corresponds to a crowd-in of $38 \%(1-1,545 / 2,492)$.

37. We also consider the impact of FIG in terms of the number of employees under training Table 4, Panel D - as an extensive margin of the programme. While we do not find significant results when considering the number of employees per se (column 1), the effects of FIG are significant in the share of the workforce, the log of the number of employees and the log of the share of the workforce (columns 2, 3 and 4). We also consider the two expenditure variables used before (from the SCIE data set) in the specific context of the 2010 call and for the years of 2010 and 2011 alone (Panels E and F, Table 4). This exercise seeks to assess the extent to which these variables (and, in particular, non-salary staff expenditure, which is available for nearly the full period we cover, 2004-2017) can be satisfactory proxies for training hours. We find that they both lead to statistically significant positive coefficients, even if of a much smaller magnitude in the case of non-salary staff expenditure. These results indicate that, even in the case of nonsalary staff expenditure, and despite the small percentage of such expenditure that is devoted to training, those variables are likely to be informative regarding changes in training provision. 
Table 4. Training effects, 2010 and 2011, 2010 call, Workers and Expenditure (2/2)

\begin{tabular}{|c|c|c|c|c|}
\hline & $(1)$ & $(2)$ & (3) & (4) \\
\hline & Level & Per worker & $\log$ & Log per worker \\
\hline \multicolumn{5}{|c|}{ Panel D - Employees under training } \\
\hline Treated-After & $\begin{array}{l}-7.027 \\
(14.401)\end{array}$ & $\begin{array}{l}.200 \\
(.117)^{*}\end{array}$ & $\begin{array}{c}.265 \\
(.061)^{* * *}\end{array}$ & $\begin{array}{c}.248 \\
(.062)^{* * *}\end{array}$ \\
\hline After & $\begin{array}{l}17.553 \\
(14.248)\end{array}$ & $\begin{array}{c}.094 \\
(.026)^{* * *}\end{array}$ & $\begin{array}{c}.404 \\
(.038)^{* * *}\end{array}$ & $\begin{array}{c}.414 \\
(.038)^{* * *}\end{array}$ \\
\hline Const. & $\begin{array}{c}70.380 \\
(4.643)^{* * *}\end{array}$ & $\begin{array}{c}.722 \\
(.022)^{* * *}\end{array}$ & $\begin{array}{c}2.681 \\
(.015)^{* * *}\end{array}$ & $\begin{array}{l}-.689 \\
(.015)^{* * *}\end{array}$ \\
\hline Obs. & 4356 & 4356 & 3733 & 3733 \\
\hline$R^{2}$ & .948 & .52 & .839 & .64 \\
\hline \multicolumn{5}{|c|}{ Panel E - Non-salary staff expenditure } \\
\hline Treated-After & $\begin{array}{l}.040 \\
(.021)^{*}\end{array}$ & $\begin{array}{l}.0006 \\
(.0006)\end{array}$ & $\begin{array}{c}.093 \\
(.014)^{* * *}\end{array}$ & $\begin{array}{c}.068 \\
(.017)^{* * *}\end{array}$ \\
\hline After & $\begin{array}{l}-.028 \\
(.020)\end{array}$ & $\begin{array}{l}.0003 \\
(.0003)\end{array}$ & $\begin{array}{l}-.006 \\
(.010)\end{array}$ & $\begin{array}{l}.014 \\
(.011)\end{array}$ \\
\hline Const. & $\begin{array}{c}.440 \\
(.006)^{* * *}\end{array}$ & $\begin{array}{c}.004 \\
(.0001)^{* * *}\end{array}$ & $\begin{array}{c}-2.389 \\
(.004)^{* * *}\end{array}$ & $\begin{array}{l}-5.657 \\
(.004)^{* * *}\end{array}$ \\
\hline Obs. & 4000 & 4000 & 3976 & 3976 \\
\hline$R^{2}$ & .995 & .57 & .988 & .891 \\
\hline \multicolumn{5}{|c|}{ Panel F - Training expenditure } \\
\hline Treated-After & $\begin{array}{c}2.769 \\
(1.118)^{* *}\end{array}$ & $\begin{array}{c}.128 \\
(.029)^{* * *}\end{array}$ & $\begin{array}{c}1.288 \\
(.143)^{* * *}\end{array}$ & $\begin{array}{l}1.234 \\
(.144)^{* * *}\end{array}$ \\
\hline After & $\begin{array}{l}-.226 \\
(.341)\end{array}$ & $\begin{array}{l}-.009 \\
(.007)\end{array}$ & $\begin{array}{l}-.043 \\
(.092)\end{array}$ & $\begin{array}{l}-.004 \\
(.093)\end{array}$ \\
\hline Const. & $\begin{array}{c}4.832 \\
(.228)^{* * *}\end{array}$ & $\begin{array}{c}.068 \\
(.006)^{*+*}\end{array}$ & $\begin{array}{c}.944 \\
(.035)^{* * *}\end{array}$ & $\begin{array}{l}-3.039 \\
(.036)^{* * *}\end{array}$ \\
\hline Obs. & 4000 & 4000 & 1000 & 1000 \\
\hline$R^{2}$ & .875 & .695 & .834 & .792 \\
\hline
\end{tabular}

Note: See notes to Table 3. Panel D uses QP data as in Panels A to C of Table 4. Panels E and F uses SCIE data. Difference-in-differences model, including firm fixed effects. The control group is composed of firms that submitted an application but were rejected (or dropped out).

38. We conclude that FIG had a significant positive effect on the training conducted by firms and limited deadweight, of not more than $24 \%$, and possibly much less, involving some crowd-in. This result contrasts with earlier studies about other training programmes, namely Abramovsky et al. (2011) and Schwerdt et al. (2012). The result is particularly noteworthy given the labour law requirement of a minimum amount of training provision by firms and the fact that FIG did not require supported firms to exceed it. Some of the explanations for the limited deadweight found here may include the targeted nature of the programme. Indeed, FIG focused on firms that could benefit from the training support but that would not necessarily conduct the training investment without the grant, given the uncertainty involved in training because of poaching of workers or the sheer difficulty in estimating its returns (even in a context without poaching). The timing of the programme, coinciding with the financial crisis of 2008/9 and the euro sovereign debt crisis of 2011/13, may also have played a role in the limited deadweight found here, as opportunities for borrowing funds from the financial markets to invest in training became more limited, especially in 2011/13. 


\subsection{Firm performance outcomes}

39. Having established a positive effect of FIG on training, we now consider the wider firm performance implications of the increased levels of training conducted in treated firms. Improvements in the human capital of the workforce following from training may potentially be observed in multiple dimensions of firms. Fortunately, the richness of the data sets that we put together allow us to conduct an extensive examination of several margins. In this section, we present our results regarding the main dimensions of firm performance, while in the next section we consider a number of additional or related variables.

40. We start with the case of (annual log) sales, again using the difference-in-differences model of equation 1. The results are depicted in Figure 3 and presented in detail in Table A.4 and Table A.5, as for other key variables. We find that FIG firms follow the same pattern as firms not supported by the programme up to year -1 (2007 to 2011, depending on the specific call applicable in the case of each firm), with very similar point estimates, always close to zero, and wide confidence intervals. This result supports the common trends prior to treatment assumption underpinning difference-in-differences. However, the pattern is changed from year one (the first year in which selected firms received FIG grants), first with a borderline statistically significant positive coefficient, and then with significant coefficients for all following years, between about $5 \%$ and $15 \%$. The coefficients of the latter years are subject to wider confidence intervals, possibly reflecting the smaller underlying sample sizes (as only the earlier calls can be followed that far), but are still statistically significant.

\section{Figure 3. DID effects: Log sales}

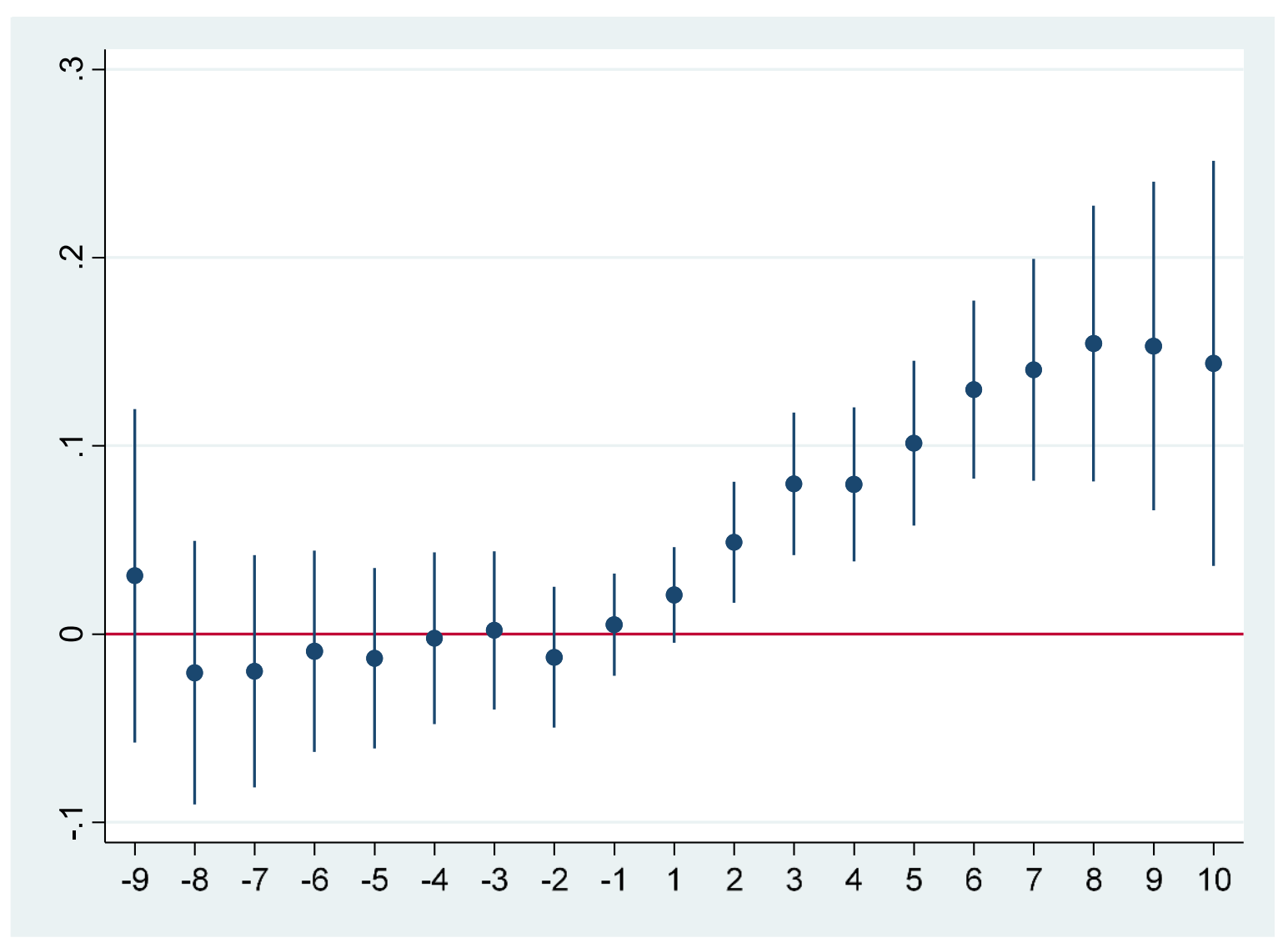

Note: The dependent variable is the log of each firm's annual sales. Source: QP data set. See notes to Figure 1. 
41. Our second variable is gross value added, defined as (log) output (at basic prices) minus intermediate consumption (at purchaser prices). The results - Figure 4 - are very similar to those of sales. We find very little differences between treated and control firms up to treatment and a significant gap emerging and growing precisely from the year when the FIG training grants are made available and training is increased, first at $3 \%$ and increasing up to $12 \%$ around year seven.

\section{Figure 4. DID effects: Log gross value added}

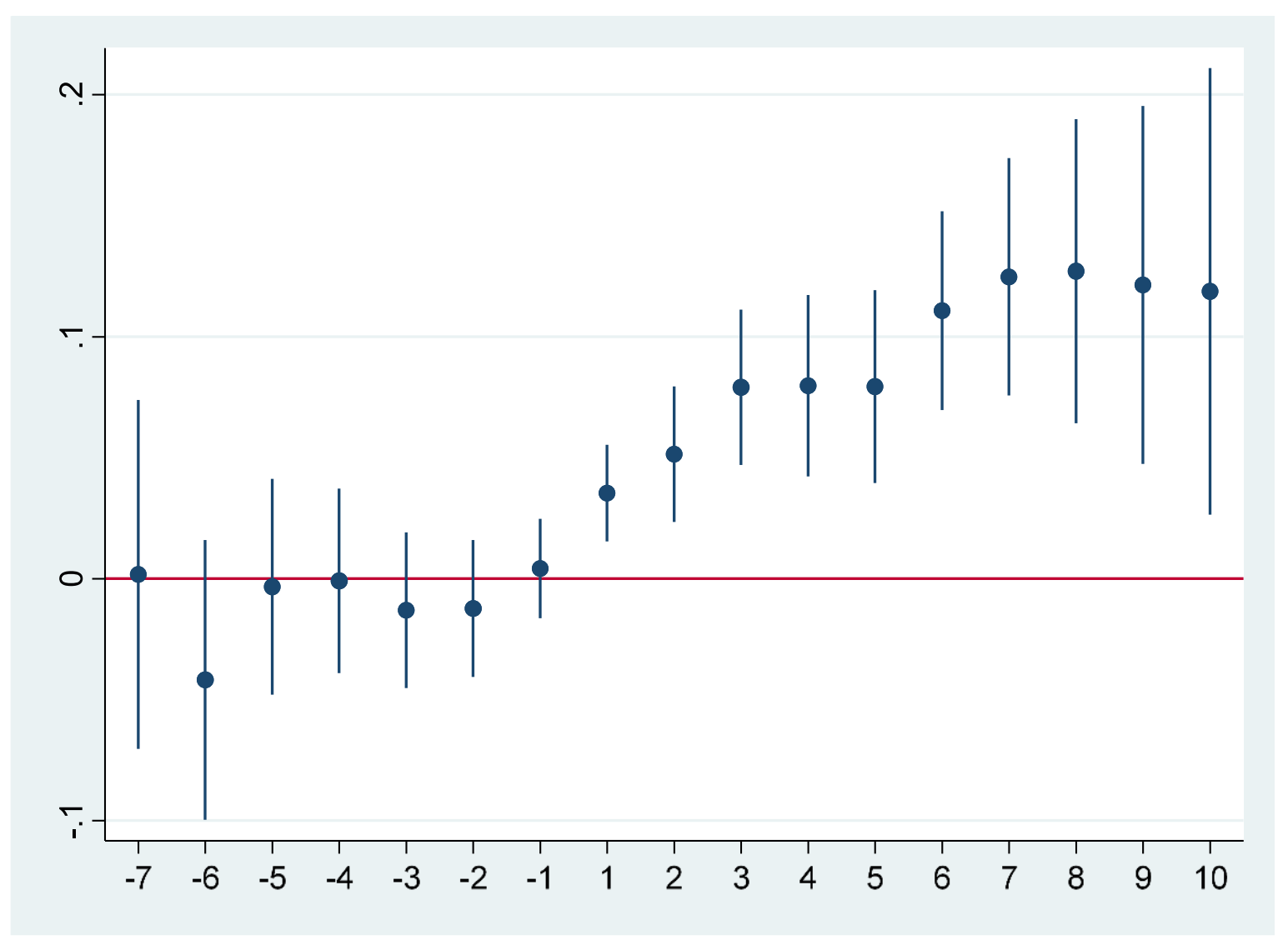

Note: The dependent variable is the log of each firm's gross value added. Source: SCIE data set. See notes to Figure 1.

42. An important component of the total sales of FIG firms (both accepted and rejected applicants) was exports. Moreover, the FIG programme also sought to support firms in their progression along the quality ladder towards increased exports value (Bloom et al. forthcoming). Figure 5 and Figure 6 present our results regarding the impact of the additional training supported by FIG on exports, considering its extensive and intensive margins, respectively. We find that FIG had a positive in both cases, even if typically shorter-lived (for only one or two years), while occurring soon after the training was conducted. While the point estimates are large at least in the case of the intensive margin, they are also subject to larger confidence intervals (2\% effect by year three in the case of the extensive status; and a $15 \%$ effect already by year one in the case of exports volume, but subject to a large confidence interval). In contrast to the previous variables, we find evidence of a positive trend in the 'before' period, namely between years -9 and -5 , but only in the case of export status. 
Figure 5. DID effects: Export status

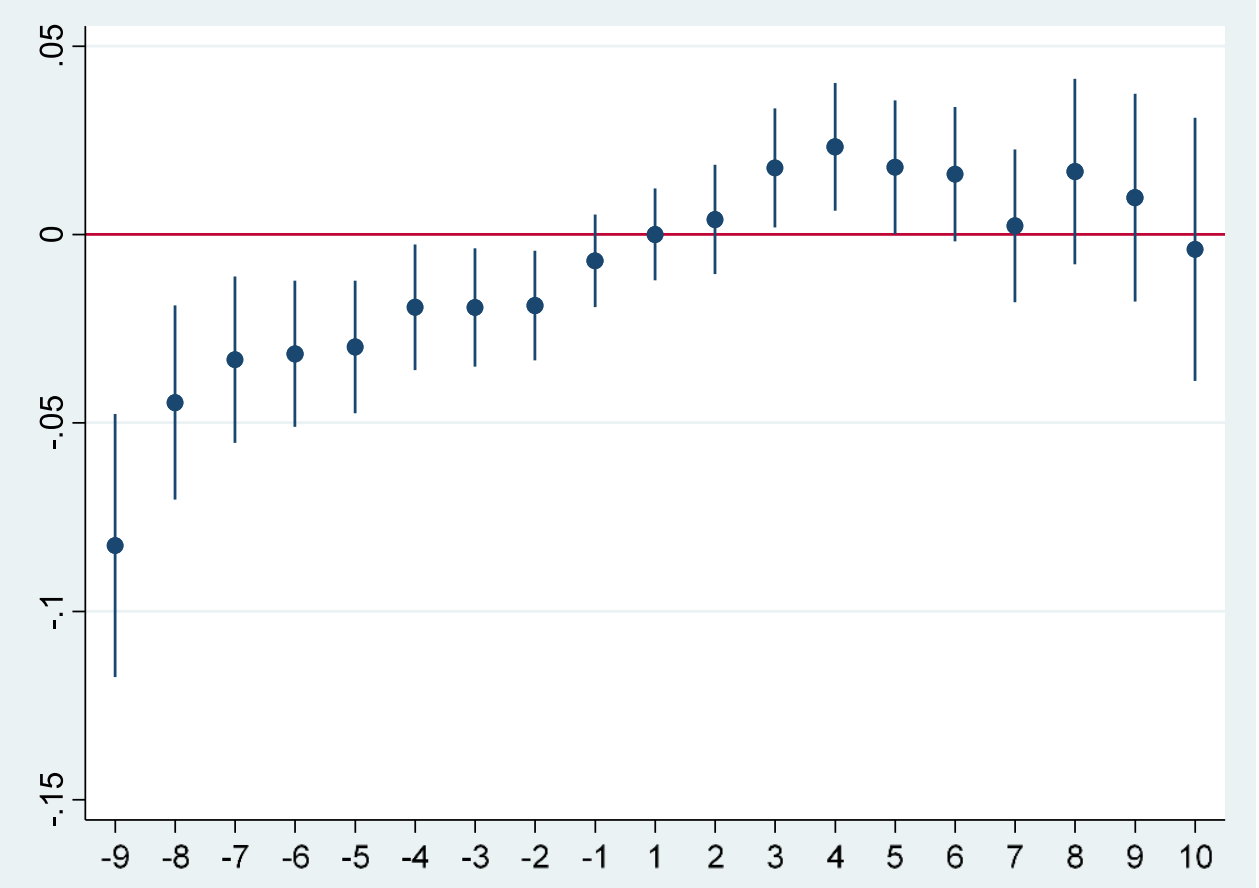

Note: The dependent variable is a dummy variable equal to one if the firm exports at least one euro in the year. Source: $\mathrm{Cl}$ data set. See notes to Figure 1.

Figure 6. DID effects: Log exports volume

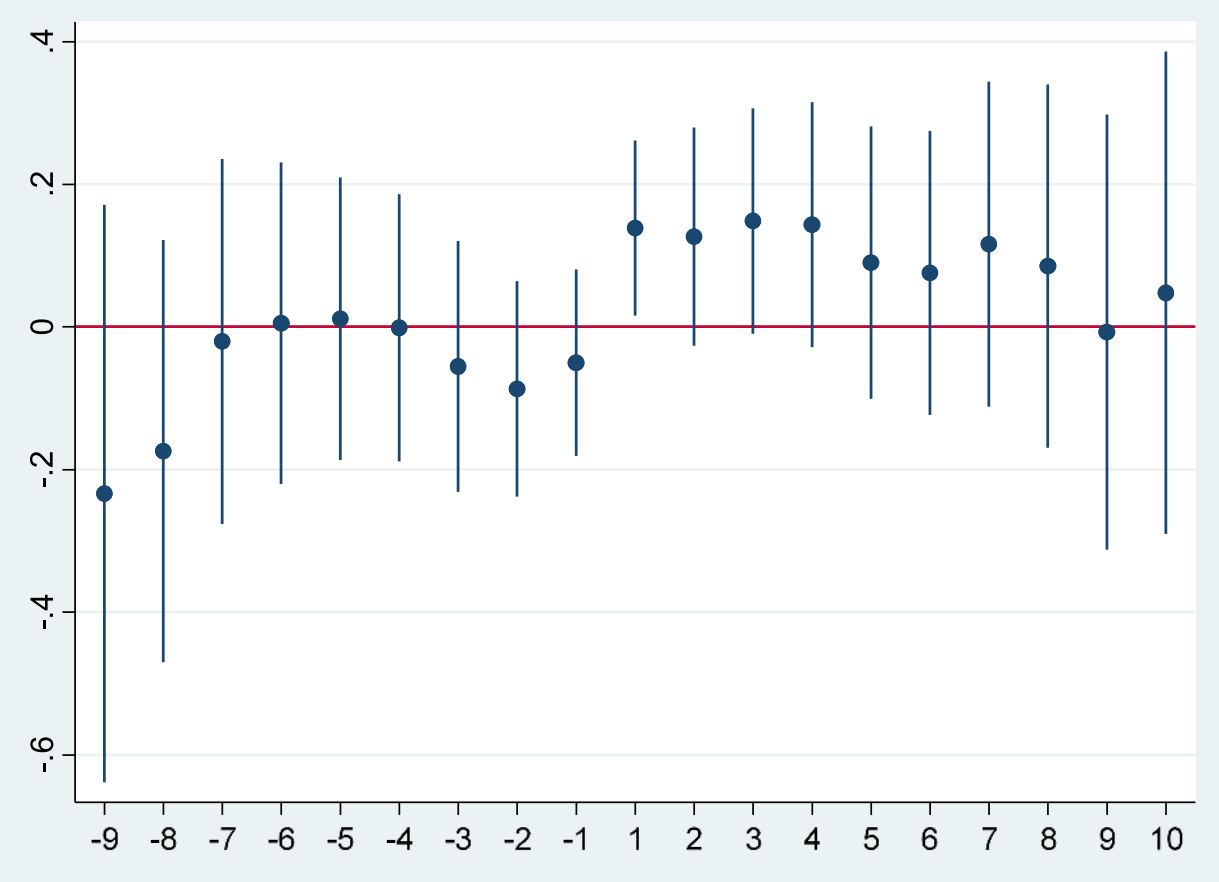

Note: The dependent variable is the log of the firm's exports. The sample is restricted to firm-years in which exports are greater than zero. Source: $\mathrm{Cl}$ data set. See notes to Figure 1. 
43. Another variable of interest, on its own and as a component of productivity, is (log) employment (the headcount of employees as of October of each year). As far as we know, this is the first study that considers the potential effects of training upon employment. However, employment is a potentially relevant variable in this context, as the increased firm productivity that may follow from training may spur firms to both retain their current workers and hire additional staff. Figure 7 presents our results, which indicate again no significant differences over time between FIG supported and rejected firms up to year -1 . However, this pattern is reversed from year 1 , when a significant gap of $4 \%$ emerges. This significant gap continues at least year 4 , when the point estimates remain similar but less precise and generally not significantly different from zero. ${ }^{16}$ One may use this estimate to compute a crude measure of the cost per job created by FIG. If one were to divide the 30,000 euros of the average subsidy above by the extra jobs in the average firm that received a grant $(111.6$ employees) multiplied by the employment effect $(4.7 \%$ in the third year), this would lead to an average cost per job of 5,750 euros. This is closer to the lower bound of the interval of effects presented in Criscuolo et al. (2019) (page 80, $\$ 3,541-\$ 26,572$ ).

\section{Figure 7. DID effects: Log number of employees}

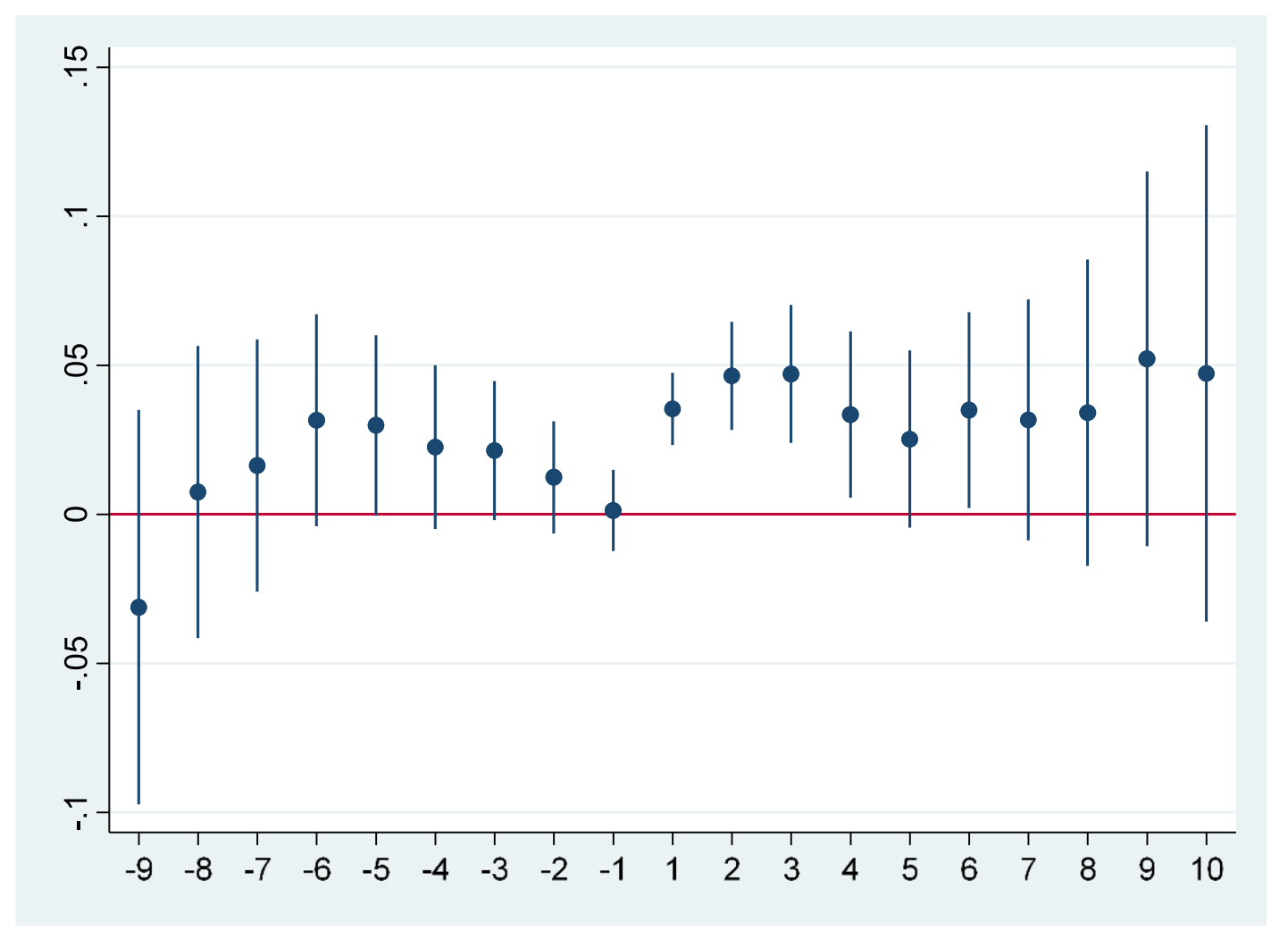

Note: The dependent variable is the log of each firm's total employment as of October of each year. Source: QP data set. See notes to Figure 1.

\footnotetext{
16 Firms may also need to hire workers temporarily to replace their permanent staff while they are undergoing training. This may be particularly important when training is conducted during normal working time, as is the case here (Table 3 , columns 1 and 4). Note that the QP data that we use to measure employment in firms includes workers under fixedterm contracts but not workers under temporary work arrangements. The latter are registered in QP with the temporary work agencies that officially employ them, but we have no information on the firms in which these workers are placed. Replacement of employees under training is more likely to involve temporary worker than fixed-term contracts. Our results are therefore not likely to be driven by worker replacement.
} 
44. Having studied the effects of FIG on employment, we now consider the case of (labour) productivity, measured here by the ratio of sales and the number of employees (as above). As both variables exhibited positive effects, it is unclear if FIG may also have improved firms' productivity. Figure 8 indicates that it did, with statistically significant effects from year 4 onwards, with an effect of about $5 \%$ and increasing further over the remaining years. Again, differences between the two types of firms were not significant up to year -1 .

\section{Figure 8. DID effects: Log sales per worker}

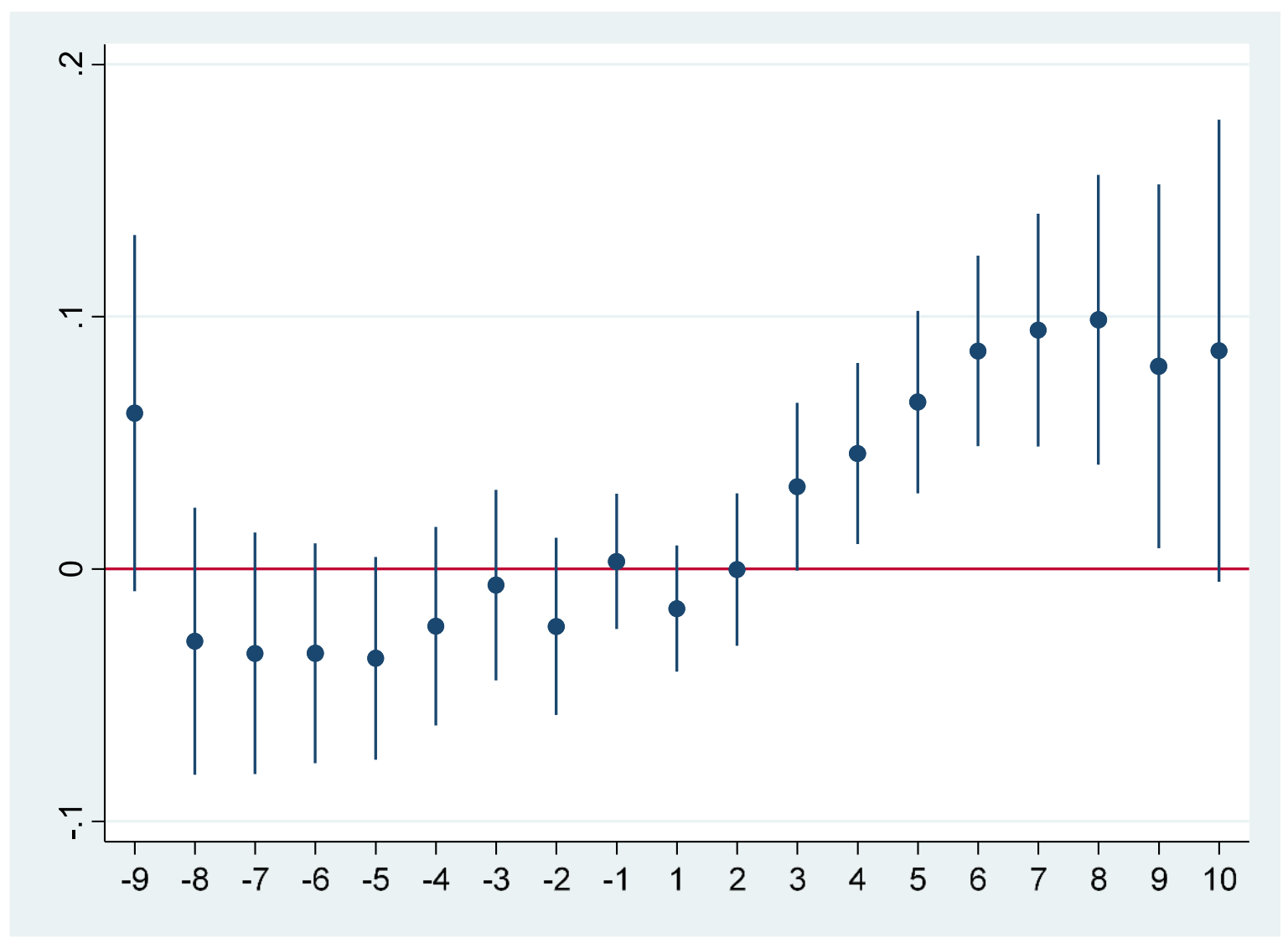

Note: The dependent variable is the log of the ratio of total sales (QP) by total employment (QP). See notes to Figure 1.

45. Investment in human capital through training may also foster investment in physical capital. Figure 9 considers the investment variable available in our accounting data (SCIE), gross fixed capital formation, which we measure as a share of total sales. The results present suggestive evidence that it may also be positively affected by FIG grants, namely with a large point estimate in the second year. However, all point estimates are insignificant at standard confidence levels. This may be explained by the relatively small size of the training grant, which may not be enough to spur additional investments in physical capital, for instance. 
Figure 9. DID effects: Investment, profits and taxes
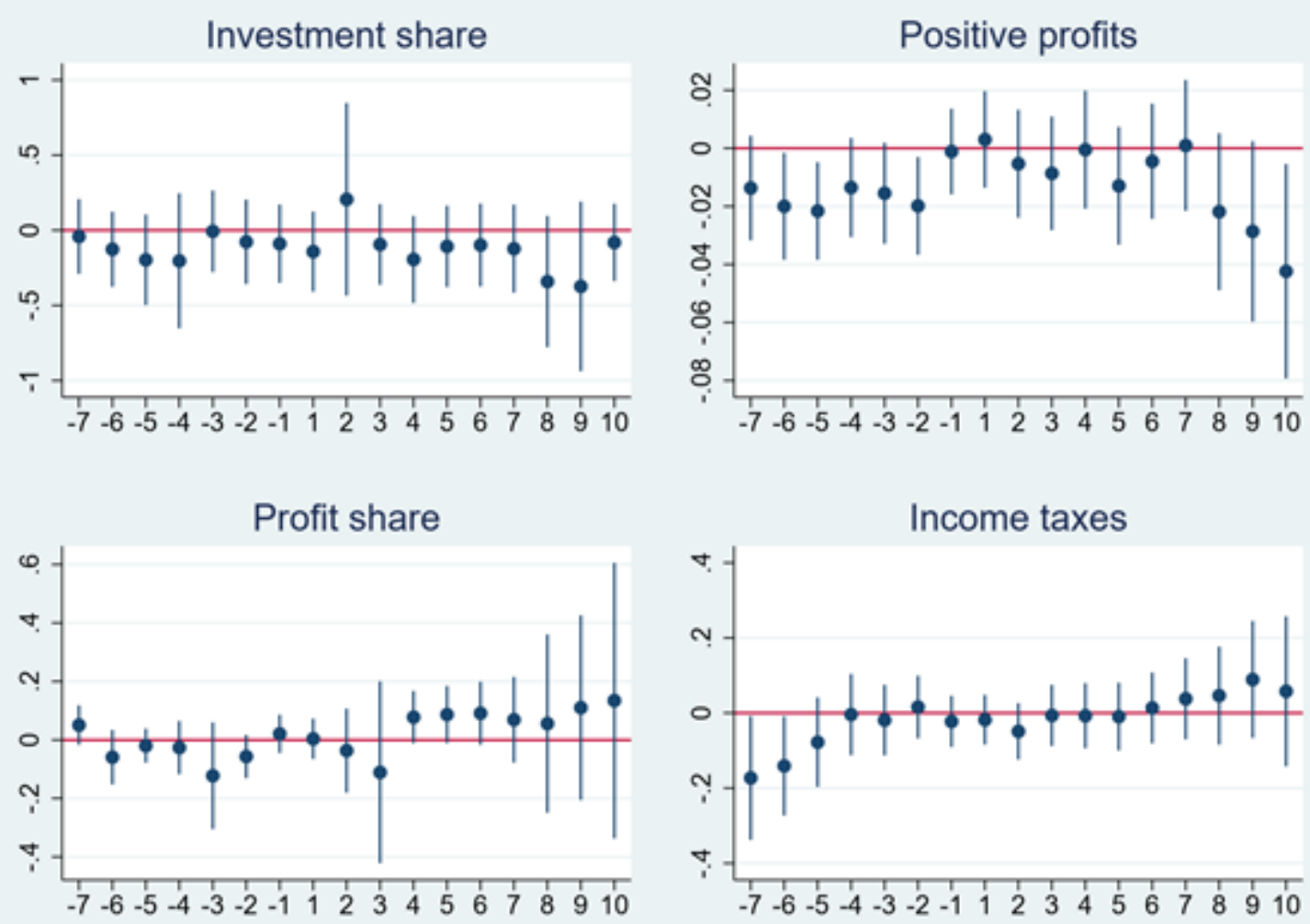

Note: The dependent variables are (clockwise, from top left corner): the ratio between investment (SCIE) and sales (QP), a dummy variable equal to one if accounting profits (SCIE) are positive, the ratio between profits and sales (QP) and income taxes paid by the firm (SCIE). The number of observations are 103,708, 133,221, 103,708, and 93,812, respectively. See notes to Figure 1.

46. We also consider the case of profitability, using its accounting version available in the SCIE data and considering both whether the firm has positive profits and the ratio between profits and sales (Figure 9). This variable exhibits a noisy pattern over the period, including large confidence intervals. There is some suggestive evidence of positive effects from year four onwards in the case of the profit share but the coefficients are again not statistically significant at the $95 \%$ level. We also find that no significant differences in revenue taxes paid between the two types of firms over the period examined.

47. The results are also very similar when restricting our full sample to narrow bands of the scoring range around the funding threshold, an approach that may ensure greater comparability between treated and control firms. For instance, in Figure 10 we derive our results exclusively from a two-bin band on either side of the threshold (i.e. 0 and 2.5 vs -2.5 and -5 in the centred score, which takes only values that are multiples of 2.5 , according to the scoring grid of the FIG agency). ${ }^{17}$

17 See Figure A.1 for the full distribution of the scores. We also find similar results when we consider instead a fourbin band (i.e., 0 up to 7.5 vs -2.5 up to -10 ) - Figure A.18. This is also the case when we instead exclude firms at the threshold, namely firms with scores of -2.5 or zero - Figure A.19. 
Figure 10. DID effects - Firms within 2.5 points of funding threshold

\section{Sales}

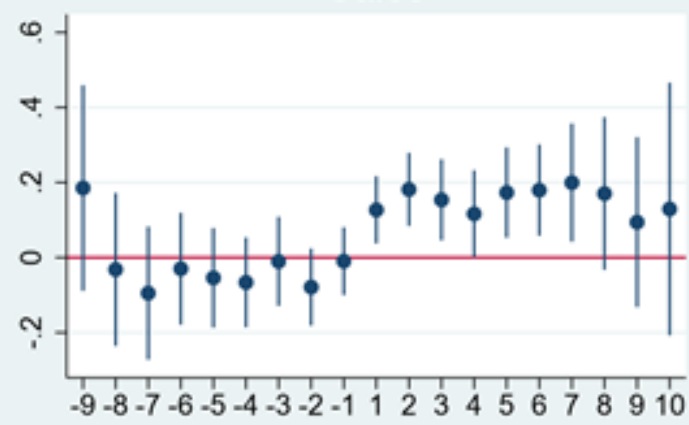

Gross added value

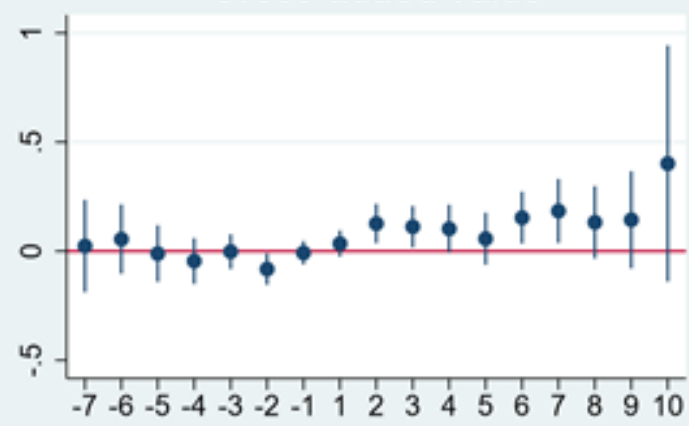

Number of employees

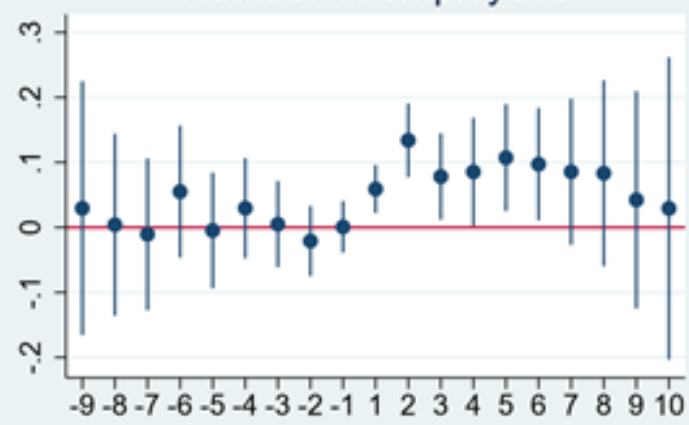

Non-salary staff expenditure

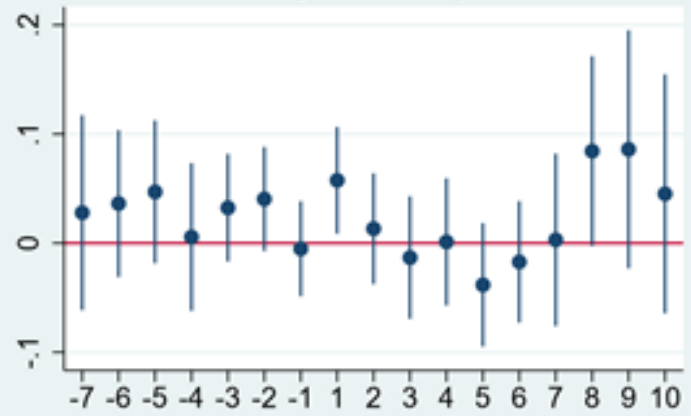

Note: The figures are based on a subset of firms with application scores within 2.5 points of funding threshold. The number of observations used in the estimations is 16,269 . The dependent variables are (clockwise, from top left corner): Net job creation rate (the ratio between the employment change between year $t$ and year $t-1$ and the average employment of both years), the hiring rate (the ratio between the number of workers hired in year $t$ by the average employment of years $t$ and $t-1$ ) and the separation rate (the ratio between the number of workers that left the firm in year t the average employment of years $t$ and $t-1$ ). All variables computed using the $Q P$ data. Each figure corresponds to a separate estimation of a difference-in-differences model.

48. In conclusion, we find that the training grants made available by FIG led both to higher levels of training and higher levels of firm performance, as measured by multiple complementary variables. Besides sales and value added, the additional training also improved exports (along both the intensive and extensive margins), and productivity. On the other hand, the effects on profitability were generally not significant, which may be related to the noise of the variable used. The effects along the last two dimensions took longer to emerge while the international trade and, to a lesser extent, employment effects proved to be short-lived. The employer effects last least four years, after which they become less precise from a statistical standpoint. However, the main effects on output and value added appear to be cumulative and largely permanent, at least over the long, ten-year period that we analyse with our data. ${ }^{18}$

18 The positive effects on value added, productivity and exports may also indicate that the increase in sales effect documented above is driven mostly from market expansion and not market stealing. The latter case would involve reduced sales across FIG-rejected firms or third-party firms operating in the same industries as FIG-supported firms. 


\section{Additional results}

49. We conduct three types of robustness checks, which we present in the following subsections. First, we examine other potential outcomes, again exploiting the richness of our data set. Second, we examine the robustness of our findings. Specifically, we split our main sample in different ways, including across the five calls that are pooled in our main analysis above. We also compare our results across different subsets of firms.

\subsection{Other outcomes}

50. The first additional variable that we examine here is non-salary staff expenditure on a per worker basis. Figure A.3 presents the results, which are very similar to those based on total expenditure, with large spikes in the first two years, but now immediately followed by insignificant effects. A second variable we consider is again sales but, in its version, reported in the SCIE data set (while above we use the version reported in the QP data). Figure A.4indicates very similar effects as before. We also consider the case of gross value added per worker, an alternative measure of productivity. We again find a similar pattern as before - Figure A.5 even if subject to less precision than when considering sales per worker.

51. An important result of our main analysis was the positive effects of increased training on employment. Here we investigate this finding further by considering its net job creation rate counterpart (defined as the difference in employment in one year compared to the previous, divided by the mean of the two employment levels). We also decompose it between the hiring and separation rate, by drawing on the individual level information in each firm. (We define the hiring rate as the percentage of workers hired between January and October of each year in terms of the mean of total employment over the two years; and the separation rate as the difference between the hiring rate and the net job creation rate.)

52. Figure A.6 presents the results for these three variables. These indicate that net job creation rates increase by around three percentage points $(p p)$ in year 1 , while the hiring rate increases by about one $p p$ and the separation rate drops by two pp. We find evidence on common trends between FIG-supported and FIG-rejected firms up to year -1 in the cases of net job creation and hires and up to year zero in the case of separations. In the first two cases, the coefficients for most of the 'before' period are significantly different than zero but are statistically equal over the eight years covered. We believe this reflects some degree of anticipation driven by the announcement of the results of each call at the end of year zero, leading to an increase in the hiring rate (and thus an increase in the net job creation rate) already at that time. (Most funded training starts in January of year one and the results in most calls were announced in September of year zero.)

53. Significant changes arise in year 1 and until year 3 in the cases of the net job creation rate and the separation rate, and in year 1 alone in the case of the hiring rate. These results indicate that the increase in employment in FIG-supported firms is driven by a combination of increased hires and reduced separations, but with a stronger contribution from the latter, both in terms of the magnitude of the effect (more than twice larger) and its duration in time (three years compared to only one). Following the additional training provided, firms appear to become keener and or able to retain their staff, which contributes to a significant boost to the firms' employment. The increased hires may arise from a rightward shift in labour demand following from a firm-wide (and not only worker-specific) increase in productivity. Note that FIG also sought to support the training of (senior) managers. In any case, such increased hires result may suggest a potential role for training grants as hiring subsidies.

54. To investigate further our employment findings, we also examine several dimensions of the workforce of FIG supported and rejected firms. Figure A.7 presents our findings regarding the female share, age, schooling and tenure. First, we find that in all four cases, there are no significant differences between FIG-supported and FIG-rejected firms up to year when the applications are submitted. While this remains true in the 'after' period in the case of gender, the three remaining variables exhibit changes in 
their profiles as soon as the FIG-supported training is conducted. Average age and average tenure drops - reflecting the increase in hires -, while schooling increases - reflecting the typically higher schooling levels of younger workers, that are likely to be overrepresented amongst new hires. Some of the latter effect may also stem from higher-level schooling diplomas awarded to individuals previously hired by these firms, in particular those supported by FIG.

55. Figure A.8 considers the wage dimension (both in terms of base and total wages, the latter including overtime, bonuses and other wage components), as well as the nature of the employment contracts (open-ended, as opposed to fixed-term) and the number of hours of work. We find in all cases insignificant effects, both over the 'before' period but also during the years following FIG-supported training, even if point estimates tend to change in the direction of higher wages and fewer hours. Note that these results do not necessarily imply that the individual returns to training are zero as we have identified above important employment effects which could affect the composition of the workforce of each firm. Such composition effects would bias firm averages towards younger, less experienced and lower paid employees. ${ }^{19}$

56. Firm survival is an additional relevant dimension of firm performance. We examine this dimension by creating a dummy variable equal to one for the years in which each firm is not present in the data, either because it had not yet entered the market or because it had already exited. We then re-estimate our main model of equation 1 using such dummy variable as our dependent variable. Figure A.9 presents the results, which indicate that there are no significant differences between the two group of firms over the three years before the FIG award (or not), but lower non-presence before that - i.e., FIG-awarded firms tend to be older than their non-awarded counterparts over this nine-year time window. More importantly, we find that, over the period following the FIG award, recipient firms exhibit a significantly lower probability of non-presence (or exit), up to $-12 \%$ after ten years.

57. Finally, we also analysed the potential role of multiple testing, drawing on Jones et al. (2019), and computing the Bonferroni-Holm, Sidak-Holm and Westfall-Young (Westfall \&

58. Young 1993) adjusted p-values. Specifically, we considered the first four DID coefficients (the interactions between the programme dummy and the first four after years), twelve key outcome variables, while using 30 bootstraps. The twelve outcome variables are: log sales, log number of employees, log sales per worker, export status dummy, log exports, log profits, profits per sales, log profits tax, log non salary staff expenditure, log investment, log sales (2nd variable), and log gross added value per worker. The results are presented in Table A.6 and Table A.7 and indicate that, as expected, the number of coefficients that remain significant drops, in the case of Bonferroni-Holm and Sidak-Holm to half (from 28 to 14), although to only two in the more extreme case of Westfall-Young. Importantly, the variables that remain significant under Bonferroni-Holm and Sidak-Holm are key variables, namely training, employment and sales.

\subsection{Different subsamples}

59. Our first analysis in this subsection concerns the potential heterogeneity across the different FIG calls that we pooled together in our main analysis above. Here we consider each one of the five calls separately. Part of our motivation stems from the possible interaction between training and the business cycle and the different GDP growth rates in Portugal over the period examined (including $-3.1 \%$ in 2009 and $-1.7 \%$ in 2011 and positive rates in the years of the remaining calls). Our analysis is focused on four

19 Note also that sectoral collective bargaining is pervasive in Portugal as in several other European countries and may result in compressed wage differentials that limit the scope for wages increases, even in the context of increased productivity and profitability (Martins 2019). Another factor could be that, without the grant, firms were paying workers in lieu of the training (as required by law). As training is provided (with the grant), wages would counterfactually decrease. 
main outcome variables: sales, employment, added value, and non-salary staff expenditure. The results are again based on equation 1, except that calendar year dummy variables are excluded: unlike when we pool the different calls in the results of Section 5, now each 'relative year' $j$ also corresponds to a specific calendar year $t$. This also implies that the time windows considered for each call vary - as we move towards more recent calls, we examine longer 'before' periods and shorter 'after' periods.

60. The results are presented in Figure A.10, Figure A.11, Figure A.12, Figure A.13, Figure A.14. As sample sizes drop, the precision of some of our estimates also declines. This is clear in the first call, which is also the one with fewer applicants and successful firms. However, even in this case (Figure A.10), we find positive sales and added value effects, even if only materialising later, from years 6 or 7 (2013 or later). While employment effects are not significant in this case, non-salary staff expenditure is, although only in years 2 and 3 (2009 and 2010). ${ }^{20}$

61. The results for the 2008 call are more precise, indicating significant added value effects from year two (2010) and significant employment and non-salary staff expenditure from year one (2009). In contrast, in the case of the 2009 call, we do not find significant effects in any variable, except in the case of nonsalary staff expenditure. Finally, in the cases of the 2010 and 2011 calls (Figure A.13 and Figure A.14), we find again significant effects in all variables from year one (and insignificant differences in all years in the 'before' period).

62. In conclusion, we find a remarkable degree of similarity in the results across the five calls, with the exception of 2009 - although even in this case non-salary staff expenditure also increases as in the other calls. The 2009 call funded training that was conducted in a year of economic growth (2010), while all other calls, except 2007, funded training conducted in years of economic contraction. While only suggestive, this relationship may indicate that training delivers higher returns for firms when conducted in times of economic downturn. This could be driven by lower opportunity costs from lost production and sales while workers are participating in training session. This result would mirror similar findings in the case of the training of jobseekers (Lechner \& Wunsch 2009). Other explanations for our results involve the diminished opportunities for trained workers in terms of employment in other firms during recessions, particularly at higher wages, and the additional financial market restrictions that applied during both downturns (making it very unlikely that these firms would have invested in training in the absence of the grants). The latter point highlights some potential overlap between training grants and short-time work schemes (Cahuc et al. 2018). In any case, these results highlight a novel type of 'lock-in effect', here in the context of employed individuals. This contrasts with the training lock-in observed for unemployed jobseekers, as spending time in training can have a negative effect on the time spent searching for jobs and on transitions to employment, at least over the short run.

63. As discussed before, there is a modest degree of firm exit in our sample. We investigate the role of this in our findings by comparing results for firms that are present in all years (2002-2017) - Figure A.15 - and firms that enter the market after 2002 or leave it before 2017 - Figure A.16. We find in both cases the same patterns that we observed in our main results, namely positive effects from FIG on sales, employees, added value and non-salary staff expenditure from year one onwards (or soon after year one), without any statistically significant differences up to year zero.

64. An important additional robustness check follows from redefining our control group to include exclusively the (423) firms that received a positive score (at or above the funding threshold) but declined to accept the funding. Their decision may have been influenced by changes in their training projects or business priorities. These firms may be regarded as a more comparable control group than our original one in the sense that their applications were regarded to be of a higher quality than those of rejected

20 Note that the applications deadline for this call was set in early 2008, implying that funding was conducted from mid 2008, which will explain that the effects on non-salary staff expenditure, our proxy for training expenditure, and, to a lesser extent, sales and value added also emerge later. 
applicants. (Leuven \& Oosterbeek (2008) follow a similar approach in their study of the wage returns to training amongst a sample of Dutch workers.) Indeed, our description of the resulting samples in Table A.8 and Table A.9 indicate fewer observable differences between the two groups of firms. Our results Figure A.17 - are again very similar to the benchmark case, with positive effects in the four key variables starting again at the timing of FIG support and no statistical differences up to that point.

65. Our final robustness check in this subsection concerns the role of the firms that apply (unsuccessfully) more than once to FIG calls. In our benchmark sample criteria, we keep these firms in the control group of each call in which they apply. Here we conduct our analysis excluding these firms, i.e. restricting our control group to firms that apply (unsuccessfully) only once. Figure A.20 presents the results, which are again very similar to our benchmark findings.

\subsection{Heterogeneity analysis}

66. In our last subsection, we examine the effects of FIG-induced training upon different types of our firms. First, we consider the role of the sector, comparing the cases of manufacturing and services Figure A.21. While we find that our main results apply equally in the two sectors, they are stronger in manufacturing, both in terms of their size and of the speed at which they emerge. This result may indicate that training in manufacturing tends to be more effective, perhaps because of its possibly stronger load in cognitive elements when compared to training in services.

67. Next, we compare firms of different size, considering their size in the year when they submit their applications and dividing our sample at the median of 28 employees. Firm size may also be regarded as a proxy for financial constraints, as larger firms typically have more means to fund their activities, including training. Figure A.22 indicates that, consistent with the role of financial constraints, the effects of FIG funding were larger in raising non-salary staff expenditure in smaller firms. The effects on firm performance are also larger in smaller firms.

68. Another potential driver of our results is the different level of quality of the submissions by interested firms. We examine this by comparing the results in our key variables for firms that applied to calls that had a threshold higher than the minimum one (50) and the level immediately above (52.5). We find - see Figure A.23 - that both the non-salary staff expenditure and firm performance effects are stronger amongst firms that were subject to a higher acceptance threshold. ${ }^{21}$

69. Second, we consider the role of worker attributes aggregated at the firm level. We consider different dimensions and consider their average per firm in the year when they submit their FIG application. We then split firms in terms of the resulting median value of the resulting distribution or an alternative threshold. Figure A.25 considers the nine years of schooling threshold that corresponds to basic and compulsory schooling since the early 1990s until recently (several firms still happen to employ a large share of their workforce with lower levels of schooling, in particular those with an older workforce). We find again the same range of qualitative effects in the two types of firms but stronger effects amongst lowschooling workforce firms, including in terms of employment. This result may suggest that training can add more value when delivered to individuals with lower schooling levels.

70. When considering the case of age, splitting the data at the median age of 38.25 , we find similar positive findings across all variables for both types of firms, but stronger effects for firms with older workforces (typically also firms with lower schooling). Finally, Figure A.27 presents the case of gender, comparing firms with a relatively high share of women (above $33 \%$ in our data) and those with a lower

21 We also consider the case of exports, comparing firms that export in the year when they apply to FIG and those that do not export at that time (and again using the full data set). The results - Figure A.24 - again indicate that FIG effects emerge in both types of firms, without large differences between the two groups of firms. 
share. Again, we obtain very similar results, for both types of firms, as in our benchmark findings based on the full sample.

\section{Concluding remarks}

71. This paper estimated the effects of employee training on firm performance using a quasiexperimental approach. We draw on variation in training hours and expenditure across firms driven by a large training grants programme supported by the European Social Fund, FIG, and rich longitudinal data sets comparing successful and unsuccessful applicants. First, we find that deadweight losses are limited, at no more and possibly much less than $24 \%$. Second, several dimensions of firm performance are impacted positively by the increase in training driven by the programme: sales, value added, employment, productivity, and exports all increase following the additional training conducted by firms. An exception is, however, profits, for which we cannot estimate precise enough effects, perhaps because of measurement error in that (accounting) variable.

72. Moreover, the magnitude of the firm performance effects is typically economically large, at around $10 \%$, as in the cases of sales, gross value added, and sales per worker. In the cases of other variables, the effects are smaller but still sizable, at around $5 \%$ (employment and firm survival), at least in some periods. Exports are also positively affected but these effects are less precise and typically significant only over a small number of years. Firm survival is also positively affected by training.

73. We also conducted a number of checks that we found to further support the robustness of our findings - while also raising a number of questions for further research. We highlight three examples. First, we decomposed our novel employment effects of training presented here and found that they are driven both by increased hires and reduced separations, with a stronger contribution from the latter. This result suggests that training grants can also play a role of an active/passive labour market policy, similar to that of short-time work schemes, in increasing the resilience of existing jobs. This interpretation is further supported by the fact that the many positive effects of FIG, including on employment, are stronger in periods of recession. This finding highlights a novel type of 'lock-in effect', here in the context of employed individuals, in contrast to the training lock-in observed for unemployed jobseekers (Lechner \& Wunsch 2009).

74. At the same time, it is important to note that most applicants to this programme were large firms, which could entail limitations in the external validity of our findings. On the other hand, we found similar results in a robustness check when considering only small firms. A different question, which we do not examine here, concerns the potential for spillovers to other firms (Criscuolo et al. 2019): these could however be negative (involving some form of market stealing) or positive (namely through mobility of trained workers).

75. Second, we did not find significant differences between treated and control firms in the 'before' period in almost all of the large number of potential outcome variables considered. In some cases, we also did not find significant differences in the 'after' period, namely for firm-level wages, despite the positive effects on multiple dimensions of firm performance, including productivity. As mentioned above, this result of no effects on wages does not necessarily imply that the worker-level returns to training are zero since we also found that training has a positive effect both on employment and on hires. These latter two effects may create composition biases as new hires will typically be paid lower wages, depressing the average wage in the firm. This may also explain at least part of the gaps between productivity and wage premiums of training that were presented in previous research (Konings \& Vanormelingen 2015), in which productivity premiums tend to be much larger than the corresponding wage premiums. We plan to investigate this in more detail in future research, drawing on the individual-level dimension of our data. 
76. Finally, we found that training does not have a weaker effect for firms with less educated workforces. In some cases, including employment, the effects of training are even stronger for such firms. While further research here is required, this finding suggests that training may not only have a positive contribution on efficiency - it may also contribute towards the employability of the less educated, with positive effects on equity. This possibility - and the resulting implications regarding the economic and social contributions of training - may be particularly important as the world of work is undergoing major transformations driven by new technologies and the pandemic crisis.

77. What else can other (OECD) countries learn from Portugal's experience examined in this study, on top of the conclusions above? First, training grants appear to be an effective tool to support firms' training and productivity. Even if our empirical analysis could not detect significant effects on profitability, firms (and, indirectly, their workers) appear to clearly benefit from support of this type. Second, programme design may matter. In this case, the programme was demand-led (firms had flexibility in the selection of the type of training to provide). General training, which is portable cross firms, and small firms, which may be less likely to train, received more support. Third, external validity within Portugal and elsewhere may not hold fully. Different results may arise if the grants were made available more widely and not only to firms that applied for such funds and therefore had an interest in pursuing skills-related projects in the first place. The last point may play a critical role in the design of training mandates for firms. If the positive effects of the study apply only in the subset of firms studied here, these training mandates may create inefficiencies in the firms where the payoff is lower or zero. Conversely, if the positive effects presented in the study apply across a broader range of firms, such mandates (or, alternatively, less restrictive 'nudges') towards more training may have a positive social effect and should be introduced in more countries or widened further. 


\section{References}

Abramovsky, L., Battistin, E., Fitzsimons, E., Goodman, A. \& Simpson, H. (2011), 'Providing employers with incentives to train low-skilled workers: Evidence from the UK employer training pilots', Journal of Labor Economics 29(1), 153-193.

Almeida, R. \& Carneiro, P. (2009), 'The return to firm investments in human capital', Labour Economics 16(1), 97-106.

Barrett, A. \& O'Connell, P. (2001), 'Does training generally work? The returns to in-company training', Industrial and Labor Relations Review 54(3), 647-662.

Becker, S. O., Egger, P. H. \& von Ehrlich, M. (2013), 'Absorptive capacity and the growth and investment effects of regional transfers: A regression discontinuity design with heterogeneous treatment effects', American Economic Journal: Economic Policy 5(4), 29-77.

Bloom, N., Manova, K., Van Reenen, J., Sun, S. \& Yu, Z. (2021), 'Trade and management', Review of Economics and Statistics, forthcoming.

Brunello, G., Comi, S. L. \& Sonedda, D. (2012), 'Training subsidies and the wage returns to continuing vocational training', Labour Economics 19(3), 361-372.

Brunello, G. \& Wruuck, P. (2020), Employer provided training in Europe: Determinants and obstacles, European Investment Bank Discussion Paper 2020/03.

Cahuc, P., Kramarz, F. \& Nevoux, S. (2018), When Short-Time Work Works, IZA Discussion Paper 11673.

Card, D., Kluve, J. \& Weber, A. (2010), 'Active labour market policy evaluations: A meta-analysis', Economic Journal 120(548), F452-F477.

Cockx, B., Lechner, M. \& Bollens, J. (2020), 'Priority to unemployed immigrants? A causal machine learning evaluation of training in Belgium', arXiv 1912.12864.

Criscuolo, C., Martin, R., Overman, H. G. \& Van Reenen, J. (2019), 'Some causal effects of an industrial policy', American Economic Review 109, 48-85.

Dauth, C. (2016), 'Regional discontinuities and the effectiveness of further training subsidies for lowskilled employees', Industrial and Labor Relations Review 73(5), 11471184.

Dostie, B. (2018), 'The impact of training on innovation', Industrial and Labor Relations Review 71(1), 64-87.

Fialho, P., Quintini, G. \& Vandeweyer, M. (2019), Returns to different forms of job-related training, OECD Social, Employment and Migration Working Paper 231, OECD, Paris.

Goerlitz, K. (2010), 'The effect of subsidizing continuous training investments. Evidence from German establishment data', Labour Economics 17(5), 789-798.

Goerlitz, K. \& Tamm, M. (2016), 'The returns to voucher-financed training on wages, employment and job tasks', Economics of Education Review 52, 51-62.

Goux, D. \& Maurin, E. (2000), 'Returns to firm provided training: evidence from French worker-firm matched data', Labour Economics 7, 1-19. 
Hidalgo, D., Oosterbeek, H. \& Webbink, D. (2014), 'The impact of training vouchers on low-skilled workers', Labour Economics 31(C), 117-128.

Holzer, H., Block, R., Cheatham, M. \& Knott, J. H. (1993), 'Are training subsidies for firms effective? The Michigan experience', Industrial and Labor Relations Review 46(4), 625-636.

Howell, S. T. (2017), 'Financing innovation: Evidence from R\&D grants', American Economic Review 107(4), 1136-64.

Jones, D., Molitor, D. \& Reif, J. (2019), 'What Do Workplace Wellness Programs Do? Evidence from the Illinois Workplace Wellness Study', Quarterly Journal of Economics 134(4), 1747-1791.

Konings, J. \& Vanormelingen, S. (2015), 'The impact of training on productivity and wages: Firm-level evidence', Review of Economics and Statistics 97(2), 485-497.

Krueger, A. \& Rouse, C. (1998), 'The effect of workplace education on earnings, turnover, and job performance', Journal of Labor Economics 16(1), 61-94.

Lechner, M. (2011), 'The estimation of causal effects by difference-in-difference methods', Foundations and Trends in Econometrics 4(3), 165-224.

Lechner, M. \& Wunsch, C. (2009), 'Are training programs more effective when unemployment is high?', Journal of Labor Economics 27(4), 653-692.

Leuven, E. (2005), 'The economics of private sector training: A survey of the literature', Journal of Economic Surveys 19(1), 91-111.

Leuven, E. \& Oosterbeek, H. (2004), 'Evaluating the effect of tax deductions on training', Journal of Labor Economics 22(2), 461-488.

Leuven, E. \& Oosterbeek, H. (2008), 'An alternative approach to estimate the wage returns to privatesector training', Journal of Applied Econometrics 23(4), 423-434.

Lyons, E. (2020), 'The impact of job training on temporary worker performance: Field experimental evidence from insurance sales agents', Journal of Economics \& Management Strategy 29(1), 122 146.

Martins, P. S. (2009), 'Dismissals for Cause: The Difference That Just Eight Paragraphs Can Make', Journal of Labor Economics 27(2), 257-279.

Martins, P. S. (2019), 'The Microeconomic Impacts of Employee Representatives: Evidence from Membership Thresholds', Industrial Relations 58(4), 591-622.

Martins, P. S. \& Thomas, J. P. (2021), 'Collusion and training', University of Edinburgh, mimeo.

McCrary, J. (2008), 'Manipulation of the running variable in the regression discontinuity design: A density test', Journal of Econometrics 142(2), 698-714.

Mehra, A., Langer, N., Bapna, R. \& Gopal, R. (2014), 'Estimating returns to training in the knowledge economy: A firm-level analysis of small and medium enterprises', MIS Quarterly 38(3), 757-772.

Murakozy, B. \& Telegdy, A. (2020), The Effects of EU-Funded Enterprise Grants on Firms and Workers, IZA Discussion Paper 13410.

Schwerdt, G., Messer, D., Woessmann, L. \& Wolter, S. C. (2012), 'The impact of an adult education voucher program: Evidence from a randomized field experiment', Journal of Public Economics 96(78), 569-583.

Westfall, P. \& Young, S. (1993), Resampling-based Multiple Testing: Examples and Methods for p-value Adjustment, John Wiley Sons, Inc.

Zimmert, M. (2020), 'Efficient difference-in-differences estimation with high-dimensional common trend confounding', arXiv 1809.01643.

Zwick, T. (2006), 'The Impact of Training Intensity on Establishment Productivity', Industrial Relations 45(1), 26-46. 


\section{Annex A. Supplementary Figures and Tables}

Figure A.1. Probability of treatment and number of observations by (centred) application score

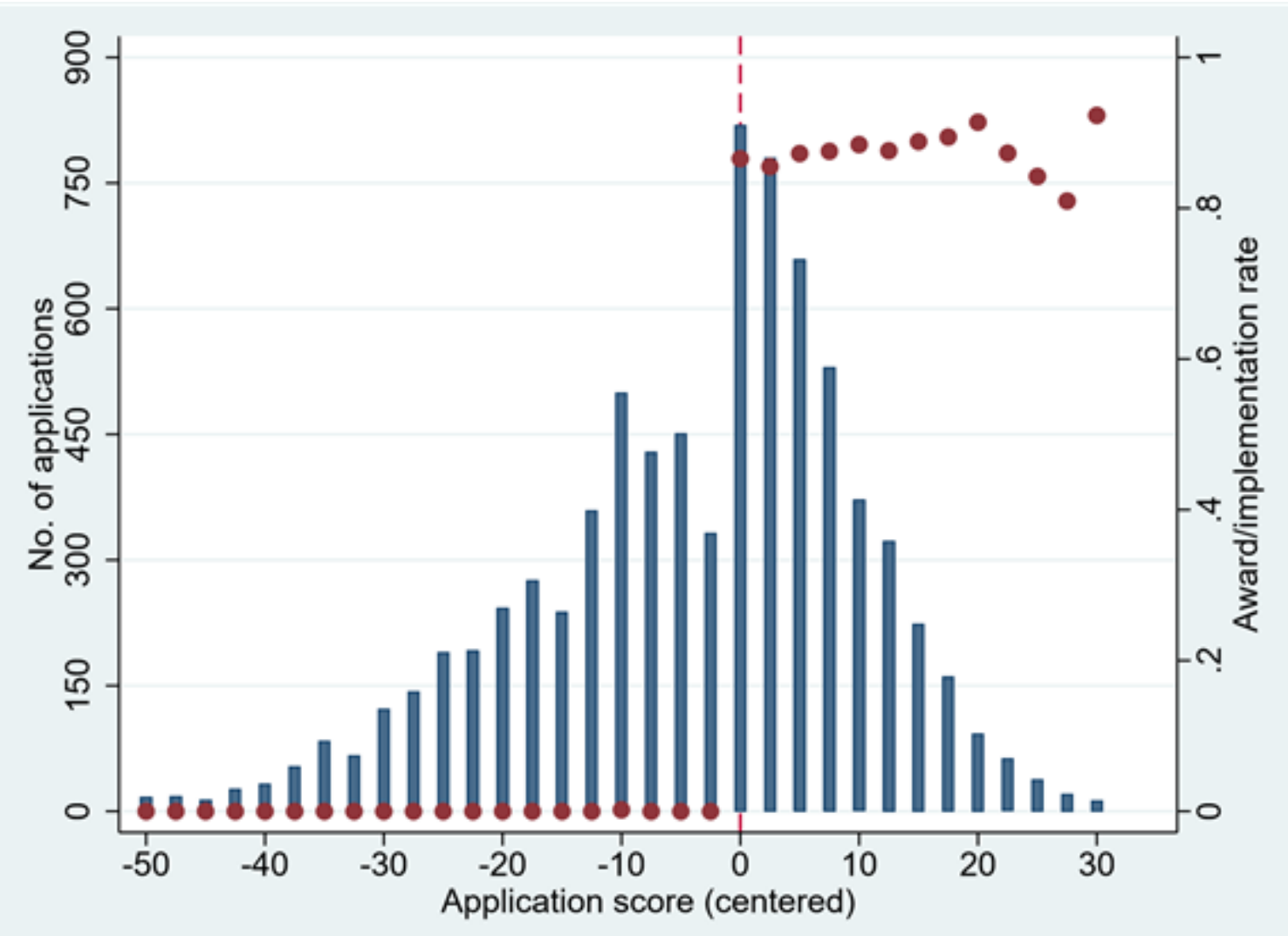

Note: The horizontal axis indicates the (centred) values of the application score. The left vertical axis (and the bars) indicate the number of firms at each application score. The right vertical axis (and the dots) indicate the percentage of firms with each application score that were accepted and implemented their training project. 
36

Figure A.2. McCrary density analysis

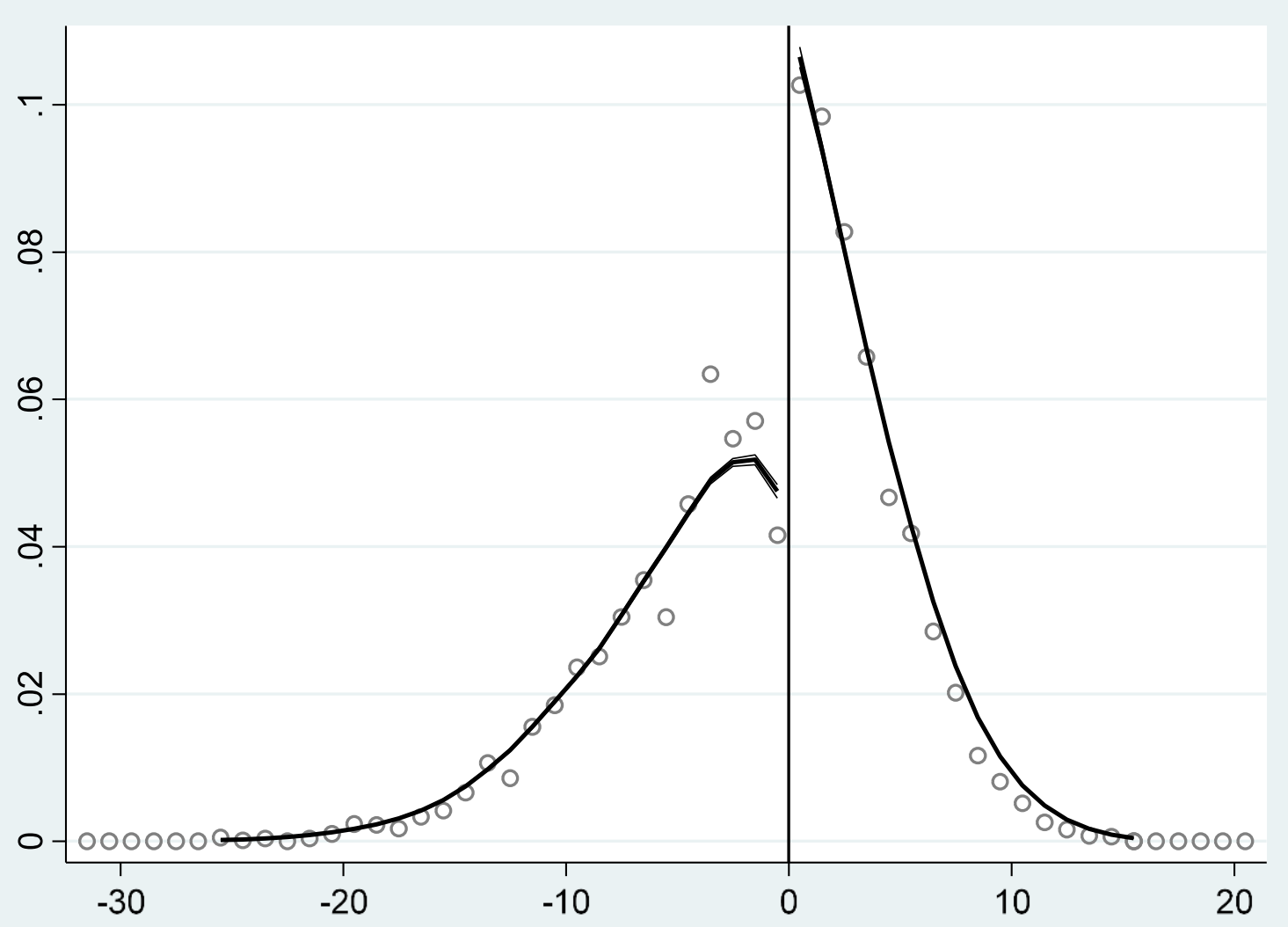

Note: The figure is based on the data underpinning Figure A.1 and the method in McCrary (2008). The scores were divided by 2.5 (the unit used in the original scoring). 
Figure A.3. DID effects: Log non-salary staff expenditure per worker

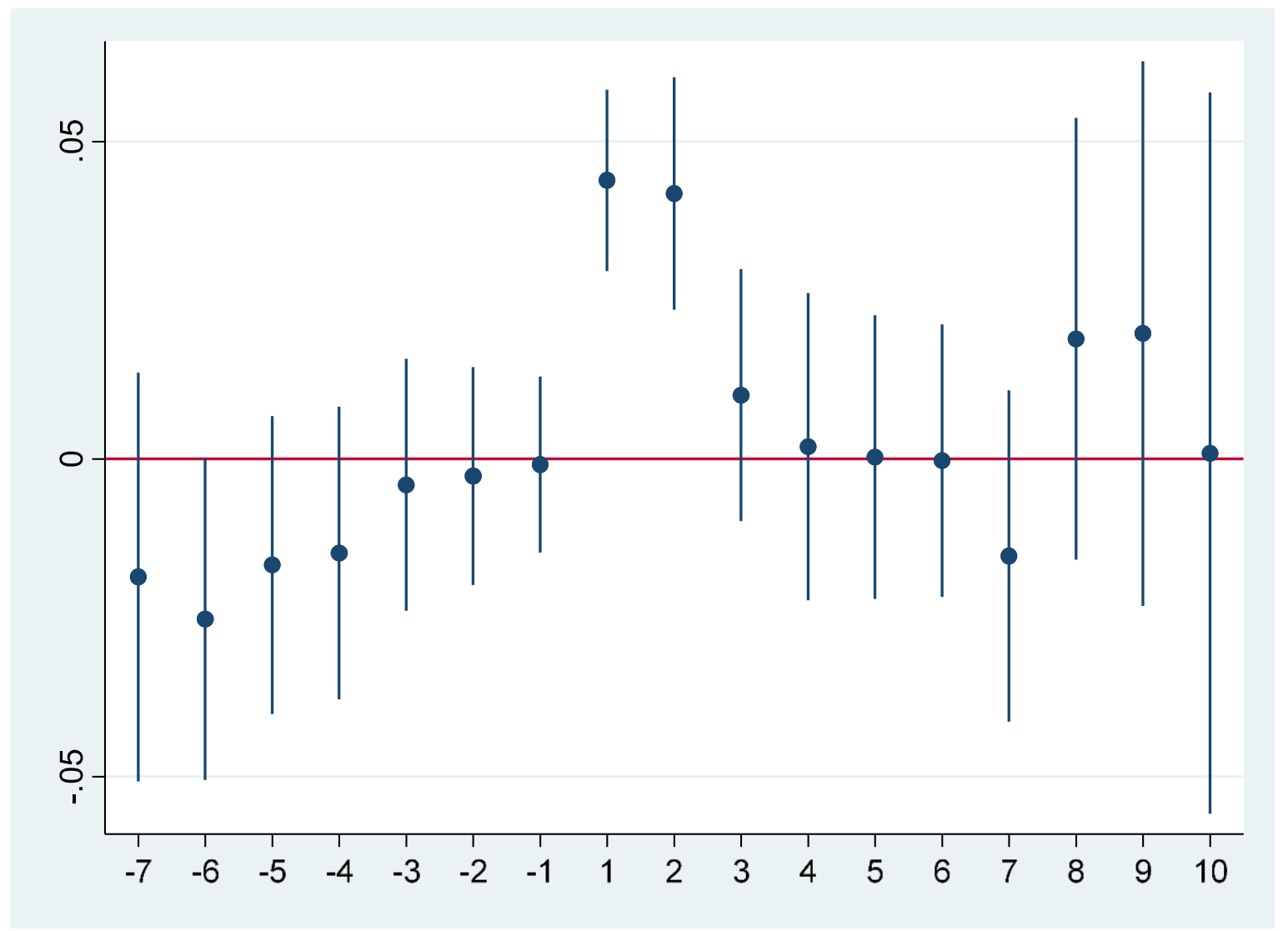

Note: The dependent variable is the log of the ratio between non-salary staff expenditure (SCIE data set) and the total number of workers (QP data set). See notes to Figure 1. 
Figure A.4. DID effects: Log sales (alternative measure)

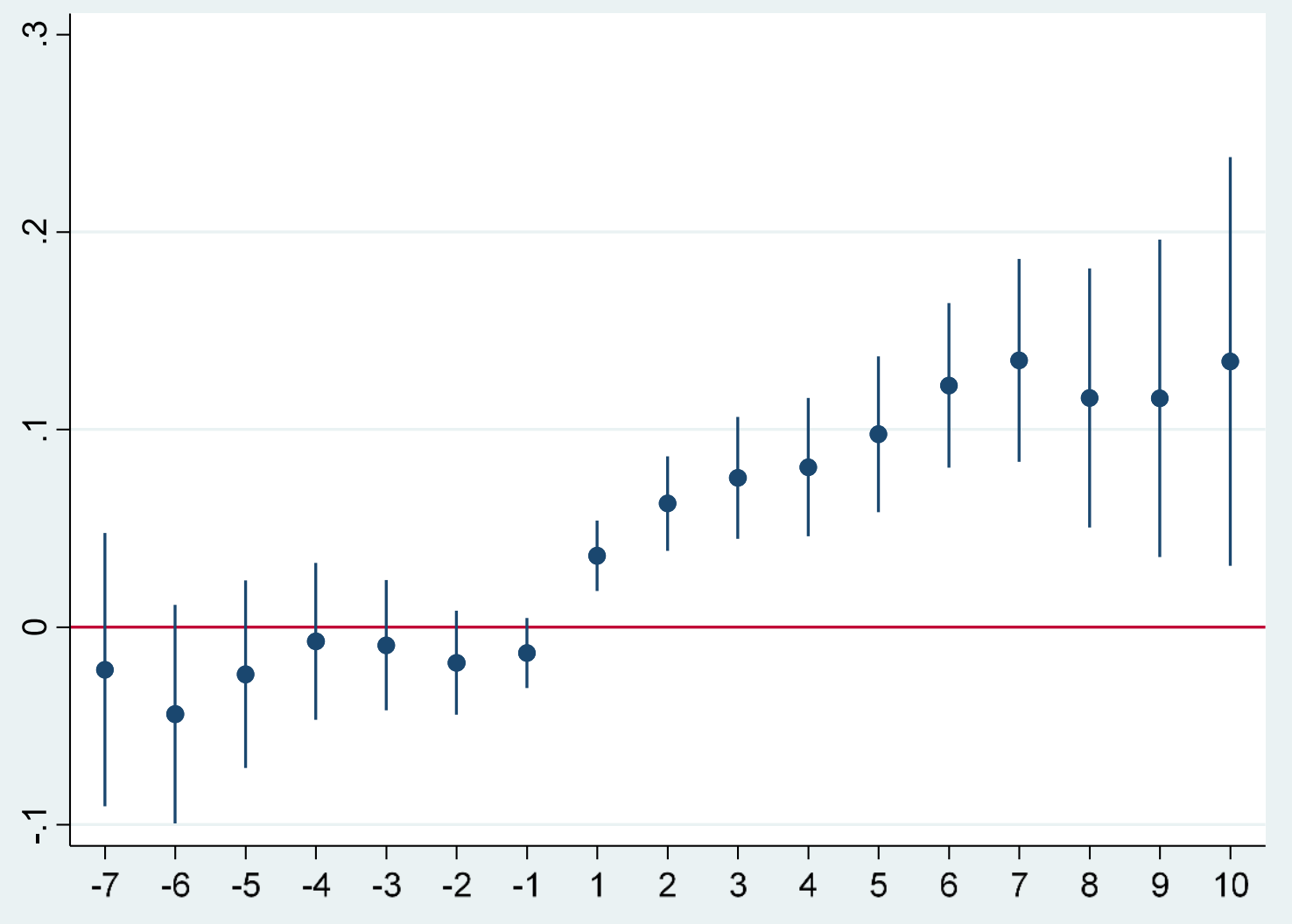

Note: The dependent variable is the log of total sales of each firm (SCIE data set). The number of observations is 106,692. See notes to Figure 1. 
Figure A.5. DID effects: Log gross value added per worker

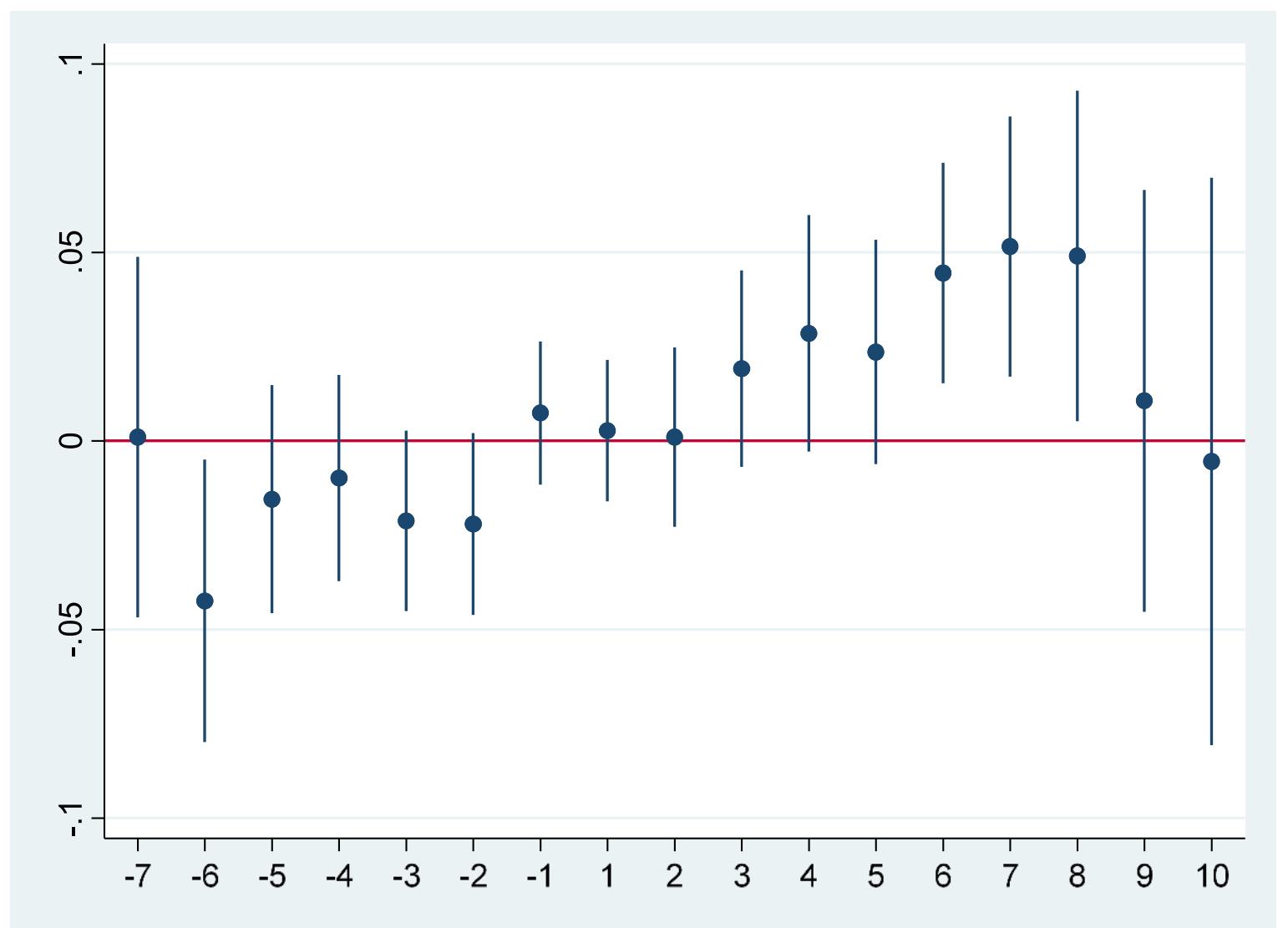

Note: The dependent variable is the log of the ratio between gross value added (SCIE data set) and the total number of workers (QP data set). The number of observations is 103,699 . See notes to Figure 1. 
Figure A.6. DID effects: Job and worker flows

Net job creation rate

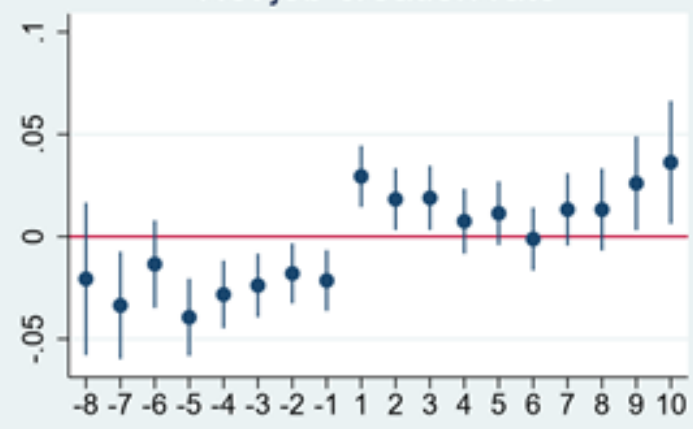

Hiring rate

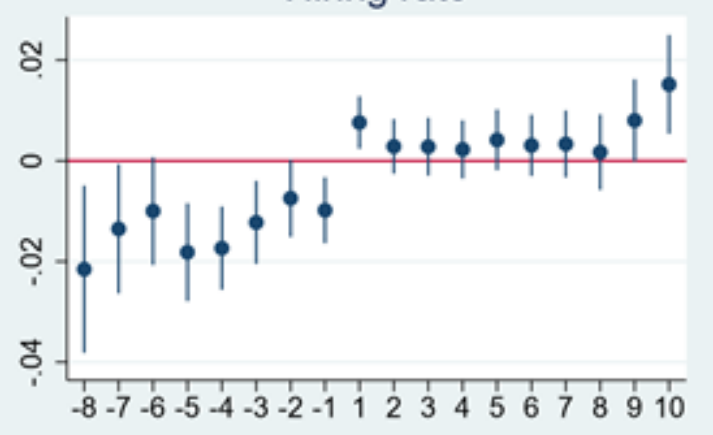

Separation rate

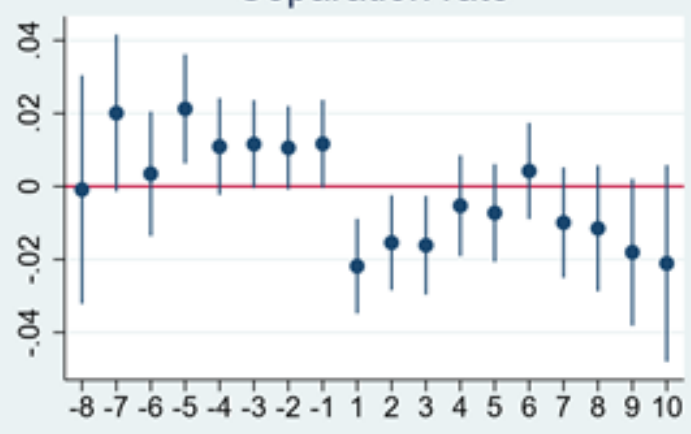

Note: The dependent variables are (clockwise, from top left corner): Net job creation rate (the ratio between the employment change between year $t$ and year $t-1$ and the average employment of both years), the hiring rate (the ratio between the number of workers hired in year $t$ by the average employment of years $t$ and $t-1$ ) and the separation rate (the ratio between the number of workers that left the firm in year $t$ the average employment of years $t$ and $t-1$ ). All variables computed using the QP data. Number of observations: 130,415 . Each figure corresponds to a separate estimation of a difference-in-differences model. 
Figure A.7. DID effects: Worker characteristics
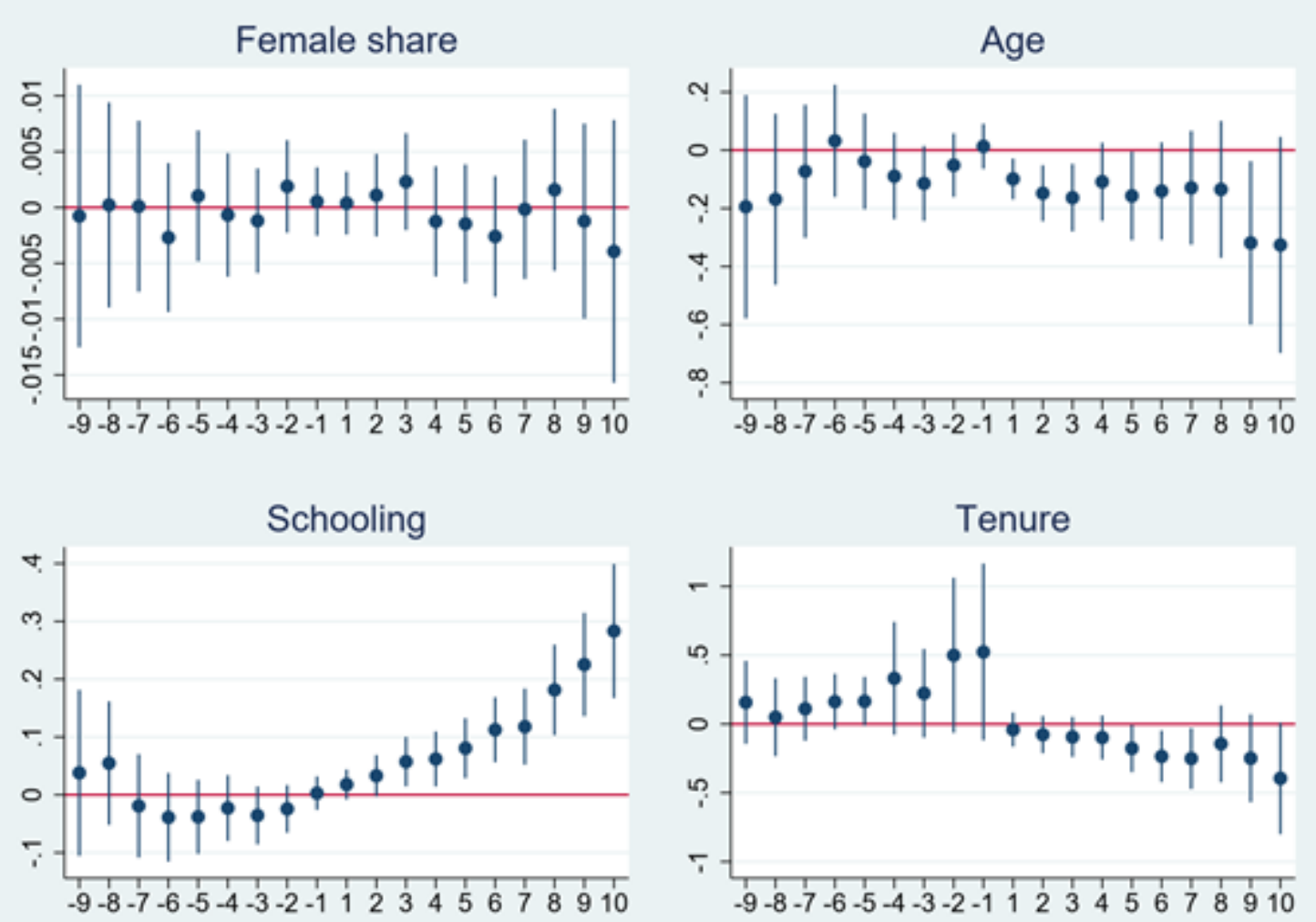

Note: The dependent variables are (clockwise, from top left corner): Percentage of female workers, the average age, the average tenure (years with the firm) and the average schooling years. All variables refer to all employees of each firm in each year. All variables computed using the QP data. See notes to Figure A.6. 
Figure A.8. DID effects: Wages

\section{Base wages}

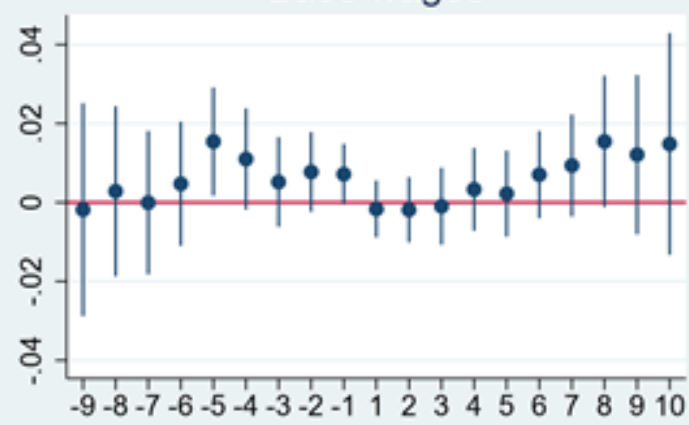

Open-ended contracts

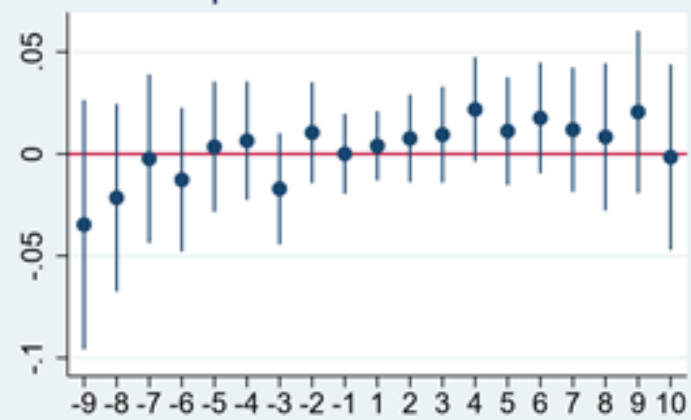

Total wages

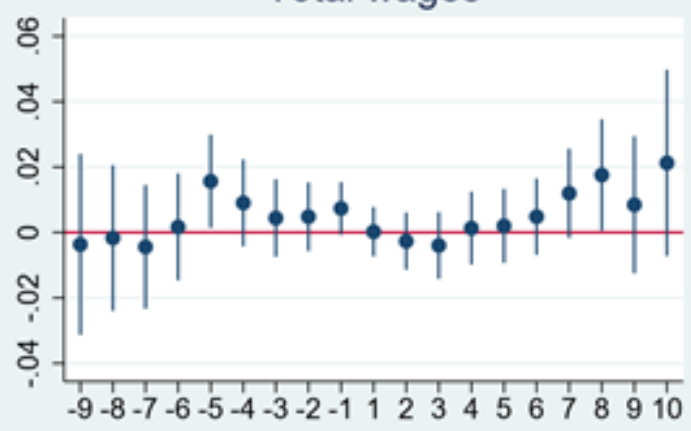

Hours of work

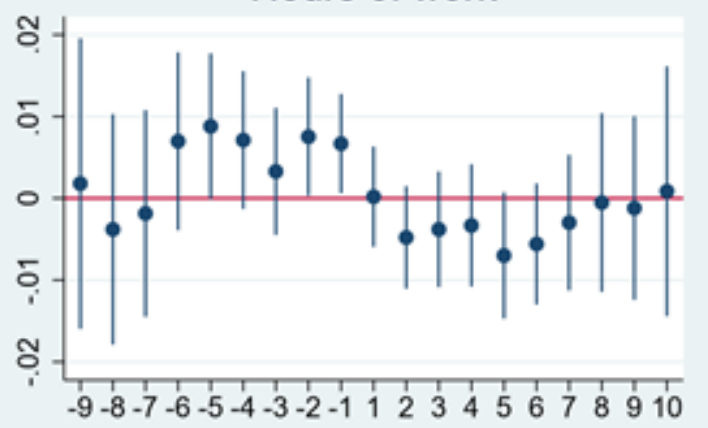

Note: The dependent variables are (clockwise, from top left corner): Average base wage, average total wage, average hours of worker, percentage of open-ended (permanent) employment contracts. All variables refer to all employees of each firm in each year. Number of observations: 132,093. All variables computed using the QP data. See notes to Figure A.6. 
Figure A.9. DID effects: Firm's entry and exit

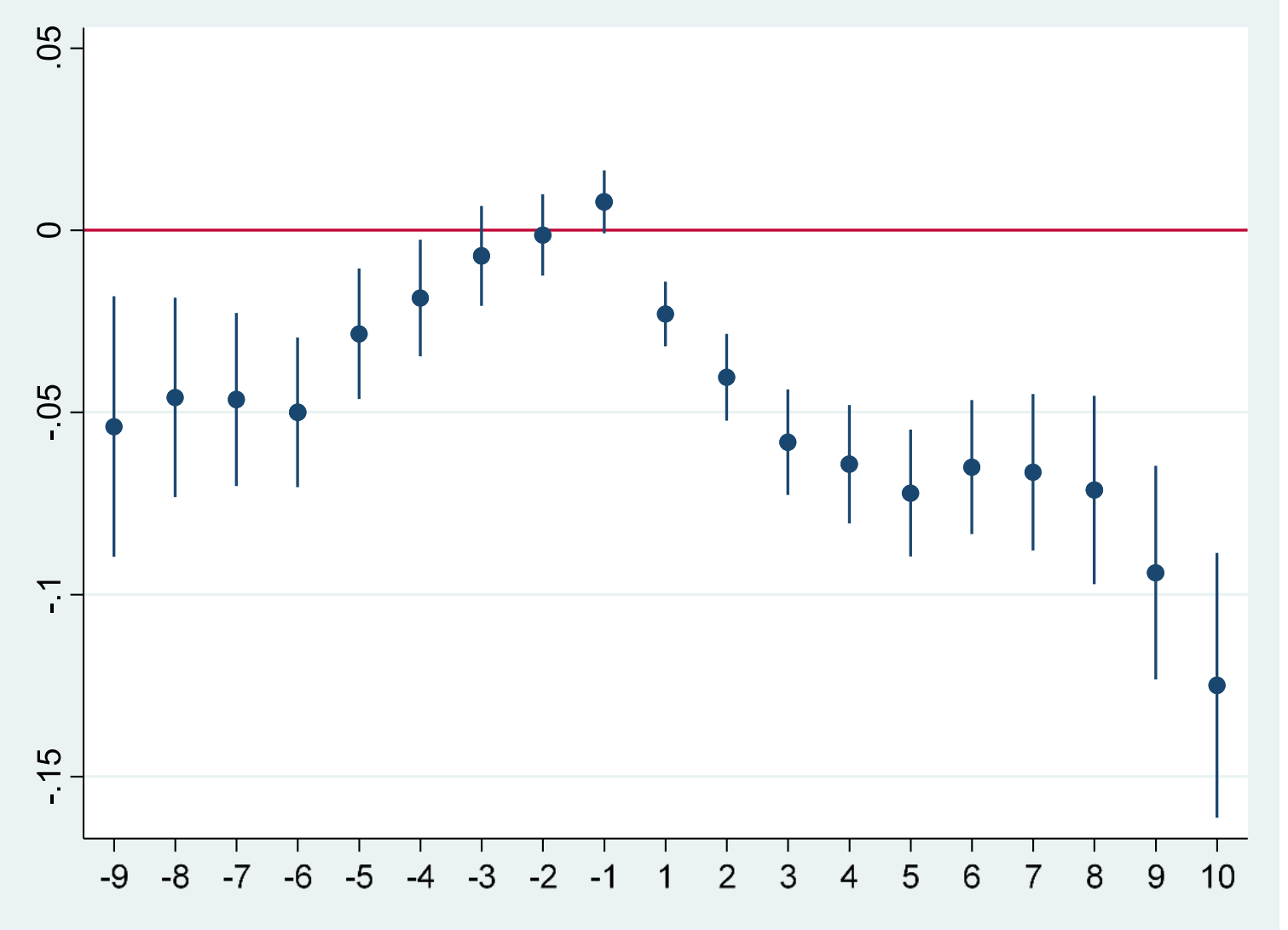

Note: The dependent variable is a dummy equal to one if the firm is not present in a given year (either because it has not entered the market yet - years -1 to -9) or has already left - years 1 to 10). Source: QP data. Number of observations: 155,760. See notes to Figure 1. 
Figure A.10. DID effects: 2007 call
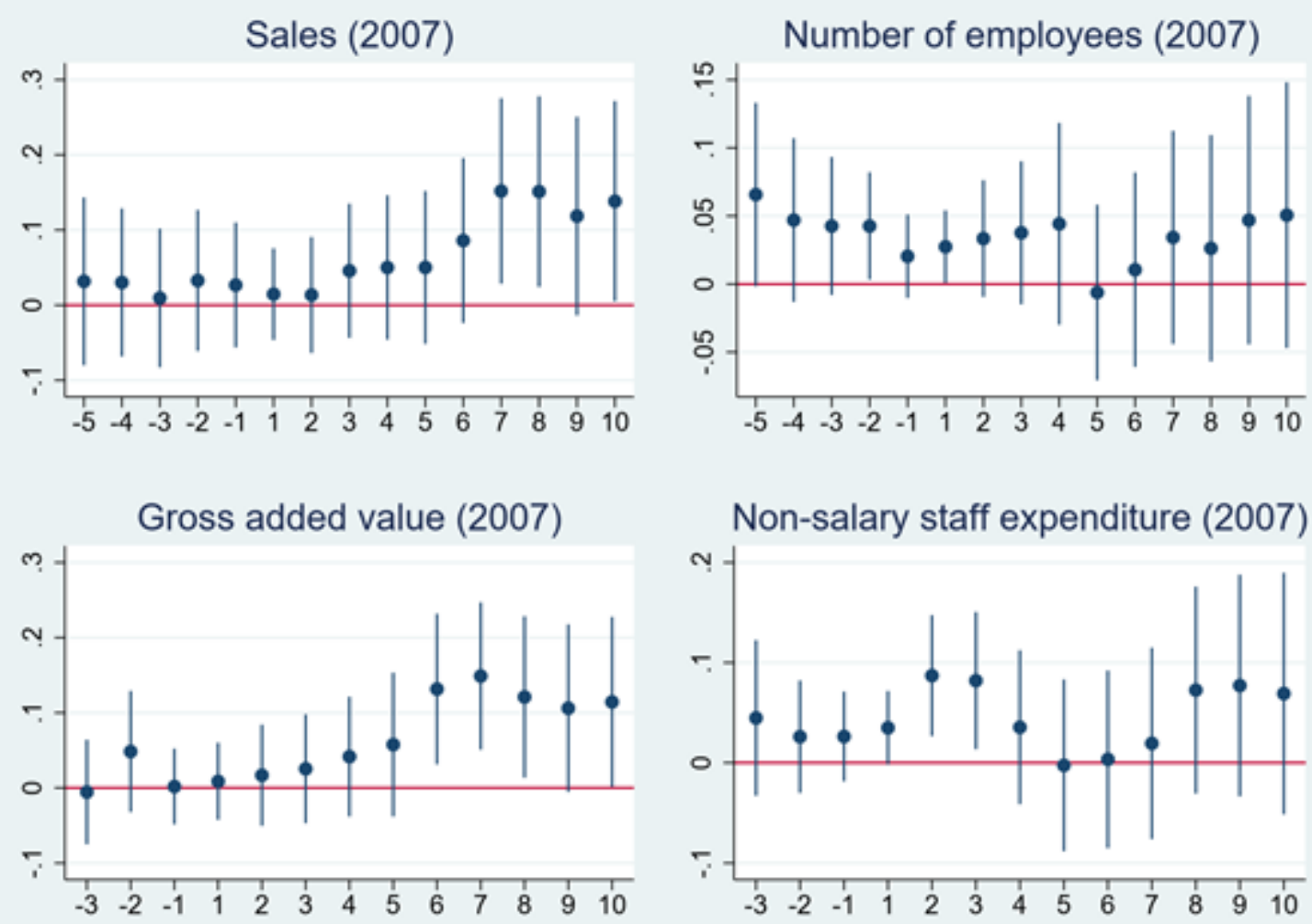

Note: The figures only consider firms that applied to the 2007 call. Year 1 corresponds to 2008 , year -1 corresponds to 2006 , and so on. See notes to Figure A.6. Number of observations: 24,446. 
Figure A.11. DID effects: 2008 call
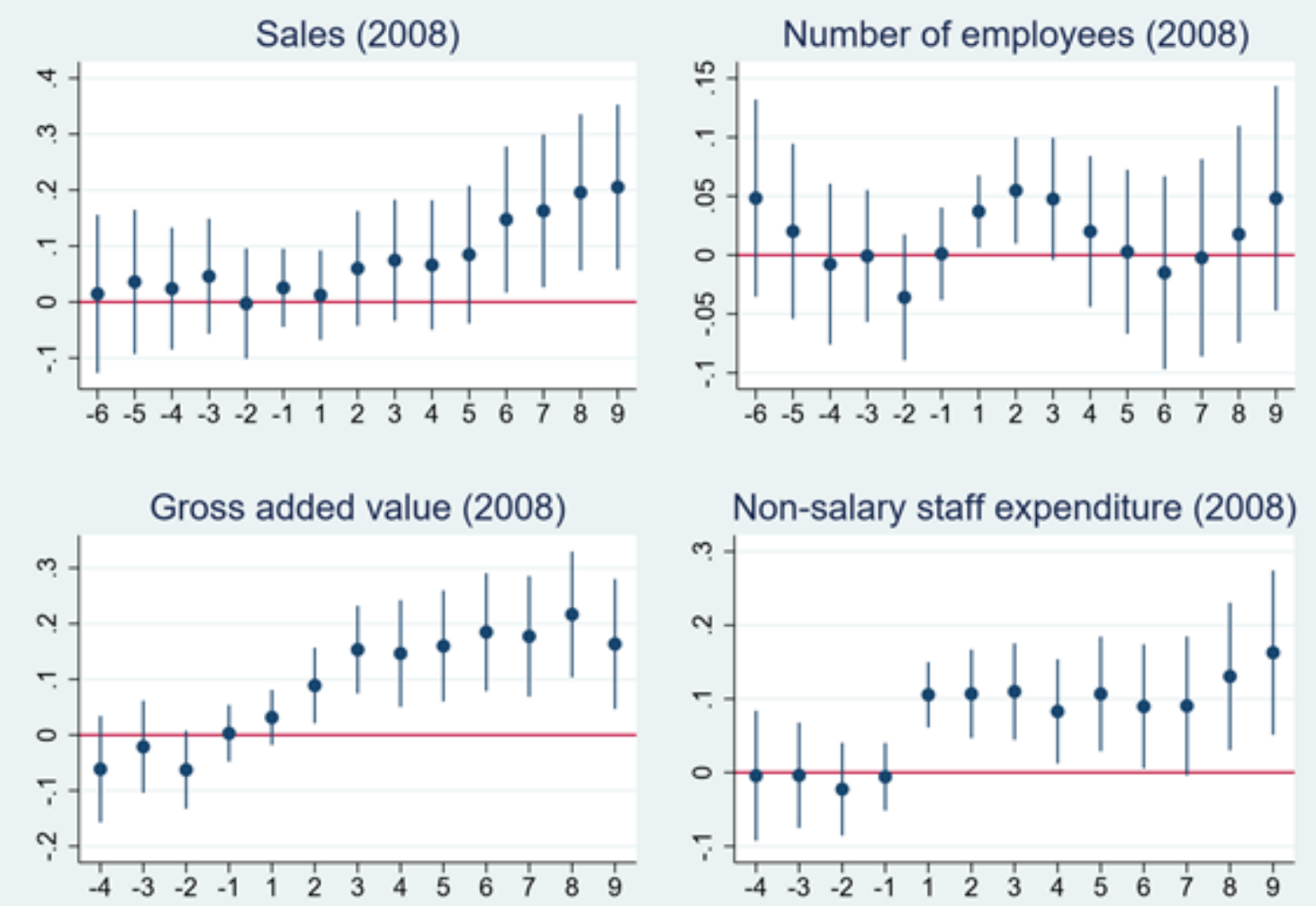

Note: The figures only consider firms that applied to the 2008 call. Year 1 corresponds to 2009 , year -1 corresponds to 2007 , and so on. See notes to Figure A.6. Number of observations: 20,627. 
Figure A.12. DID effects: 2009 call
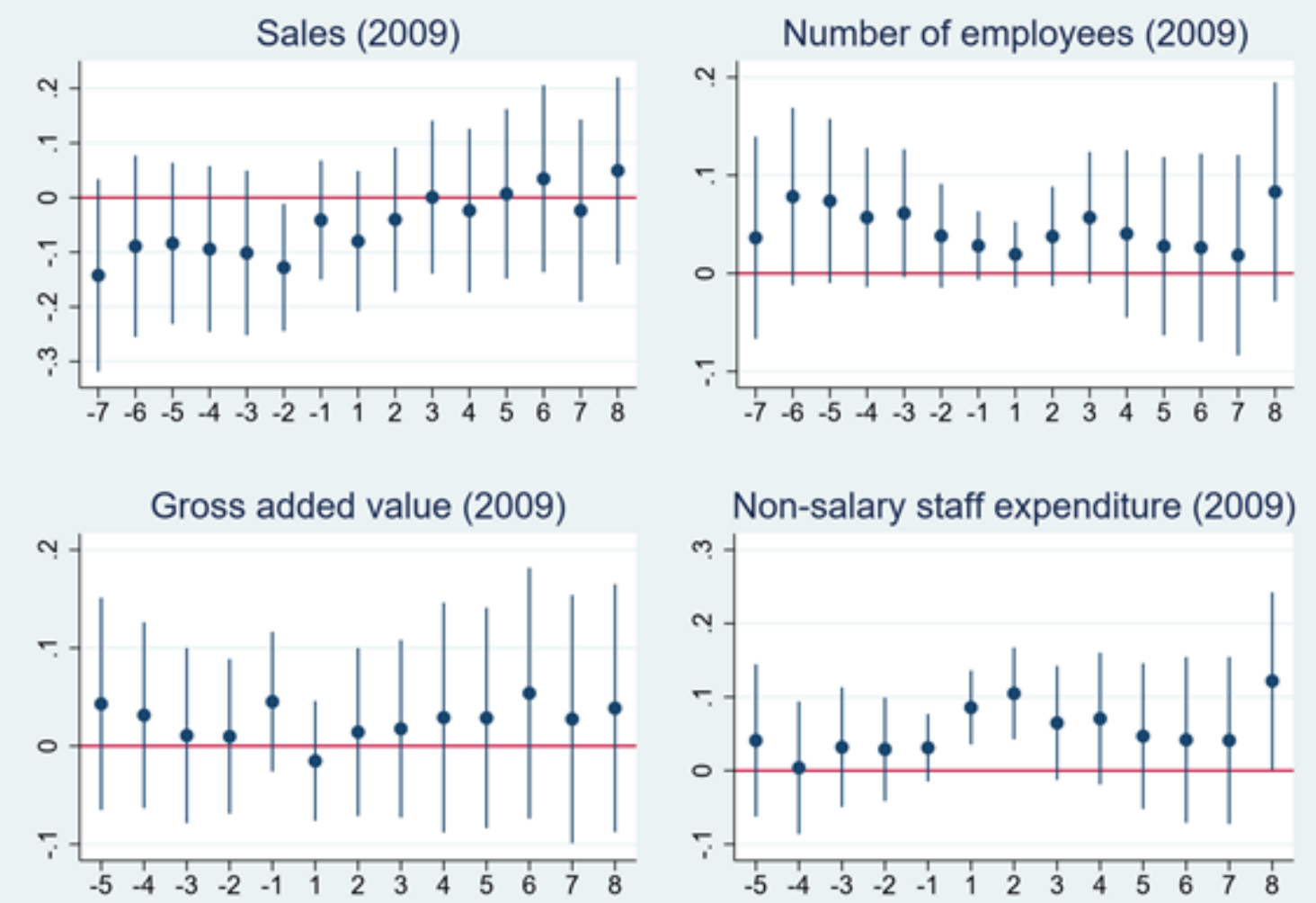

Non-salary staff expenditure (2009)

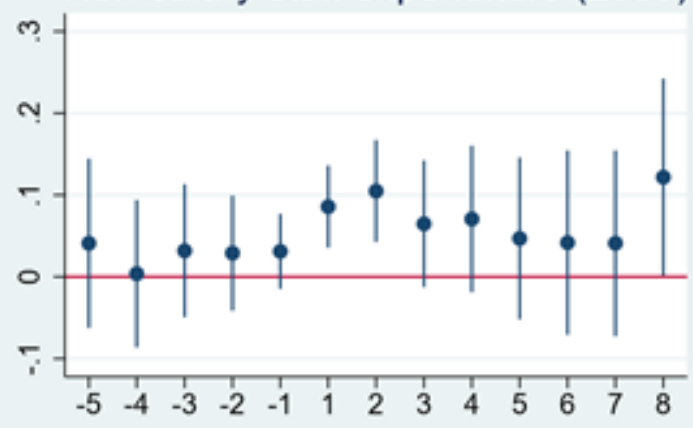

Note: The figures only consider firms that applied to the 2009 call. Year 1 corresponds to 2010 , year -1 corresponds to 2008 , and so on. See notes to Figure A.6. Number of observations: 16,570 . 
Figure A.13. DID effects: 2010 call
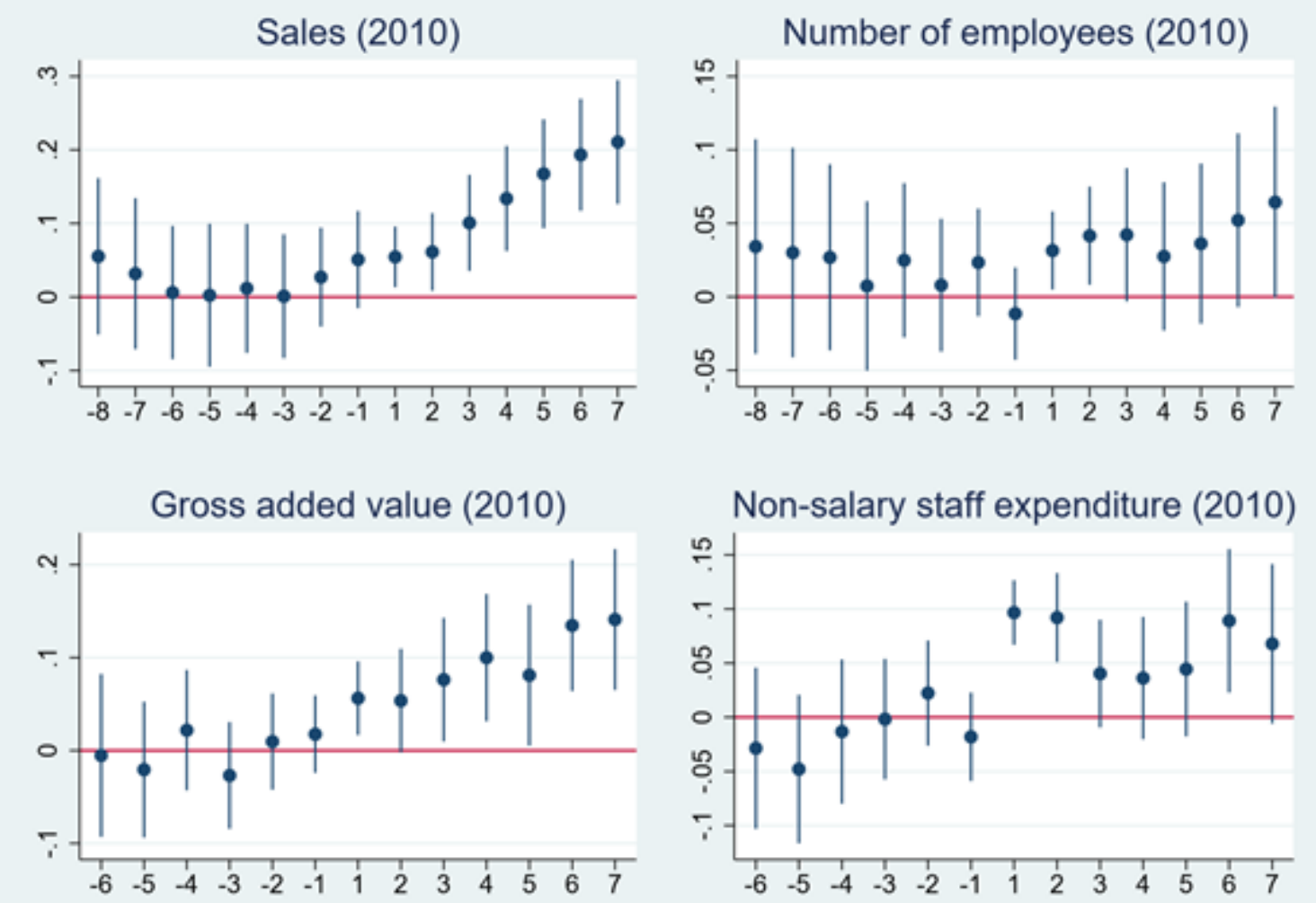

Note: The figures only consider firms that applied to the 2010 call. Year 1 corresponds to 2011 , year -1 corresponds to 2009 , and so on. See notes to Figure A.6. Number of observations: 32,538 . 
Figure A.14. DID effects: 2011 call
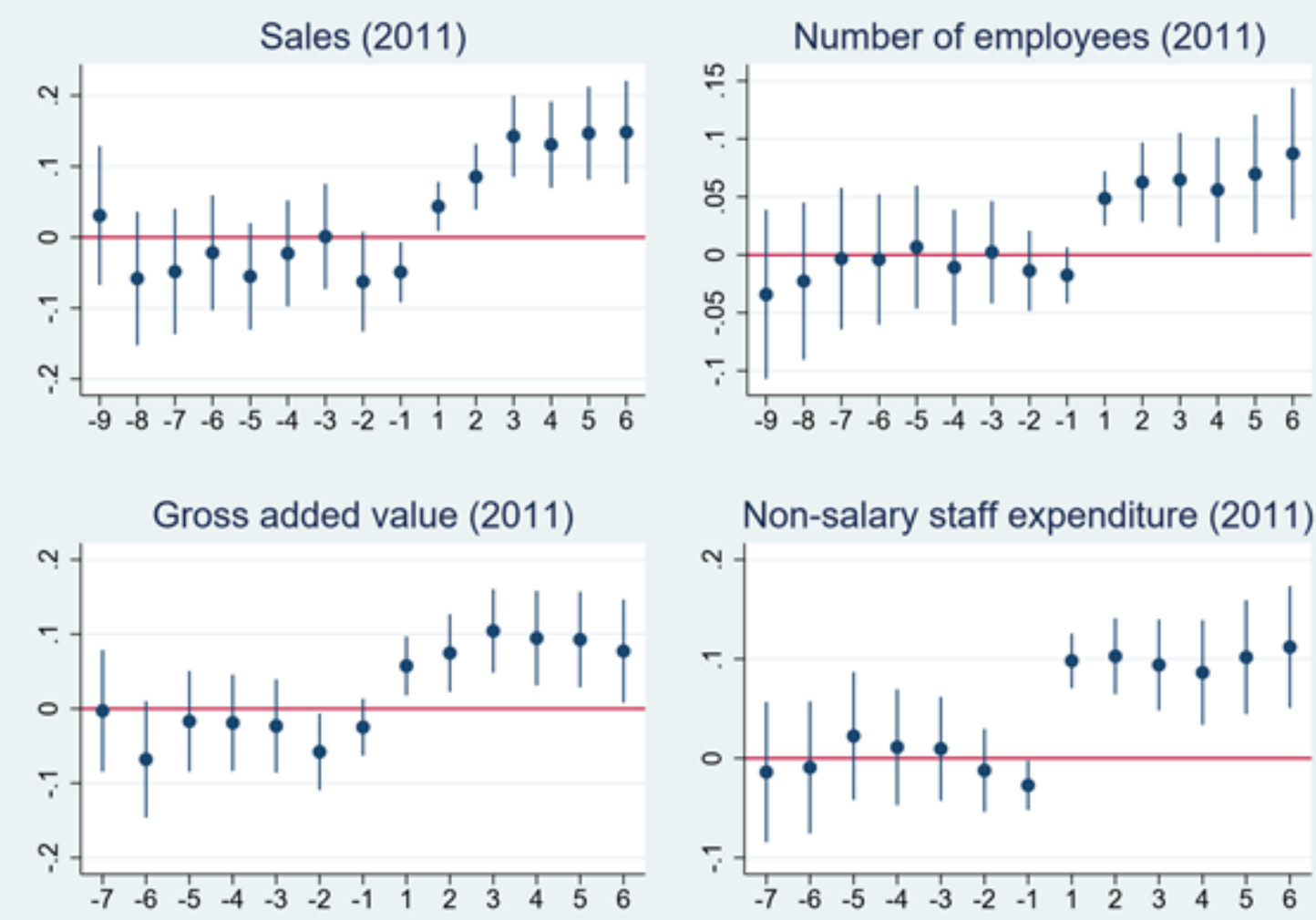

Note: The figures only consider firms that applied to the 2011 call. Year 1 corresponds to 2012, year -1 corresponds to 2010 , and so on. See notes to Figure A.6. Number of observations: 39,000. 
Figure A.15. DID effects: Firms present in all years

Sales

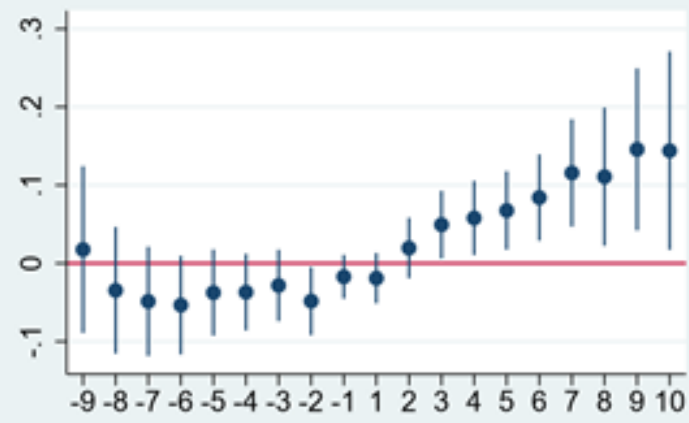

Gross added value

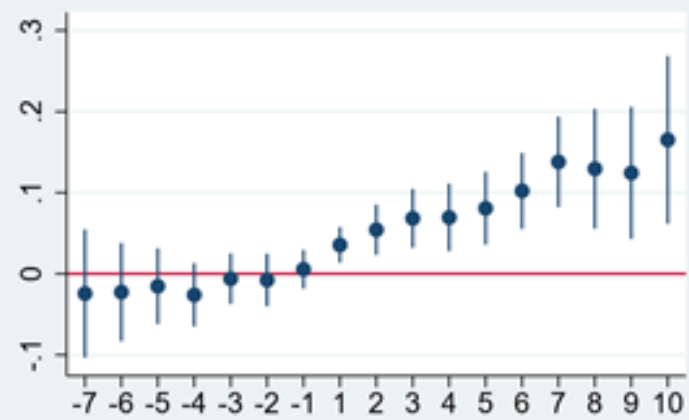

Number of employees

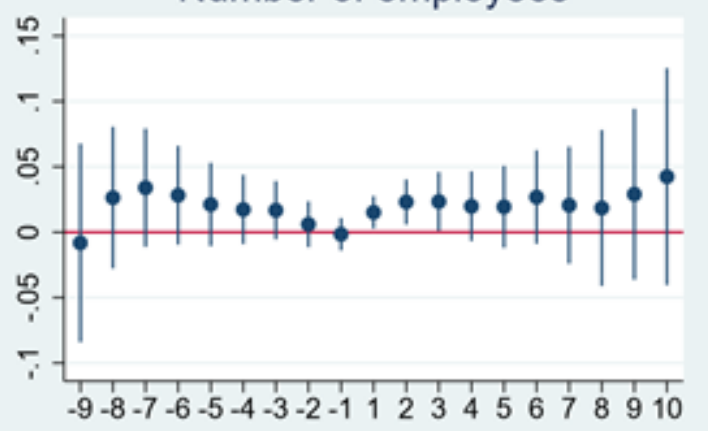

Non-salary staff expenditure

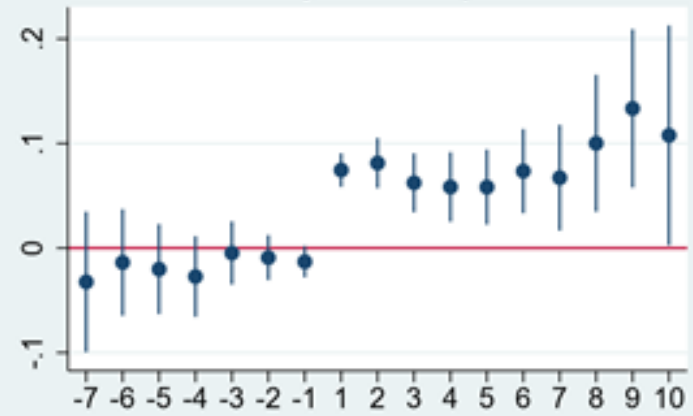

Note: The figures only consider firms that are present in QP in all years between 2002 and 2017. See notes to Figure 1. Number of observations: 58,764 . 
Figure A.16. DID effects: Firms not present in all years

Sales

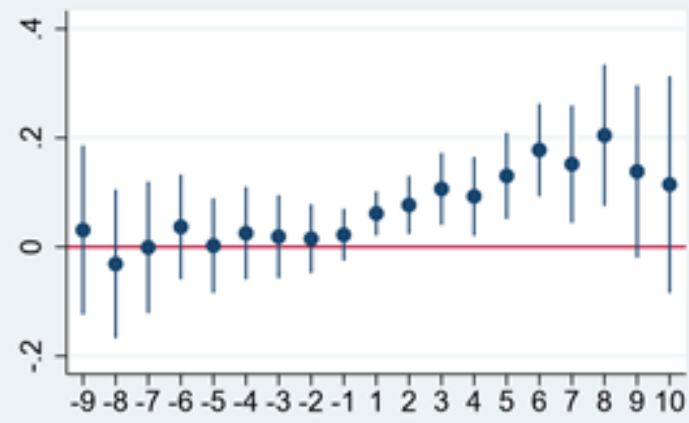

Gross added value

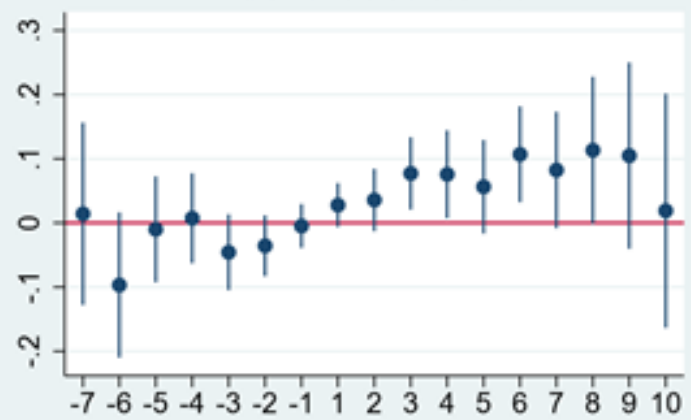

Number of employees

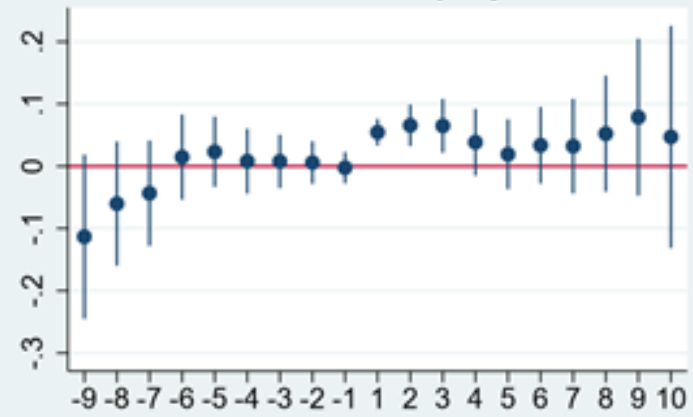

Non-salary staff expenditure

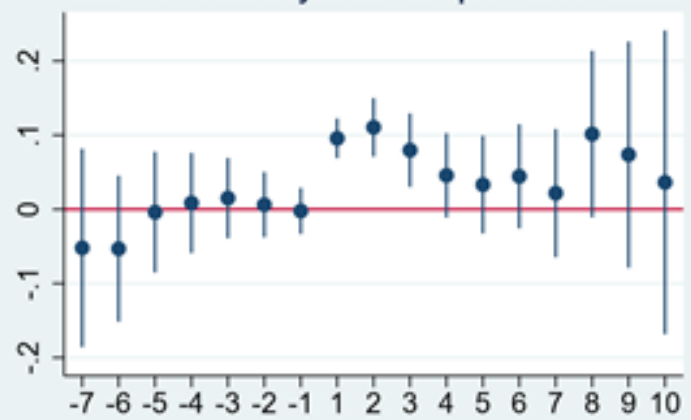

Note: The figures only consider firms that are not present in QP in at least one year between 2002 and 2017. See notes to Figure 1. Number of observations: 47,684 . 
Figure A.17. DID effects: Control group of firms that declined funding

\section{Sales}

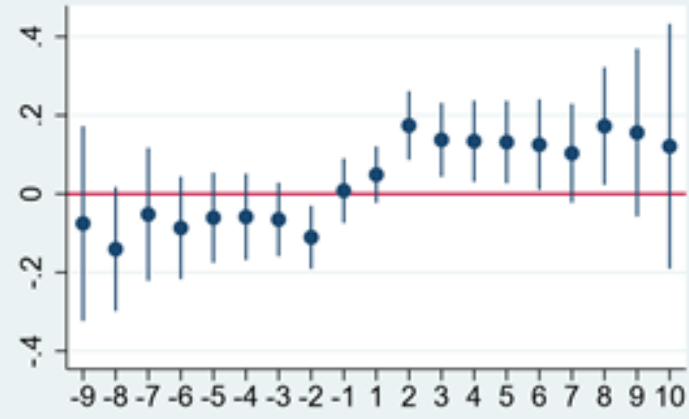

Gross added value

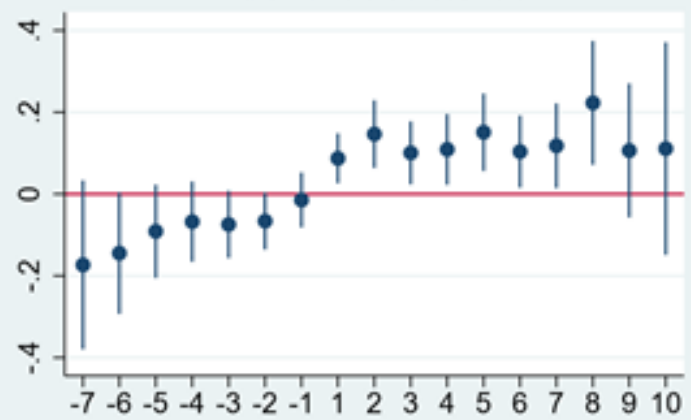

Number of employees

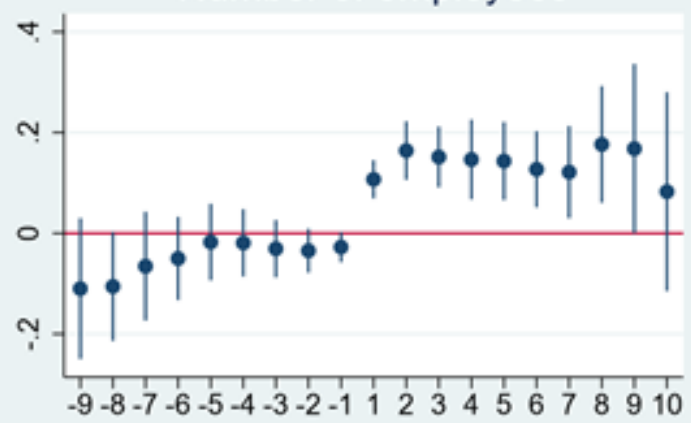

Non-salary staff expenditure

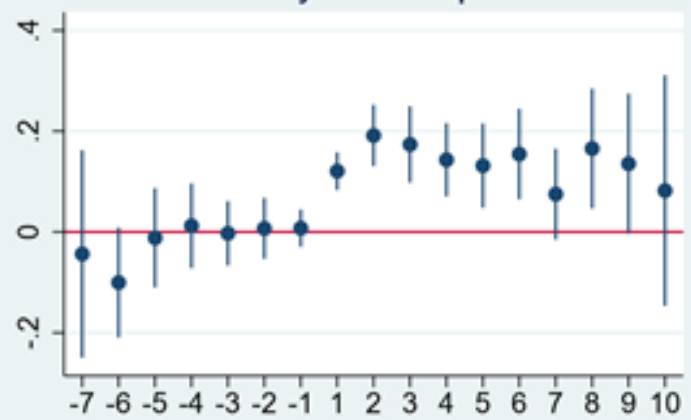

Note: The figures are based on the main sample except that the control group only includes firms that were approved for funding but then declined it. See notes to Figure A.6. Number of observations: 49,407. 


\section{2}

Figure A.18. DID effects - Firms within 5 points of funding threshold

Sales

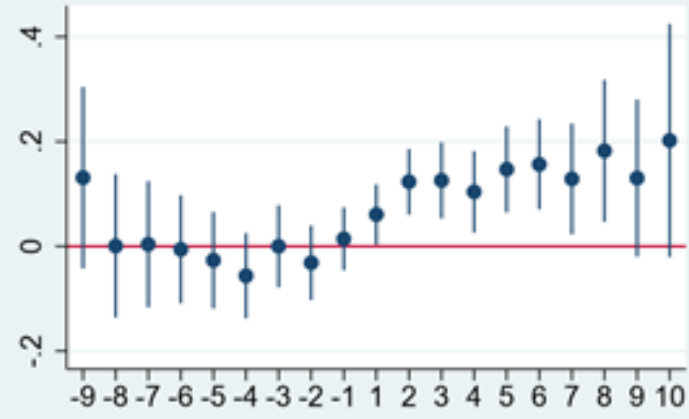

Gross added value

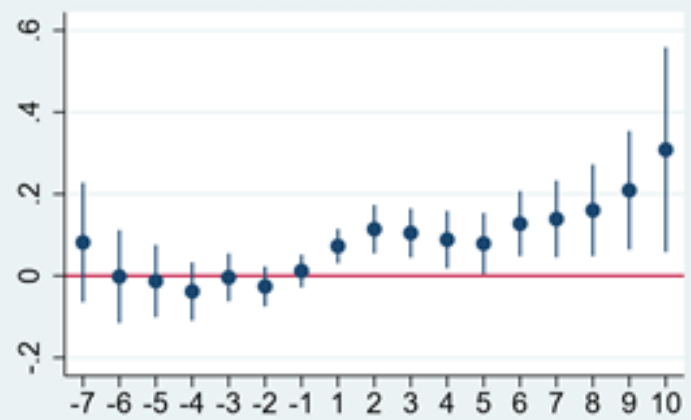

Number of employees

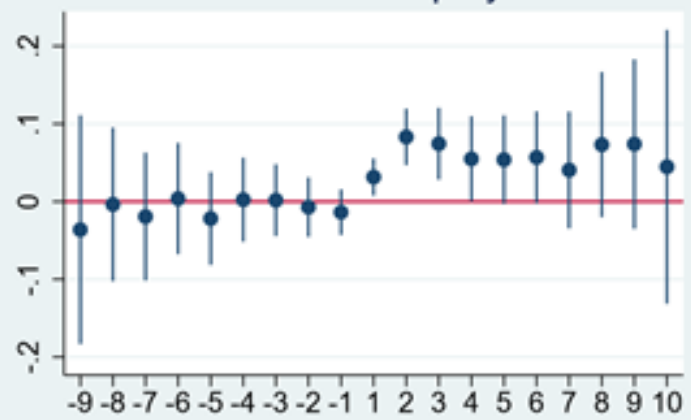

Non-salary staff expenditure

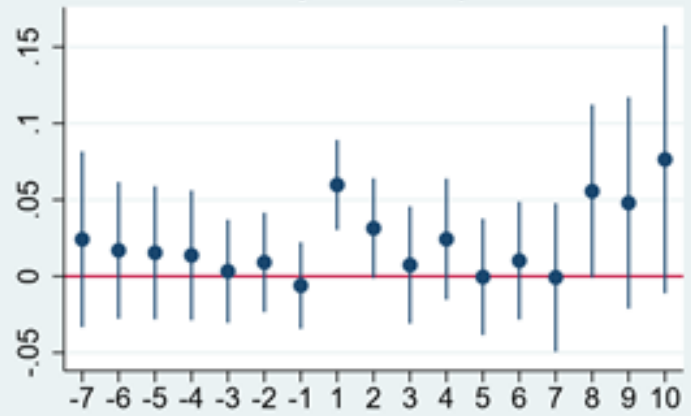

Note: The figures are based on a subset of firms with application scores within 5 points of funding threshold. The number of observations used in the estimations is 33,905 . See notes to Figure A.6. 
Figure A.19. DID effects - Firms outside 2.5 points of funding threshold

\section{Sales}

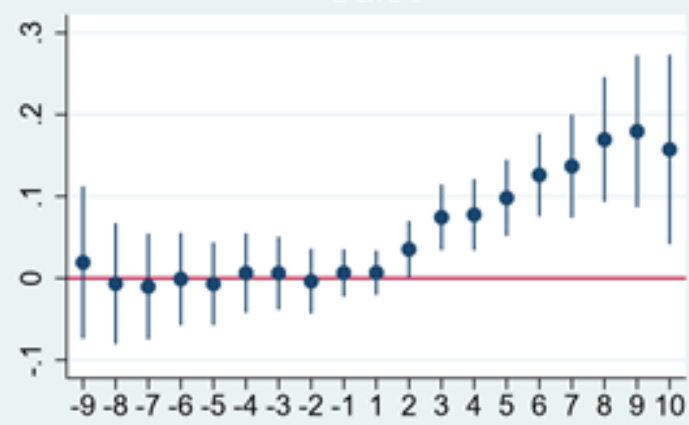

Gross added value

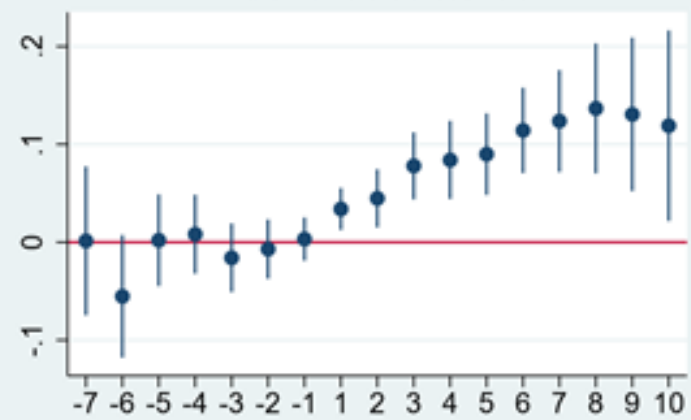

Number of employees

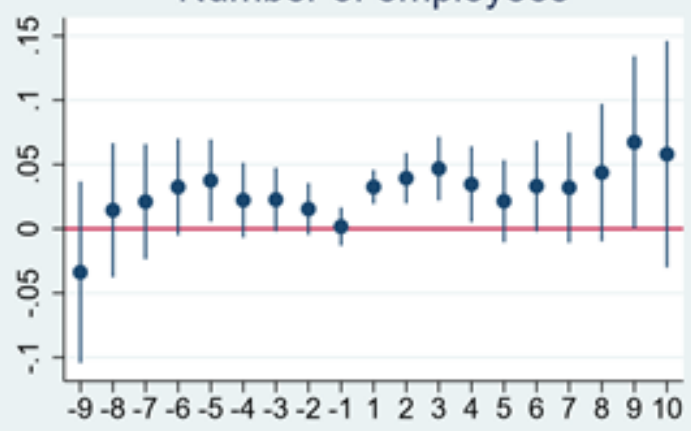

Non-salary staff expenditure

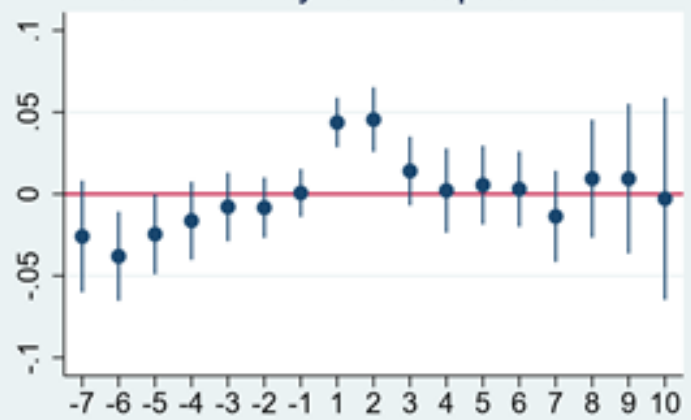

Note: The figures are based on all firms except those with application scores within 2.5 points of funding threshold. The number of observations used in the estimations is 116,914 . See notes to Figure A.6. 
Figure A.20. DID effects - Excluding firms that are rejected more than once

Sales

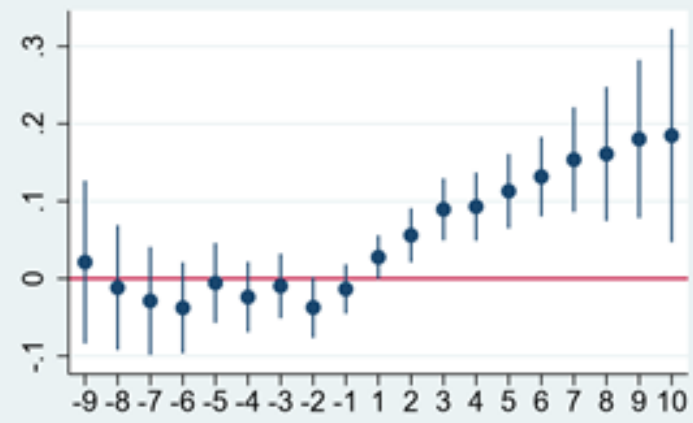

Gross added value

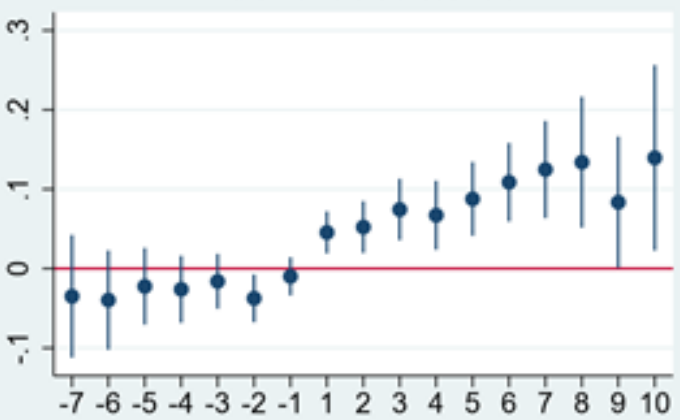

Number of employees

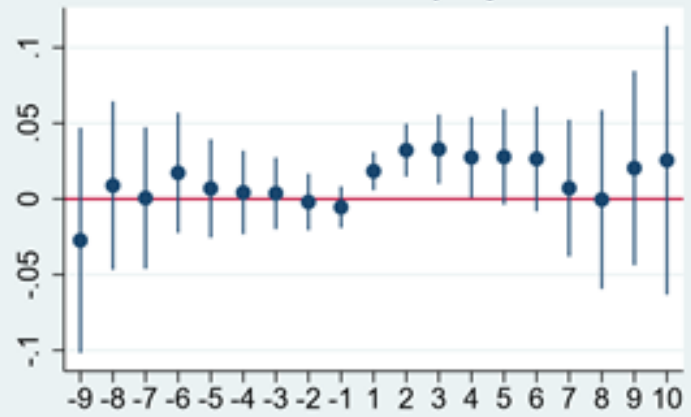

Non-salary staff expenditure

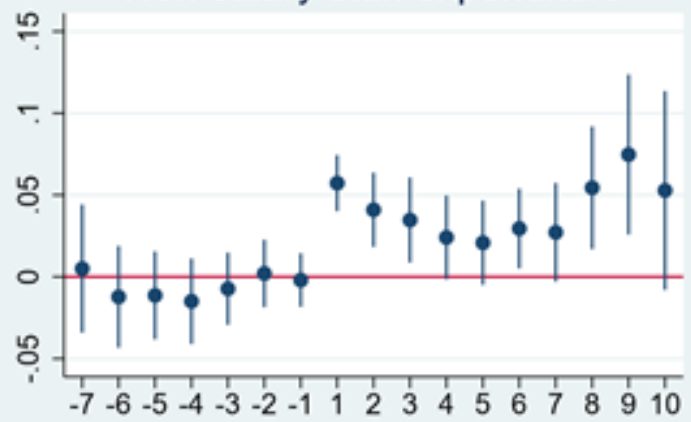

Note: The figures exclude firms that submit multiple applications and are rejected in all occasions. The number of observations used in the estimations is 67,197 . See notes to Figure A.6. 
Figure A.21. DID effects - Heterogeneity: Manufacturing (top) and services (bottom) firms only
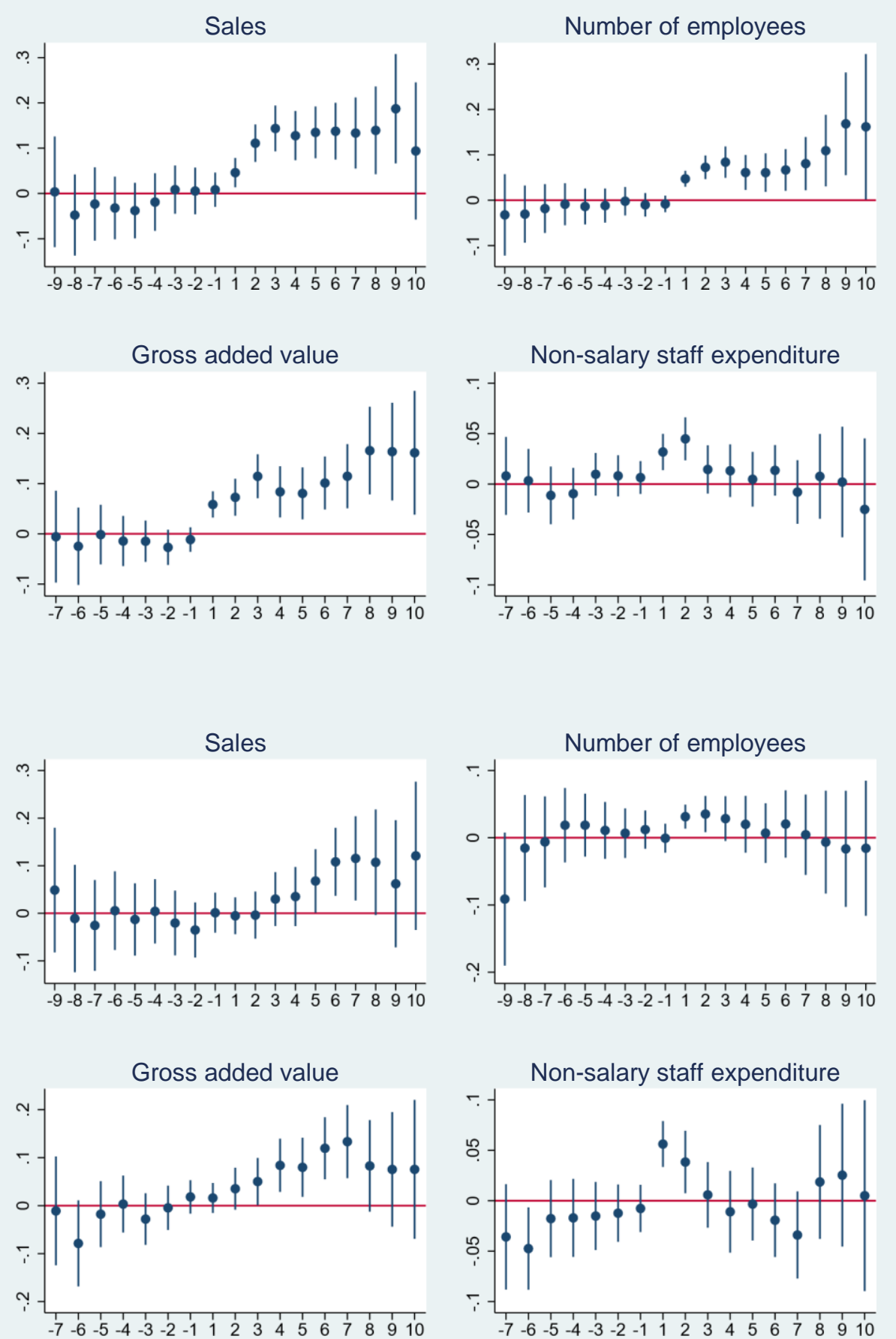

Note: Analysis conducted separately for manufacturing and services sectors. Number of observations: 64,011 and 69,174 , respectively. See notes to Figure A.6. 
56

Figure A.22. DID effects - Heterogeneity: Large firms (top) and smaller firms (bottom) firms only

Sales

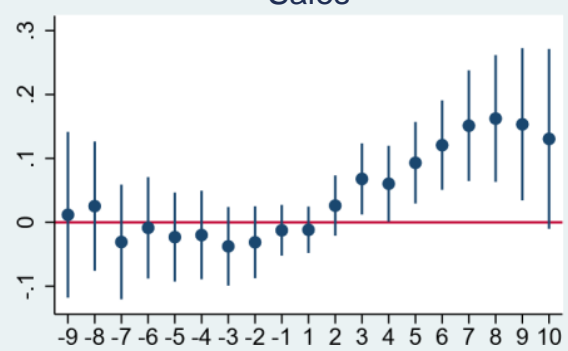

Gross added value

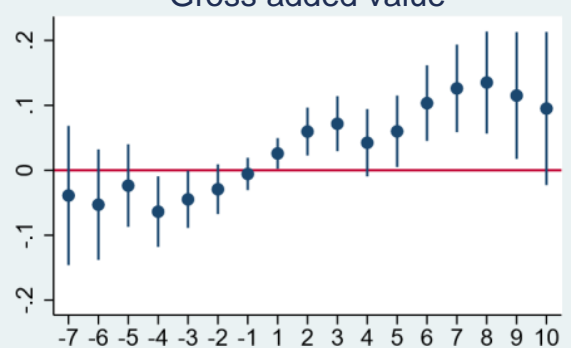

Sales

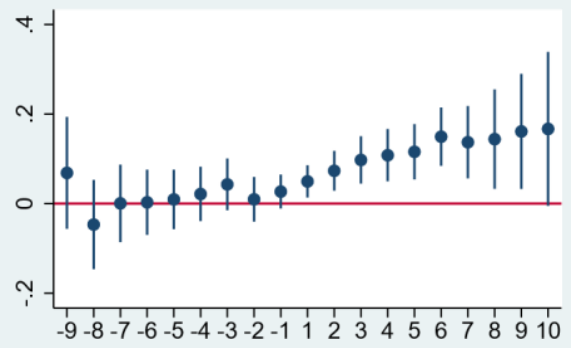

Gross added value

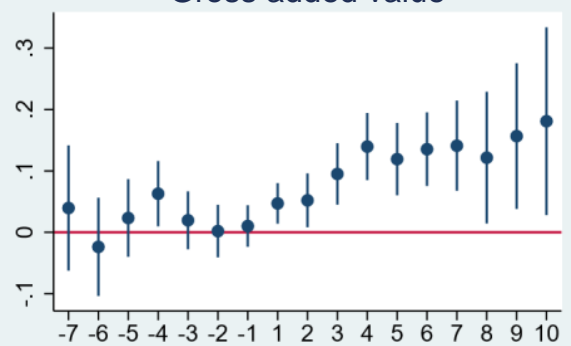

Number of employees

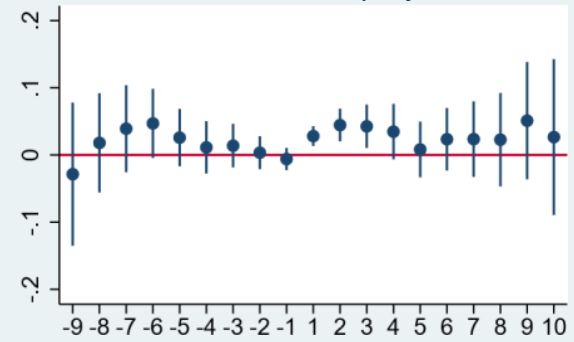

Non-salary staff expenditure

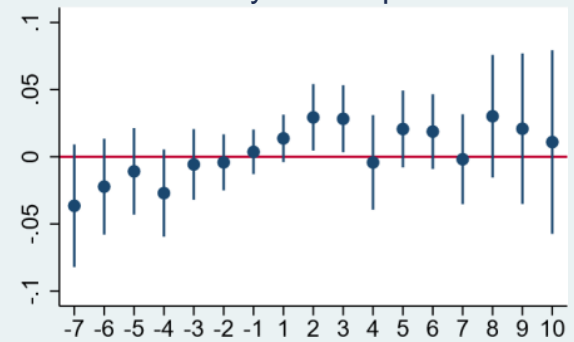

Number of employees

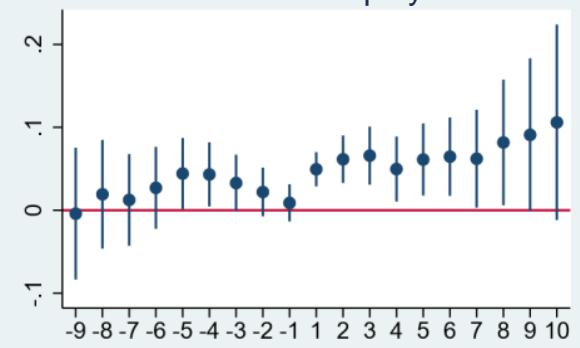

Non-salary staff expenditure

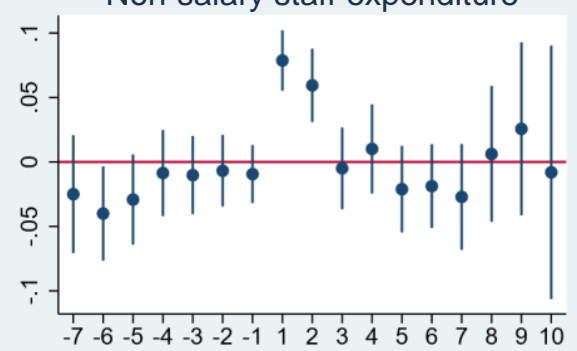

Note: Analysis conducted separately for large and small firms. See notes to Figure A.6. 
Figure A.23. DID effects - Heterogeneity: High scoring threshold (top) and low scoring threshold (bottom) firms only
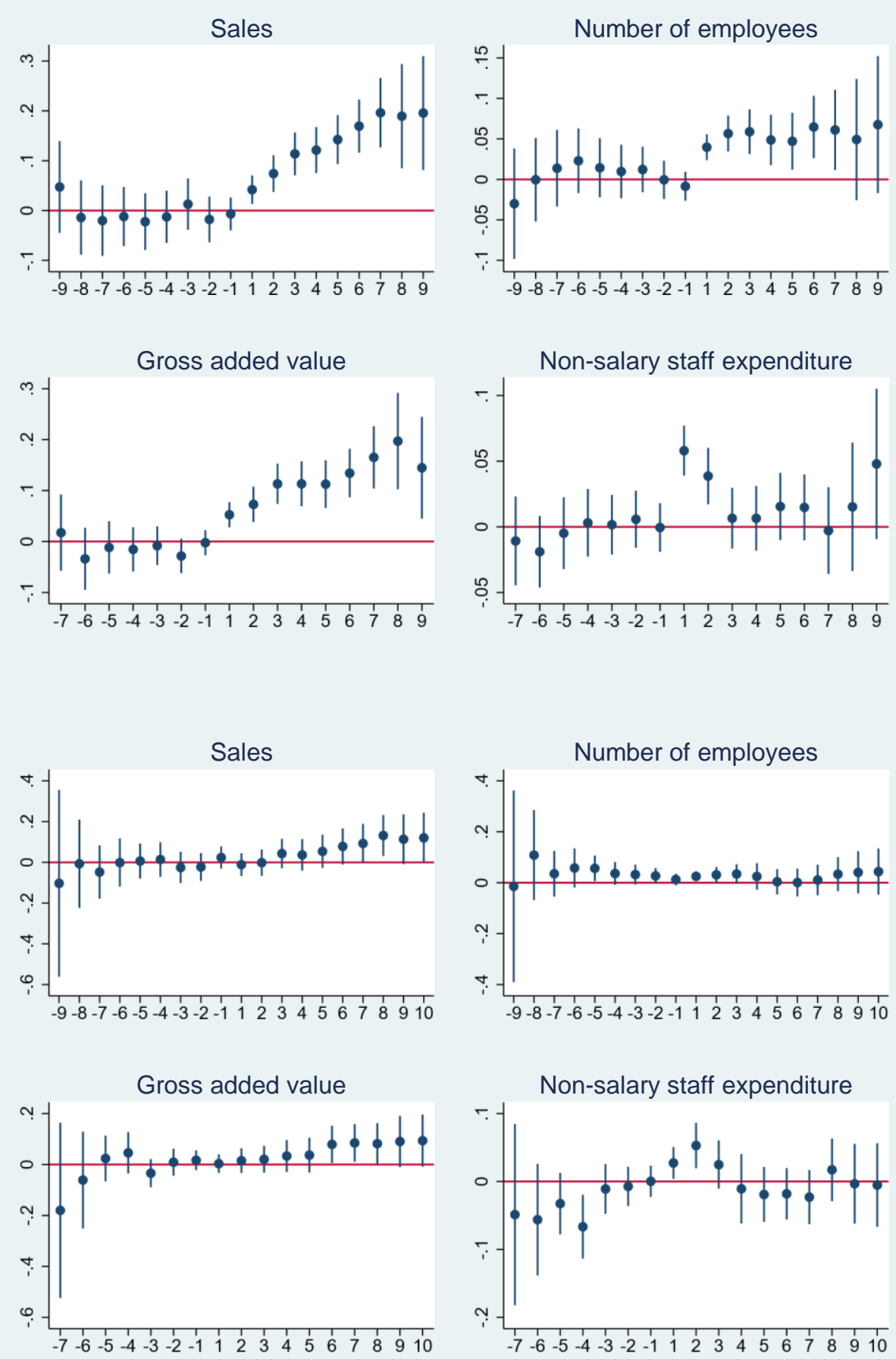

Note: Analysis conducted separately for firms that applied to calls that were then subject to either high (55 or higher) or low scoring thresholds (52.5 or lower). See notes to Figure A.6. 
Figure A.24. DID effects - Heterogeneity: Exporters (top) and non-exporters (bottom) firms only
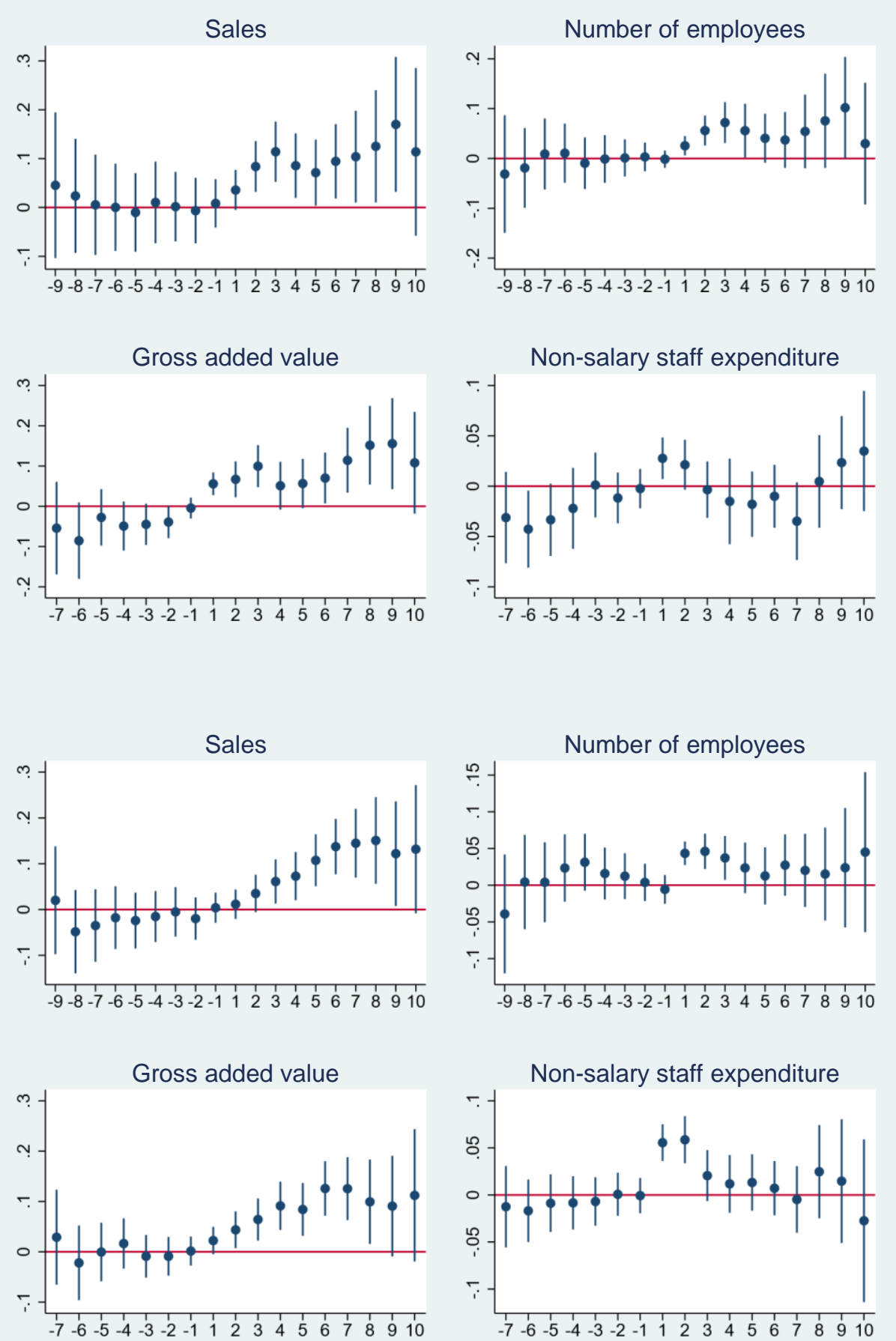

Note: Analysis conducted separately for firms that exported or not at the time when they apply. See notes to Figure A.6. 
Figure A.25. DID effects - Heterogeneity: High-schooling (top) and low-schooling firms only
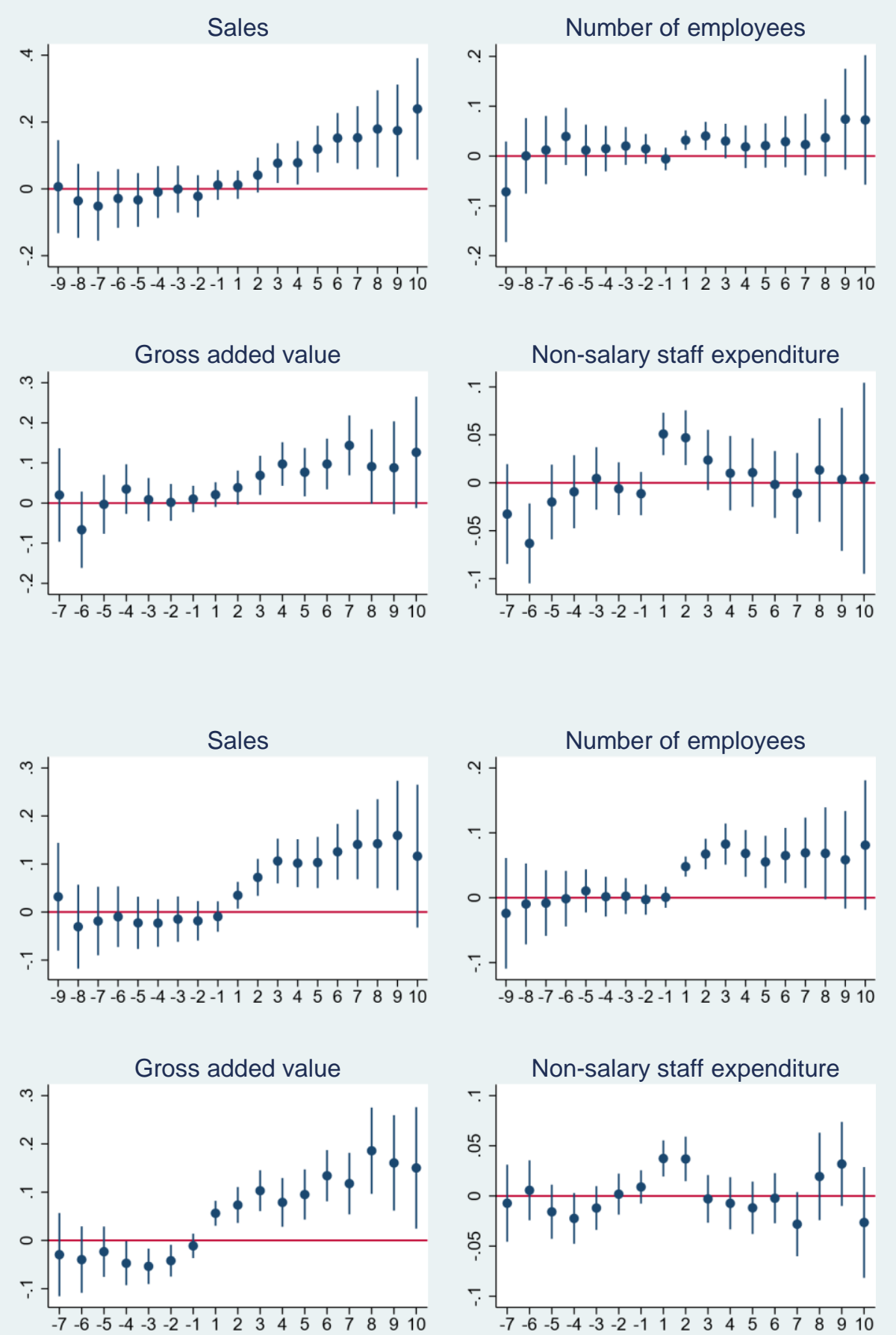

Note: Analysis conducted separately for firms with high- or low-schooling workforces (at the time when they apply). Number of observations: 65,539 and 67,646, respectively. See notes to Figure A.6. 
Figure A.26. DID effects - Heterogeneity: Older workforce (top) and younger workforce (bottom) firms only
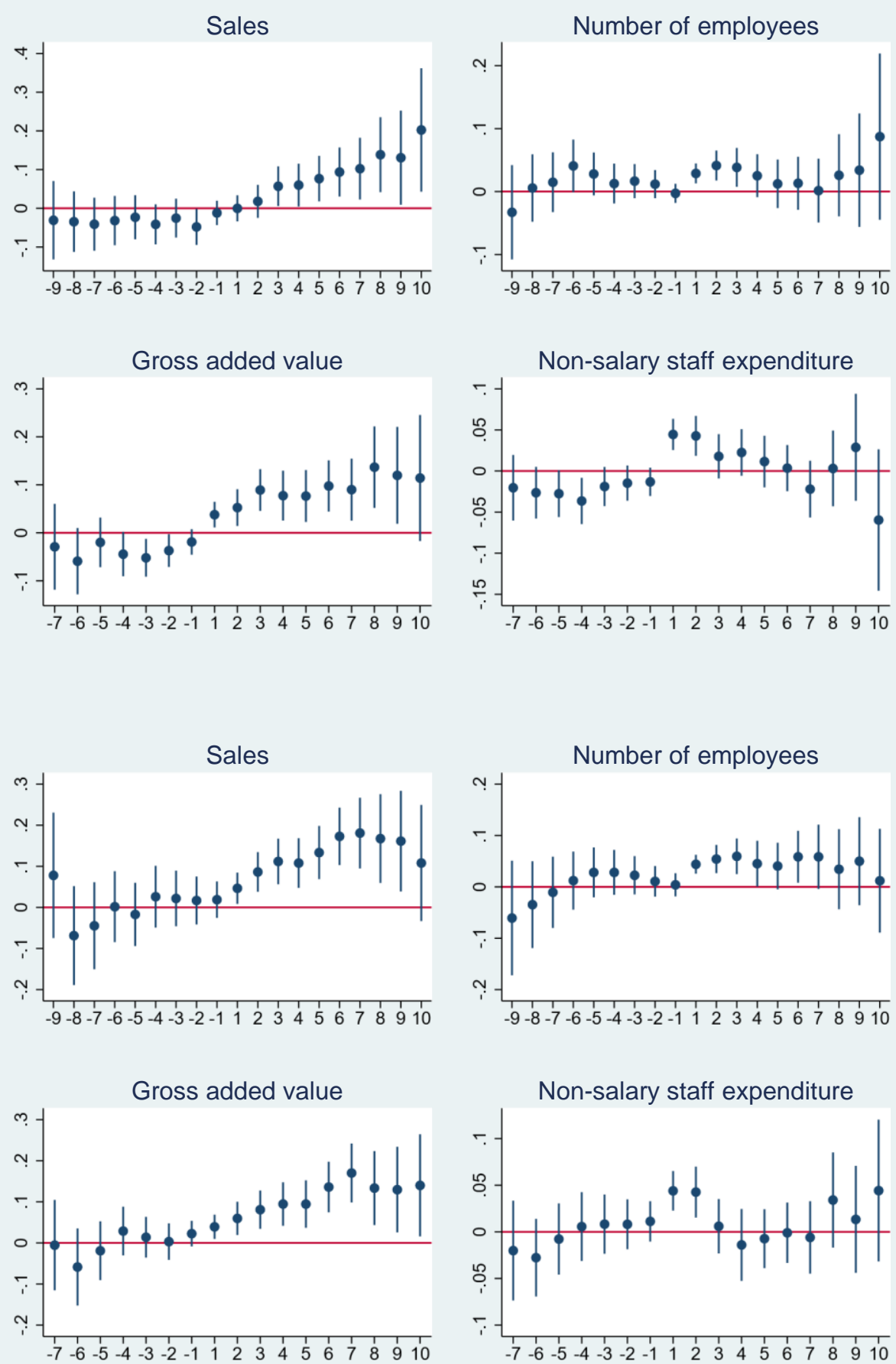

Note: Analysis conducted separately for firms with older or younger workforces (at the time when they apply). See notes to Figure A.6. 
Figure A.27. DID effects - Heterogeneity: High female share (top) and low female share (bottom) firms only
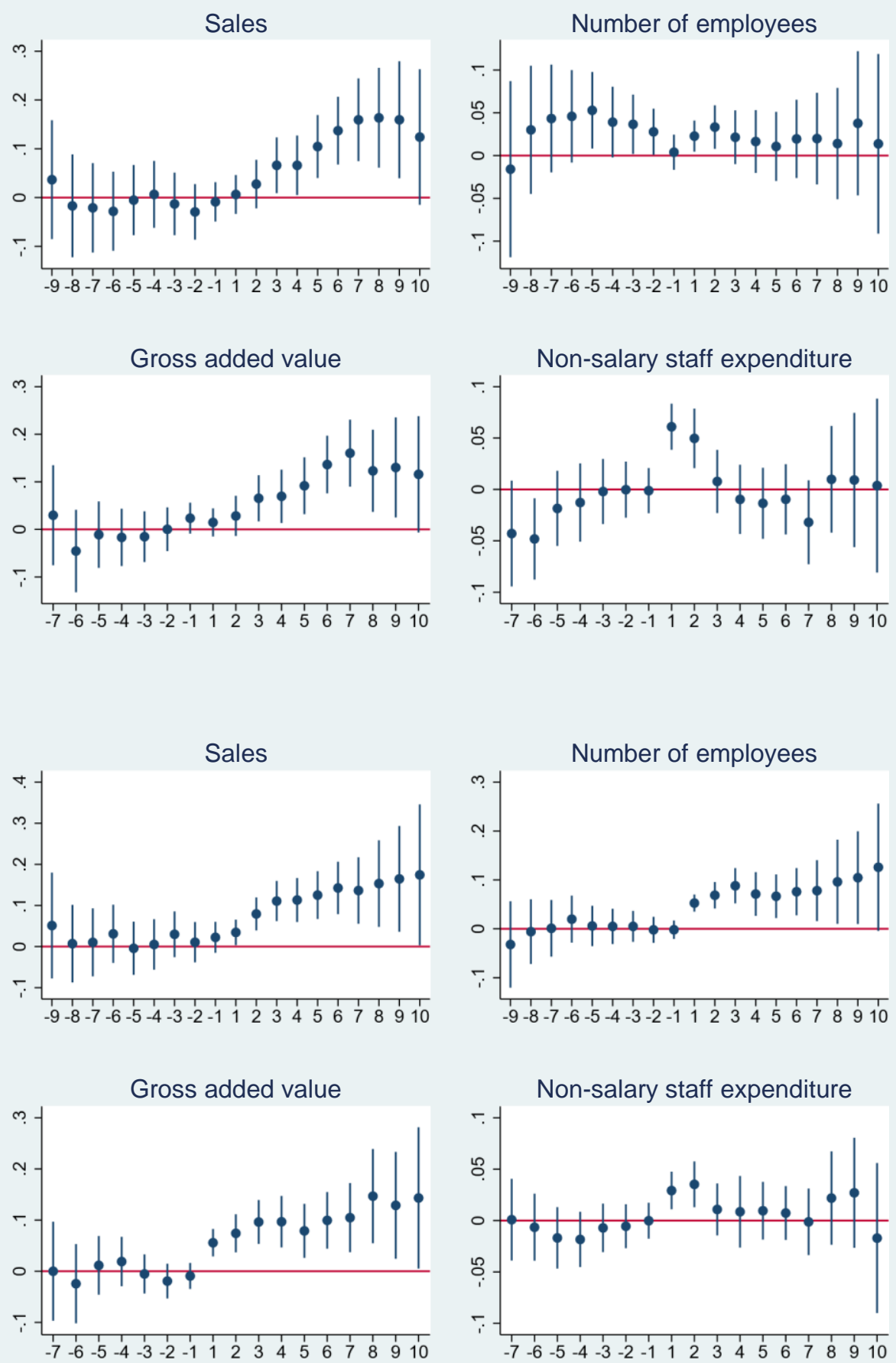

Note: Analysis conducted separately for firms with high- or low-female workforces (at the time when they apply). See notes to Figure A.6. 
Table A.1. Funding thresholds (marks out of 100), years, applicants and amounts

\begin{tabular}{|c|c|c|c|c|c|c|}
\hline & & \multicolumn{2}{|l|}{ Regions } & \multirow[t]{2}{*}{$\begin{array}{c}\text { Funding } \\
\text { starts }\end{array}$} & \multirow[t]{2}{*}{$\begin{array}{l}\text { Number of } \\
\text { Applicants }\end{array}$} & \multirow[t]{2}{*}{$\begin{array}{l}\text { Public } \\
\text { Funding }\end{array}$} \\
\hline & North \& Centr & & & & & \\
\hline Call & \& Alentejo & Algarve & Lisbon & & & \\
\hline 2007 & 50 & 50 & 50 & 2008 & 1,788 & 22.9 \\
\hline 2008 & 60 & 50 & 60 & 2009 & 2,203 & 39.0 \\
\hline 2009 & 62.5 & 52.5 & 55 & 2010 & 1,736 & 36.7 \\
\hline 2010 & 65 & 60 & 50 & 2011 & 2,812 & 38.7 \\
\hline 2011 & 52.5 & 50 & 50 & 2012 & 3,852 & 34.8 \\
\hline
\end{tabular}

Note: The first three columns indicate the threshold applicable in each call in each region (a 'quality' minimum of 50 or higher if demand exceeded the budget available). Funding to accepted applications began in the year following that of the call, as indicated in the fourth column. Columns five and six indicate the number of firms that applied to each call and the amount of public funding (European Social Fund and national funds) disbursed in each call. 
Table A.2. Descriptive statistics, application year, 2010 call only

\begin{tabular}{|c|c|c|c|c|c|c|}
\hline & \multicolumn{2}{|c|}{ (1) } & \multicolumn{2}{|c|}{$(2)$} & \multicolumn{2}{|c|}{ (3) } \\
\hline & \multicolumn{2}{|c|}{ Approved } & \multicolumn{2}{|c|}{ Rejected } & \multicolumn{2}{|c|}{ Difference } \\
\hline & Mean & SD & Mean & SD & b & $\mathrm{t}$ \\
\hline Total sales & 10.05 & 42.96 & 23.95 & 336.93 & 13.90 & $(1.56)$ \\
\hline Number of employees & 65.13 & 176.46 & 89.68 & 485.58 & 24.55 & $(1.74)$ \\
\hline Capital equity & 1.87 & 14.23 & 1.88 & 21.28 & 0.02 & $(0.02)$ \\
\hline Firm age & 19.79 & 14.49 & 20.25 & 33.83 & 0.46 & $(0.45)$ \\
\hline Gross added value & 2.37 & 8.74 & 3.56 & 24.75 & 1.19 & $(1.58)$ \\
\hline Investment & 0.24 & 4.16 & 1.91 & 33.66 & 1.67 & $(1.78)$ \\
\hline Profits & 0.27 & 4.36 & 0.64 & 8.72 & 0.38 & $(1.31)$ \\
\hline Non-salary staff expenditure & 0.34 & 1.24 & 0.47 & 3.12 & 0.13 & $(1.33)$ \\
\hline Training expenditure & 6.02 & 39.36 & 3.80 & 24.95 & -2.22 & $(-1.41)$ \\
\hline North region & 0.39 & & 0.42 & & 0.02 & $(1.04)$ \\
\hline Centre region & 0.34 & & 0.40 & & $0.07^{\star *}$ & (3.21) \\
\hline Employees' female share & 0.34 & 0.26 & 0.43 & 0.32 & $0.09^{* * *}$ & $(7.24)$ \\
\hline Employees' age & 38.84 & 4.71 & 38.29 & 4.99 & $-0.55^{\star \star}$ & $(-2.60)$ \\
\hline Employees' tenure & 7.32 & 4.77 & 6.60 & 4.74 & $-0.72^{\star \star \star}$ & $(-3.43)$ \\
\hline Employees' schooling & 9.08 & 2.20 & 9.60 & 2.69 & $0.52^{* \star *}$ & $(4.97)$ \\
\hline Employees' total wage & 949.84 & 647.32 & 885.42 & 436.92 & $-64.42^{*}$ & $(-2.50)$ \\
\hline Training funding requested & 101.47 & 127.86 & 87.66 & 153.23 & $-13.81^{*}$ & $(-2.28)$ \\
\hline Training funding approved & 36.55 & 30.46 & 1.83 & 9.99 & $-34.71^{* * *}$ & $(-31.00)$ \\
\hline Workers to train request & 120.70 & 125.97 & 135.74 & 206.79 & $15.04^{*}$ & $(2.15)$ \\
\hline Workers to train approved & 109.30 & 99.12 & 0.00 & 0.00 & $-109.30^{\star \star *}$ & $(-30.84)$ \\
\hline Training hours request & 3720.15 & 4055.64 & 4165.69 & 5559.63 & $445.54^{*}$ & $(2.18)$ \\
\hline Training hours approved & 3359.16 & 3124.01 & 0.00 & 0.00 & $-3359.16^{\star \star \star}$ & $(-30.07)$ \\
\hline Duration of training (months) & 13.45 & 6.59 & 10.56 & 4.86 & $-2.89^{* \star \star}$ & $(-10.81)$ \\
\hline Training hours & 1019.40 & 3164.10 & 1937.47 & 17416.74 & $918.07^{*}$ & $(1.97)$ \\
\hline Non-catalogue training & 336.07 & 1883.36 & 1292.47 & 16863.50 & $956.40^{*}$ & $(2.16)$ \\
\hline Externals-provided training & 661.08 & 2386.87 & 933.39 & 5350.56 & 272.32 & $(1.67)$ \\
\hline Working-time training & 837.90 & 2963.10 & 1691.90 & 17026.29 & 854.00 & $(1.88)$ \\
\hline Workers under training & 48.26 & 130.12 & 75.95 & 620.28 & 27.69 & $(1.65)$ \\
\hline Observations & 782 & & 1484 & & 2266 & \\
\hline
\end{tabular}

Note: All statistics refer to 2010, the year before the funding starts in the 2010 call considered here. See the footnotes to Table 1 and Table 2 for more information on the variables. 
Table A.3. Descriptive statistics, full sample

\begin{tabular}{|c|c|c|c|c|c|c|}
\hline & \multicolumn{2}{|c|}{$(1)$} & \multicolumn{2}{|c|}{ (2) } & \multicolumn{2}{|c|}{ (3) } \\
\hline & \multicolumn{2}{|c|}{ Approved } & \multicolumn{2}{|c|}{ Rejected } & \multicolumn{2}{|c|}{ Difference } \\
\hline & Mean & SD & Mean & SD & $\mathrm{b}$ & $\mathrm{t}$ \\
\hline Total sales & 19.55 & 139.00 & 14.06 & 170.03 & $-5.49^{\star \star \star}$ & $(-6.43)$ \\
\hline Number of employees & 111.77 & 493.81 & 111.16 & 644.90 & -0.61 & $(-0.19)$ \\
\hline Capital equity & 4.25 & 52.01 & 4.01 & 75.29 & -0.24 & $(-0.69)$ \\
\hline Domestic private share & 88.84 & 30.56 & 81.19 & 38.48 & $-7.65^{\star \star *}$ & $(-40.17)$ \\
\hline Foreign share & 7.26 & 24.97 & 5.20 & 21.51 & $-2.06^{\star \star \star}$ & $(-15.50)$ \\
\hline Firm age & 23.50 & 46.94 & 23.85 & 59.53 & 0.34 & $(1.17)$ \\
\hline Gross added value & 5.19 & 40.82 & 3.34 & 20.21 & $-1.85^{\star \star \star}$ & $(-8.83)$ \\
\hline Total sales (2) & 20.17 & 124.67 & 15.80 & 181.34 & $-4.37^{\star \star \star}$ & $(-4.66)$ \\
\hline Investment & 1.17 & 15.47 & 0.62 & 11.94 & $-0.55^{\star \star \star}$ & $(-6.31)$ \\
\hline Profits & 0.91 & 34.71 & 0.40 & 11.67 & $-0.51^{\star *}$ & $(-3.02)$ \\
\hline Income taxes paid & 0.27 & 4.08 & 0.14 & 2.06 & $-0.13^{\star \star \star}$ & $(-6.29)$ \\
\hline Non-salary staff expenditure & 0.64 & 3.94 & 0.49 & 2.46 & $-0.16^{\star \star \star}$ & $(-7.43)$ \\
\hline Food & 0.05 & & 0.03 & & $-0.02^{\star \star \star}$ & $(-16.47)$ \\
\hline Clothing & 0.04 & & 0.02 & & $-0.01^{* * *}$ & $(-14.34)$ \\
\hline Ceramics & 0.04 & & 0.02 & & $-0.02^{* \star *}$ & $(-23.04)$ \\
\hline Molds & 0.07 & & 0.04 & & $-0.03^{\star \star \star}$ & $(-21.69)$ \\
\hline Construction & 0.04 & & 0.04 & & $0.00^{* *}$ & $(2.81)$ \\
\hline Electric appliances & 0.04 & & 0.04 & & -0.00 & $(-1.63)$ \\
\hline Wholesale & 0.11 & & 0.09 & & $-0.02^{* * *}$ & $(-13.33)$ \\
\hline Retail & 0.05 & & 0.07 & & $0.02^{* * *}$ & $(11.39)$ \\
\hline Transport & 0.03 & & 0.03 & & $-0.01^{\star \star \star}$ & $(-7.26)$ \\
\hline North region & 0.47 & & 0.42 & & $-0.05^{\star \star \star}$ & $(-19.01)$ \\
\hline Centre region & 0.33 & & 0.35 & & $0.02^{\star \star \star}$ & $(7.78)$ \\
\hline Lisbon region & 0.13 & & 0.16 & & $0.03^{* * *}$ & $(16.03)$ \\
\hline Exports & 10.82 & 66.86 & 9.09 & 109.32 & -1.74 & $(-1.92)$ \\
\hline N. of products exported & 25.97 & 57.27 & 23.56 & 64.59 & $-2.41^{\star \star \star}$ & $(-4.00)$ \\
\hline N. of countries exported to & 8.89 & 11.62 & 6.80 & 9.96 & $-2.09^{* * *}$ & $(-19.81)$ \\
\hline Employees' female share & 0.36 & 0.28 & 0.44 & 0.32 & $0.09^{* * *}$ & (52.52) \\
\hline Employees' age & 38.77 & 5.19 & 38.55 & 5.56 & $-0.22^{\star \star \star}$ & $(-7.34)$ \\
\hline Employees' tenure & 9.47 & 34.74 & 9.10 & 41.20 & -0.37 & $(-1.75)$ \\
\hline Employees' open-ended contract & 0.69 & 0.25 & 0.67 & 0.28 & $-0.02^{* * *}$ & $(-13.71)$ \\
\hline Employees' schooling & 9.08 & 2.37 & 9.71 & 2.85 & $0.63^{\star \star *}$ & $(43.50)$ \\
\hline Employees' base wage & 792.81 & 389.15 & 796.41 & 794.20 & 3.61 & $(1.10)$ \\
\hline Employees' total wage & 930.33 & 450.06 & 919.80 & 826.42 & $-10.53^{* *}$ & $(-3.00)$ \\
\hline Observations & 51958 & & 81093 & & 133051 & \\
\hline
\end{tabular}

Note: Full data set, covering all firms observed in all years (2002-2017). See the footnotes to Table 1 and Table 2 for more information on the variables. 
Table A.4. Regression results (1/2)

\begin{tabular}{|c|c|c|c|c|}
\hline & (1) & $(2)$ & (3) & (4) \\
\hline & Log sales & $\begin{array}{c}\text { Log } \\
\text { employees }\end{array}$ & $\begin{array}{c}\text { Log gross } \\
\text { added value }\end{array}$ & $\begin{array}{l}\text { Log non-salary } \\
\text { staff expenditure }\end{array}$ \\
\hline Year $-9^{*}$ Aprov & $\begin{array}{l}.031 \\
(.045)\end{array}$ & $\begin{array}{l}-.031 \\
(.034)\end{array}$ & & \\
\hline Year $-8^{*}$ Aprov & $\begin{array}{l}-.021 \\
(.036)\end{array}$ & $\begin{array}{l}.007 \\
(.025)\end{array}$ & & \\
\hline Year $-7^{*}$ Aprov & $\begin{array}{l}-.020 \\
(.031)\end{array}$ & $\begin{array}{l}.016 \\
(.022)\end{array}$ & $\begin{array}{l}.002 \\
(.037)\end{array}$ & $\begin{array}{l}-.019 \\
(.016)\end{array}$ \\
\hline Year $-6^{*}$ Aprov & $\begin{array}{l}-.009 \\
(.027)\end{array}$ & $\begin{array}{c}.032 \\
(.018)^{*}\end{array}$ & $\begin{array}{l}-.042 \\
(.029)\end{array}$ & $\begin{array}{l}-.025 \\
(.013)^{*}\end{array}$ \\
\hline Year $-5^{*}$ Aprov & $\begin{array}{r}-.013 \\
(.024)\end{array}$ & $\begin{array}{l}.030 \\
(.015)^{*}\end{array}$ & $\begin{array}{l}-.003 \\
(.023)\end{array}$ & $\begin{array}{l}-.017 \\
(.012)\end{array}$ \\
\hline Year $-4^{*}$ Aprov & $\begin{array}{l}-.002 \\
(.023)\end{array}$ & $\begin{array}{l}.023 \\
(.014)\end{array}$ & $\begin{array}{r}-.001 \\
(.019)\end{array}$ & $\begin{array}{l}-.015 \\
(.012)\end{array}$ \\
\hline Year $-3^{*}$ Aprov & $\begin{array}{l}.002 \\
(.021)\end{array}$ & $\begin{array}{l}.021 \\
(.012)^{*}\end{array}$ & $\begin{array}{l}-.013 \\
(.016)\end{array}$ & $\begin{array}{l}-.004 \\
(.010)\end{array}$ \\
\hline Year $-2^{*}$ Aprov & $\begin{array}{r}-.012 \\
(.019)\end{array}$ & $\begin{array}{l}.012 \\
(.010)\end{array}$ & $\begin{array}{l}-.012 \\
(.014)\end{array}$ & $\begin{array}{l}-.003 \\
(.009)\end{array}$ \\
\hline Year $-1^{*}$ Aprov & $\begin{array}{l}.005 \\
(.014)\end{array}$ & $\begin{array}{l}.001 \\
(.007)\end{array}$ & $\begin{array}{l}.004 \\
(.010)\end{array}$ & $\begin{array}{l}-.0009 \\
(.007)\end{array}$ \\
\hline Year $+1^{*}$ Aprov & $\begin{array}{l}.021 \\
(.013)\end{array}$ & $\begin{array}{c}.035 \\
(.006)^{\cdots *}\end{array}$ & $\begin{array}{c}.035 \\
(.010)^{* *}\end{array}$ & $\begin{array}{c}.044 \\
(.007)^{* *}\end{array}$ \\
\hline Year $+2^{*}$ Aprov & $\begin{array}{l}.049 \\
(.016)^{\cdots *}\end{array}$ & $\begin{array}{l}.046 \\
(.009)^{\cdots}\end{array}$ & $\begin{array}{l}.051 \\
(.014)^{* *}\end{array}$ & $\begin{array}{l}.042 \\
(.009)^{* *}\end{array}$ \\
\hline Year $+3^{*}$ Aprov & $\begin{array}{c}.080 \\
(.019)^{* \cdots}\end{array}$ & $\begin{array}{c}.047 \\
(.012)^{* *}\end{array}$ & $\begin{array}{c}.079 \\
(.016)^{* \cdots}\end{array}$ & $\begin{array}{l}.010 \\
(.010)\end{array}$ \\
\hline Year $+4^{*}$ Aprov & $\begin{array}{c}.079 \\
(.021)^{* *}\end{array}$ & $\begin{array}{l}.033 \\
(.014)^{* *}\end{array}$ & $\begin{array}{c}.080 \\
(.019)^{\cdots} \cdots\end{array}$ & $\begin{array}{l}.002 \\
(.012)\end{array}$ \\
\hline Year $+5^{*}$ Aprov & $\begin{array}{l}.101 \\
(.022)^{\cdots}\end{array}$ & $\begin{array}{l}.025 \\
(.015)^{*}\end{array}$ & $\begin{array}{c}.079 \\
(.020)^{\cdots}\end{array}$ & $\begin{array}{l}.0003 \\
(.011)\end{array}$ \\
\hline Year $+6^{*}$ Aprov & $\begin{array}{l}.130 \\
(.024)^{* \cdots}\end{array}$ & $\begin{array}{l}.035 \\
(.017)^{* *}\end{array}$ & $\begin{array}{l}.111 \\
(.021)^{* *}\end{array}$ & $\begin{array}{l}-.0002 \\
(.011)\end{array}$ \\
\hline Year $+7^{*}$ Aprov & $\begin{array}{l}.140 \\
(.030)^{\cdots} \cdots\end{array}$ & $\begin{array}{l}.032 \\
(.021)\end{array}$ & $\begin{array}{l}.125 \\
(.025)^{* *}\end{array}$ & $\begin{array}{l}-.015 \\
(.013)\end{array}$ \\
\hline Year $+8^{*}$ Aprov & $\begin{array}{l}.154 \\
(.037)^{\cdots \cdots}\end{array}$ & $\begin{array}{l}.034 \\
(.026)\end{array}$ & $\begin{array}{l}.127 \\
(.032)^{\cdots}\end{array}$ & $\begin{array}{l}.019 \\
(.018)\end{array}$ \\
\hline Year $+9^{*}$ Aprov & $\begin{array}{c}.153 \\
(.045)^{\cdots}\end{array}$ & $\begin{array}{l}.052 \\
(.032)\end{array}$ & $\begin{array}{c}.121 \\
(.038)^{* *}\end{array}$ & $\begin{array}{l}.020 \\
(.022)\end{array}$ \\
\hline Year $+10^{*}$ Aprov & $\begin{array}{l}.144 \\
(.055)^{\cdots *}\end{array}$ & $\begin{array}{l}.047 \\
(.042)\end{array}$ & $\begin{array}{l}.119 \\
(.047)^{* *}\end{array}$ & $\begin{array}{l}.0009 \\
(.029)\end{array}$ \\
\hline Const. & $\begin{array}{c}.781 \\
(.012)^{\cdots}\end{array}$ & $\begin{array}{c}3.503 \\
(.008)^{\cdots}\end{array}$ & $\begin{array}{c}-.185 \\
(.008)^{\cdots}\end{array}$ & $\begin{array}{l}-5.621 \\
(.005)^{\cdots}\end{array}$ \\
\hline $\begin{array}{l}\text { Obs. } \\
R^{2}\end{array}$ & $\begin{array}{c}125868 \\
.888\end{array}$ & $\begin{array}{c}133185 \\
.898\end{array}$ & $\begin{array}{c}103723 \\
.9\end{array}$ & $\begin{array}{c}106470 \\
.713\end{array}$ \\
\hline
\end{tabular}

Note: See notes to Figure 1. 
66

Table A.5. Regression results (2/2)

\begin{tabular}{|c|c|c|c|c|}
\hline & $(1)$ & $(2)$ & (3) & $(4)$ \\
\hline & $\begin{array}{l}\text { Export } \\
\text { status }\end{array}$ & Log profits & $\begin{array}{c}\text { Log sales } \\
\text { per worker }\end{array}$ & $\begin{array}{c}\text { Log } \\
\text { investment }\end{array}$ \\
\hline Year $-9^{*}$ Aprov & $\begin{array}{c}-.083 \\
(.018)^{\cdots}\end{array}$ & & $\begin{array}{c}.062 \\
(.036)^{*}\end{array}$ & \\
\hline Year $-8^{*}$ Aprov & $\begin{array}{c}-.045 \\
(.013)^{\cdots}\end{array}$ & & $\begin{array}{l}-.029 \\
(.027)\end{array}$ & \\
\hline Year $-7^{*}$ Aprov & $\begin{array}{c}-.033 \\
(.011)^{\cdots *}\end{array}$ & $\begin{array}{l}-.183 \\
(.079)^{* *}\end{array}$ & $\begin{array}{l}-.033 \\
(.024)\end{array}$ & $\begin{array}{c}-.350 \\
(.085) \cdots\end{array}$ \\
\hline Year $-6^{*}$ Aprov & $\begin{array}{c}-.032 \\
(.010)^{* *}\end{array}$ & $\begin{array}{c}-.178 \\
(.062)^{* *}\end{array}$ & $\begin{array}{l}-.033 \\
(.022)\end{array}$ & $\begin{array}{c}-.239 \\
(.068)^{\cdots *}\end{array}$ \\
\hline Year $-5^{*}$ Aprov & $\begin{array}{c}-.030 \\
(.009)^{*}\end{array}$ & $\begin{array}{c}-.183 \\
(.053)^{* *}\end{array}$ & $\begin{array}{l}-.035 \\
(.020)^{*}\end{array}$ & $\begin{array}{l}-.162 \\
(.059)^{\cdots}\end{array}$ \\
\hline Year $-4^{*}$ Aprov & $\begin{array}{l}-.019 \\
(.008)^{* *}\end{array}$ & $\begin{array}{l}-.109 \\
(.048)^{* *}\end{array}$ & $\begin{array}{l}-.023 \\
(.020)\end{array}$ & $\begin{array}{l}-.152 \\
(.054)^{\cdots *}\end{array}$ \\
\hline Year $-3^{*}$ Aprov & $\begin{array}{l}-.019 \\
(.008)^{* *}\end{array}$ & $\begin{array}{l}-.095 \\
(.043)^{* *}\end{array}$ & $\begin{array}{l}-.006 \\
(.019)\end{array}$ & $\begin{array}{l}-.068 \\
(.049)\end{array}$ \\
\hline Year $-2 *$ Aprov & $\begin{array}{l}-.019 \\
(.007)^{* *}\end{array}$ & $\begin{array}{l}-.071 \\
(.041)^{*}\end{array}$ & $\begin{array}{l}-.023 \\
(.018)\end{array}$ & $\begin{array}{c}-.123 \\
(.047)^{\cdots}\end{array}$ \\
\hline Year $-1^{*}$ Aprov & $\begin{array}{l}-.007 \\
(.006)\end{array}$ & $\begin{array}{l}-.073 \\
(.033)^{* *}\end{array}$ & $\begin{array}{l}.003 \\
(.014)\end{array}$ & $\begin{array}{l}-.059 \\
(.041)\end{array}$ \\
\hline Year $+1^{*}$ Aprov & $\begin{array}{c}-.00003 \\
(.006)\end{array}$ & $\begin{array}{r}-.008 \\
(.035)\end{array}$ & $\begin{array}{r}-.016 \\
(.013)\end{array}$ & $\begin{array}{c}.071 \\
(.043)^{*}\end{array}$ \\
\hline Year $+2^{*}$ Aprov & $\begin{array}{l}.004 \\
(.007)\end{array}$ & $\begin{array}{l}.040 \\
(.042)\end{array}$ & $\begin{array}{c}-.0002 \\
(.015)\end{array}$ & $\begin{array}{l}.085 \\
(.049)^{*}\end{array}$ \\
\hline Year $+3^{*}$ Aprov & $\begin{array}{l}.018 \\
(.008)^{* *}\end{array}$ & $\begin{array}{l}.078 \\
(.045)^{*}\end{array}$ & $\begin{array}{l}.033 \\
(.017)^{*}\end{array}$ & $\begin{array}{l}.009 \\
(.052)\end{array}$ \\
\hline Year $+4^{*}$ Aprov & $\begin{array}{c}.023 \\
(.009)^{\cdots}\end{array}$ & $\begin{array}{l}.087 \\
(.049)^{*}\end{array}$ & $\begin{array}{c}.046 \\
(.018)^{* *}\end{array}$ & $\begin{array}{l}.043 \\
(.055)\end{array}$ \\
\hline Year $+5^{*}$ Aprov & $\begin{array}{l}.018 \\
(.009)^{* *}\end{array}$ & $\begin{array}{c}.160 \\
(.050)^{*}\end{array}$ & $\begin{array}{c}.066 \\
(.018)^{* *}\end{array}$ & $\begin{array}{l}.137 \\
(.057)^{* *}\end{array}$ \\
\hline Year $+6^{*}$ Aprov & $\begin{array}{l}.016 \\
(.009)^{*}\end{array}$ & $\begin{array}{l}.177 \\
(.051) * *\end{array}$ & $\begin{array}{c}.086 \\
(.019)^{* * *}\end{array}$ & $\begin{array}{c}.163 \\
(.057)^{\cdots *}\end{array}$ \\
\hline Year $+7^{*}$ Aprov & $\begin{array}{l}.002 \\
(.010)\end{array}$ & $\begin{array}{c}.231 \\
(.059)^{* \cdots}\end{array}$ & $\begin{array}{c}.095 \\
(.024)^{* \cdots}\end{array}$ & $\begin{array}{l}.135 \\
(.066)^{* *}\end{array}$ \\
\hline Year $+8^{*}$ Aprov & $\begin{array}{l}.017 \\
(.013)\end{array}$ & $\begin{array}{c}.267 \\
(.069)^{*}\end{array}$ & $\begin{array}{c}.099 \\
(.029)^{* *}\end{array}$ & $\begin{array}{c}.218 \\
(.078)^{\cdots} \cdots\end{array}$ \\
\hline Year $+9^{*}$ Aprov & $\begin{array}{l}.010 \\
(.014)\end{array}$ & $\begin{array}{c}.254 \\
(.078) \cdots\end{array}$ & $\begin{array}{l}.080 \\
(.037)^{* *}\end{array}$ & $\begin{array}{l}.176 \\
(.089)^{* *}\end{array}$ \\
\hline Year $+10^{*}$ Aprov & $\begin{array}{l}-.004 \\
(.018)\end{array}$ & $\begin{array}{c}.434 \\
(.102)^{*}\end{array}$ & $\begin{array}{l}.086 \\
(.047)^{*}\end{array}$ & $\begin{array}{c}.376 \\
(.111)^{\cdots} \cdots\end{array}$ \\
\hline Const. & $\begin{array}{c}.322 \\
(.004)^{* *}\end{array}$ & $\begin{array}{l}-2.943 \\
(.020)^{\cdots *}\end{array}$ & $\begin{array}{l}-2.729 \\
(.009)^{* \cdots}\end{array}$ & $\begin{array}{l}-2.588 \\
(.021)^{\cdots}\end{array}$ \\
\hline $\begin{array}{l}\text { Obs. } \\
R^{2} \\
\end{array}$ & $\begin{array}{c}133221 \\
.728 \\
\end{array}$ & $\begin{array}{c}84424 \\
.755 \\
\end{array}$ & $\begin{array}{c}125838 \\
.808 \\
\end{array}$ & $\begin{array}{c}87984 \\
.644 \\
\end{array}$ \\
\hline
\end{tabular}

Note: See notes to Figure 1. 
Table A.6. Multiple testing analysis $1 / 2$

\begin{tabular}{lccccccc}
\hline Outcome & Family & Coef & Std Err & p-value & pwyoung & pbonf & psidak \\
\hline Log sales & 1 & 0.021 & 0.013 & 0.107 & 0.933 & 1.000 & 0.895 \\
Log employment & 1 & 0.035 & 0.006 & 0.000 & 0.133 & 0.000 & 0.000 \\
Log sales per worker & 1 & -0.016 & 0.013 & 0.221 & 1.000 & 1.000 & 0.982 \\
Export status & 1 & 0.000 & 0.006 & 0.996 & 1.000 & 1.000 & 1.000 \\
Log exports & 1 & 0.139 & 0.063 & 0.027 & 0.733 & 0.825 & 0.567 \\
Log profits & 1 & -0.008 & 0.035 & 0.809 & 1.000 & 1.000 & 1.000 \\
Profit ratio & 1 & 0.004 & 0.035 & 0.913 & 1.000 & 1.000 & 1.000 \\
Log taxes & 1 & -0.018 & 0.034 & 0.595 & 1.000 & 1.000 & 1.000 \\
Log non wage staff expenditure & 1 & 0.084 & 0.008 & 0.000 & 0.000 & 0.000 & 0.000 \\
Log investment & 1 & 0.070 & 0.043 & 0.101 & 0.933 & 1.000 & 0.895 \\
Log sales (2nd measure) & 1 & 0.036 & 0.009 & 0.000 & 0.267 & 0.003 & 0.003 \\
Log added value per worker & 1 & 0.003 & 0.010 & 0.773 & 1.000 & 1.000 & 1.000 \\
Log sales & 2 & 0.049 & 0.016 & 0.003 & 0.400 & 0.103 & 0.098 \\
Log employment & 2 & 0.046 & 0.009 & 0.000 & 0.200 & 0.000 & 0.000 \\
Log sales per worker & 2 & 0.000 & 0.015 & 0.990 & 1.000 & 1.000 & 1.000 \\
Export status & 2 & 0.004 & 0.007 & 0.593 & 1.000 & 1.000 & 1.000 \\
Log exports & 2 & 0.129 & 0.078 & 0.097 & 0.933 & 1.000 & 0.895 \\
Log profits & 2 & 0.040 & 0.042 & 0.340 & 1.000 & 1.000 & 0.998 \\
Profit ratio & 2 & -0.037 & 0.073 & 0.618 & 1.000 & 1.000 & 1.000 \\
Log taxes & 2 & -0.049 & 0.038 & 0.203 & 1.000 & 1.000 & 0.979 \\
Log non wage staff expenditure & 2 & 0.097 & 0.012 & 0.000 & 0.000 & 0.000 & 0.000 \\
Log investment & 2 & 0.084 & 0.049 & 0.085 & 0.900 & 1.000 & 0.891 \\
Log sales (2nd measure) & 2 & 0.063 & 0.012 & 0.000 & 0.200 & 0.000 & 0.000 \\
Log added value per worker & 2 & 0.001 & 0.012 & 0.931 & 1.000 & 1.000 & 1.000 \\
\hline
\end{tabular}

Note: The table presents the main results and multiple-test-adjusted p-values using different methodologies using the algorithm of Jones et al. (2019). The first column indicates the outcome variable; the second indicates the year of the applicable difference-in-difference coefficient (e.g. ' 1 ' denotes the first year after the FIG subsidy is attributed); the third, fourth and fifth columns indicate the coefficient, standard error and $p$ values from the main analysis; and the last three columns indicate the $p$-values computed under different approaches towards multiple testing: Westfall \& Young (1993), Bonferroni-Holm and Sidak-Holm adjusted p-values. 
Table A.7. Multiple testing analysis $1 / 2$

\begin{tabular}{lccccccc}
\hline Outcome & Family & Coef & Std Err & p-value & pwyoung & pbonf & psidak \\
\hline Log sales & 3 & 0.080 & 0.019 & 0.000 & 0.233 & 0.001 & 0.001 \\
Log employment & 3 & 0.047 & 0.012 & 0.000 & 0.233 & 0.003 & 0.003 \\
Log sales per worker & 3 & 0.033 & 0.017 & 0.054 & 0.900 & 1.000 & 0.803 \\
Export status & 3 & 0.018 & 0.008 & 0.028 & 0.767 & 0.851 & 0.578 \\
Log exports & 3 & 0.151 & 0.081 & 0.061 & 0.900 & 1.000 & 0.831 \\
Log profits & 3 & 0.078 & 0.045 & 0.087 & 0.933 & 1.000 & 0.891 \\
Profit ratio & 3 & -0.111 & 0.159 & 0.485 & 1.000 & 1.000 & 1.000 \\
Log taxes & 3 & -0.006 & 0.042 & 0.878 & 1.000 & 1.000 & 1.000 \\
Log non wage staff expenditure & 3 & 0.075 & 0.014 & 0.000 & 0.167 & 0.000 & 0.000 \\
Log investment & 3 & 0.008 & 0.052 & 0.877 & 1.000 & 1.000 & 1.000 \\
Log sales (2nd measure) & 3 & 0.076 & 0.016 & 0.000 & 0.233 & 0.000 & 0.000 \\
Log added value per worker & 3 & 0.019 & 0.013 & 0.148 & 0.967 & 1.000 & 0.944 \\
Log sales & 4 & 0.080 & 0.021 & 0.000 & 0.267 & 0.005 & 0.005 \\
Log employment & 4 & 0.033 & 0.014 & 0.019 & 0.700 & 0.609 & 0.459 \\
Log sales per worker & 4 & 0.046 & 0.018 & 0.012 & 0.600 & 0.404 & 0.334 \\
Export status & 4 & 0.023 & 0.009 & 0.007 & 0.500 & 0.243 & 0.216 \\
Log exports & 4 & 0.145 & 0.088 & 0.098 & 0.933 & 1.000 & 0.895 \\
Log profits & 4 & 0.086 & 0.049 & 0.079 & 0.900 & 1.000 & 0.883 \\
Profit ratio & 4 & 0.078 & 0.046 & 0.088 & 0.933 & 1.000 & 0.891 \\
Log taxes & 4 & -0.007 & 0.044 & 0.869 & 1.000 & 1.000 & 1.000 \\
Log non wage staff expenditure & 4 & 0.058 & 0.016 & 0.000 & 0.267 & 0.009 & 0.009 \\
Log investment & 4 & 0.042 & 0.055 & 0.447 & 1.000 & 1.000 & 1.000 \\
Log sales (2nd measure) & 4 & 0.081 & 0.018 & 0.000 & 0.233 & 0.000 & 0.000 \\
Log added value per worker & 4 & 0.028 & 0.016 & 0.075 & 0.900 & 1.000 & 0.879 \\
\hline
\end{tabular}

Note: The table presents the main results and multiple-test-adjusted p-values using different methodologies using the algorithm of Jones et al. (2019). The first column indicates the outcome variable; the second indicates the year of the applicable difference-in-difference coefficient (e.g. ' 3 ' denotes the third year after the FIG subsidy is attributed); the third, fourth and fifth columns indicate the coefficient, standard error and pvalues from the main analysis; and the last three columns indicate the $p$-values computed under different approaches towards multiple testing: Westfall \& Young (1993), Bonferroni-Holm and Sidak-Holm adjusted p-values. 
Table A.8. Descriptive statistics, All successful applicants, Application year (1/2)

\begin{tabular}{|c|c|c|c|c|c|c|}
\hline & \multicolumn{2}{|c|}{ (1) } & \multicolumn{2}{|c|}{ (2) } & \multicolumn{2}{|c|}{ (3) } \\
\hline & \multicolumn{2}{|c|}{ Approved } & \multicolumn{2}{|c|}{ Rejected } & \multicolumn{2}{|c|}{ Difference } \\
\hline & Mean & SD & Mean & SD & $b$ & $\mathrm{t}$ \\
\hline Total sales & 19.49 & 138.94 & 11.65 & 71.09 & -7.84 & $(-1.88)$ \\
\hline Number of employees & 111.66 & 480.61 & 62.52 & 222.63 & $-49.13^{* * *}$ & $(-3.65)$ \\
\hline Capital equity & 4.01 & 40.99 & 6.43 & 107.96 & 2.42 & $(0.46)$ \\
\hline Domestic private share & 89.49 & 29.79 & 90.14 & 28.85 & 0.65 & $(0.44)$ \\
\hline Foreign share & 6.57 & 23.83 & 6.76 & 23.99 & 0.19 & $(0.16)$ \\
\hline Firm age & 21.35 & 22.77 & 17.36 & 12.27 & $-3.99^{\star * \star}$ & $(-5.64)$ \\
\hline Gross added value & 5.37 & 41.36 & 3.14 & 31.92 & -2.23 & $(-1.29)$ \\
\hline Total sales (2) & 19.76 & 112.57 & 10.89 & 74.75 & $-8.87^{\star}$ & $(-2.13)$ \\
\hline Investment & 1.44 & 21.80 & 1.11 & 16.71 & -0.33 & $(-0.36)$ \\
\hline Profits & 0.88 & 13.68 & 0.56 & 11.28 & -0.32 & $(-0.53)$ \\
\hline Income taxes paid & 0.28 & 3.73 & 0.30 & 4.40 & 0.02 & $(0.09)$ \\
\hline Non-salary staff expenditure & 0.66 & 4.74 & 0.30 & 1.53 & $-0.36^{* *}$ & $(-3.24)$ \\
\hline Training expenditure & 4.98 & 30.49 & 6.11 & 65.36 & 1.13 & $(0.22)$ \\
\hline Food & 0.05 & & 0.04 & & -0.01 & $(-0.86)$ \\
\hline Clothing & 0.04 & & 0.05 & & 0.02 & $(1.40)$ \\
\hline Ceramics & 0.04 & & 0.03 & & -0.01 & $(-1.07)$ \\
\hline Molds & 0.07 & & 0.06 & & -0.01 & $(-0.41)$ \\
\hline Construction & 0.04 & & 0.07 & & 0.02 & $(1.91)$ \\
\hline Electric appliances & 0.04 & & 0.05 & & 0.01 & $(0.60)$ \\
\hline Wholesale & 0.11 & & 0.09 & & -0.03 & $(-1.76)$ \\
\hline Retail & 0.06 & & 0.09 & & $0.03^{*}$ & $(2.07)$ \\
\hline Transport & 0.03 & & 0.03 & & -0.00 & $(-0.37)$ \\
\hline North region & 0.46 & & 0.52 & & $0.06^{*}$ & $(2.41)$ \\
\hline Centre region & 0.33 & & 0.19 & & $-0.14^{\star \star *}$ & $(-6.59)$ \\
\hline Lisbon region & 0.13 & & 0.15 & & 0.02 & $(1.08)$ \\
\hline Exports & 9.90 & 54.07 & 3.65 & 8.68 & $-6.24^{\star * *}$ & $(-4.02)$ \\
\hline N. of products exported & 23.43 & 50.31 & 14.07 & 26.58 & $-9.36^{\star * \star}$ & $(-3.75)$ \\
\hline N. of countries exported to & 8.17 & 10.82 & 5.74 & 6.80 & $-2.44^{\star * *}$ & $(-3.98)$ \\
\hline Observations & 3581 & & 423 & & 4004 & \\
\hline
\end{tabular}

Note: See notes to Table 1. All firms were approved in their applications. Rejected are firms that decided not to accept the offer. 
Table A.9. Descriptive statistics, All successful applicants, Application year (2/2)

\begin{tabular}{|c|c|c|c|c|c|c|}
\hline & \multicolumn{2}{|c|}{ (1) } & \multicolumn{2}{|c|}{ (2) } & \multicolumn{2}{|c|}{ (3) } \\
\hline & \multicolumn{2}{|c|}{ Accepted by firm } & \multicolumn{2}{|c|}{ Rejected by firm } & \multicolumn{2}{|c|}{ Difference } \\
\hline & Mean & SD & Mean & SD & $b$ & $\mathrm{t}$ \\
\hline Employees' female share & 0.36 & 0.28 & 0.36 & 0.28 & 0.00 & $(0.06)$ \\
\hline Employees' age & 38.35 & 4.73 & 38.16 & 4.76 & -0.20 & $(-0.80)$ \\
\hline Employees' tenure & 7.58 & 5.15 & 6.81 & 4.58 & $-0.76^{* *}$ & $(-3.20)$ \\
\hline Employees' open-ended contract & 0.69 & 0.26 & 0.68 & 0.27 & -0.01 & $(-0.67)$ \\
\hline Employees' schooling & 9.04 & 2.29 & 9.19 & 2.47 & 0.15 & $(1.19)$ \\
\hline Employees' base wage & 810.85 & 421.55 & 801.11 & 453.12 & -9.74 & $(-0.42)$ \\
\hline Employees' total wage & 952.32 & 473.77 & 933.16 & 501.48 & -19.15 & $(-0.75)$ \\
\hline Training funding requested & 96.80 & 278.35 & 68.55 & 82.81 & $-28.26^{* * *}$ & $(-4.59)$ \\
\hline Training funding approved & 27.79 & 35.77 & 23.15 & 21.46 & $-4.65^{\star * *}$ & $(-3.86)$ \\
\hline Subsidy (wagebill) rate & 1.25 & 5.48 & 1.48 & 2.37 & 0.22 & $(1.52)$ \\
\hline Workers to train request & 130.57 & 189.92 & 156.40 & 216.18 & $25.83^{*}$ & (2.35) \\
\hline Workers to train approved & 111.81 & 140.05 & 0.00 & 0.00 & $-111.81^{* * *}$ & $(-47.77)$ \\
\hline Training hours request & 3955.13 & 6690.82 & 4514.11 & 5483.69 & 558.98 & $(1.93)$ \\
\hline Training hours approved & 3371.67 & 4173.90 & 0.00 & 0.00 & $-3371.67^{\star * *}$ & $(-48.34)$ \\
\hline Duration of training (months) & 11.39 & 6.79 & 8.58 & 3.83 & $-2.82^{\star \star \star}$ & $(-12.90)$ \\
\hline Training hours & 1149.19 & 5589.43 & 825.90 & 3662.64 & -323.29 & $(-0.98)$ \\
\hline Non-catalogue training & 441.58 & 4941.42 & 122.78 & 732.22 & $-318.80^{*}$ & $(-2.20)$ \\
\hline Externals-provided training & 674.97 & 2290.85 & 633.14 & 2973.78 & -41.83 & $(-0.17)$ \\
\hline Working-time training & 965.94 & 5497.24 & 636.55 & 3460.37 & -329.39 & $(-1.04)$ \\
\hline Workers under training & 22.64 & 132.05 & 14.63 & 79.34 & -8.01 & $(-1.80)$ \\
\hline Observations & 3581 & & 423 & & 4004 & \\
\hline
\end{tabular}

Note: See notes to Table 2. All firms were approved in their applications. Rejected are firms that decided not to accept the offer. 


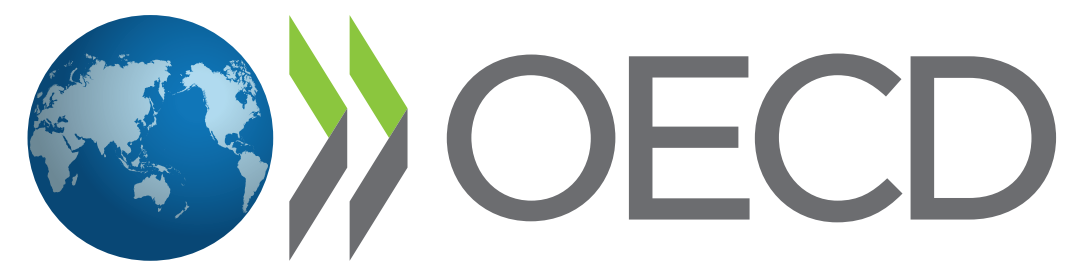

BETTER POLICIES FOR BETTER LIVES 